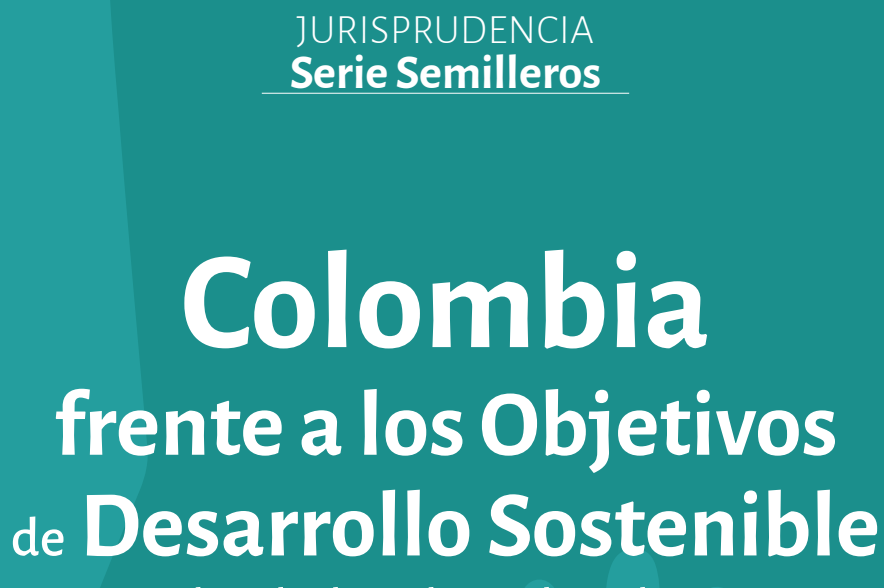

Retos desde los derechos humanos

María Lucía Torres-Villarreal

Paola Marcela Iregui-Parra

-Editorasacadémicas-

Fundación

Hanns

Seidel 

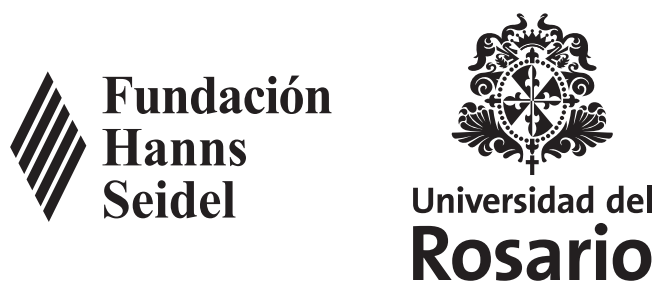


\section{Colombia frente a los Objetivos de Desarrollo Sostenible}




\title{
Colombia frente a los Objetivos de Desarrollo Sostenible: Retos desde los derechos humanos
}

\section{Resumen}

Próximos a cumplir el primer quinquenio de los quince años previstos para alcanzar el máximo resultado en la realización de los Objetivos de Desarrollo Sostenible (oDs), la Universidad del Rosario, en cabeza del Observatorio Legislativo y el Grupo de Investigación en Derechos Humanos, en asociación con la Fundación Hanns Seidel, ha brindado el espacio propicio de investigación para los estudiantes interesados en reflexionar, discutir y proponer trabajos académicos relacionados con los ods. Así, este libro recoge las ponencias de los estudiantes ganadores del ix Concurso de Semilleros de Investigación, en procura de fomentar espacios académicos de fortalecimiento de la democracia, la institucionalidad y los derechos humanos, dentro de los cuales este concurso se destaca no solo por su perdurabilidad en el tiempo, al atender temas coyunturales para el país, sino por aportar valor a la investigación como herramienta de cambio social y como instrumento pedagógico de enseñanza que debe fomentarse en la educación superior.

Palabras clave: Objetivos de Desarrollo Sostenible, derechos humanos, agua, salud, cultura.

\section{Colombia in the Face of Sustainable Development Goals: Challenges from the Perspective of Human Rights}

\begin{abstract}
Close to the end of the first five years of the fifteen-year period planned to get maximum results in the achievement of the Sustainable Development Goals (sDGs), the Universidad del Rosario - under the leadership of the Legislative Observatory and the Human Rights Research Group, in partnership with the Hanns Seidel Foundation-has opened up an appropriate research space for students interested in reflecting, discussing, and proposing academic works related to the sDGs. Thus, this book gathers the papers of a group of students who were the winners of the Ix Research Incubator Contest, which sought to foster academic spaces for the strengthening of democracy, institutionality, and human rights; this contest stands out not only for its durability in time, dealing with relevant issues for the country, but also for its importance of giving value to research as a tool of social change and a pedagogical instrument that should be promoted in higher education.
\end{abstract}

Key words: Sustainable Development Goals, human rights, water, health, culture.

Citación sugerida: Torres-Villarreal, M. L. e Iregui-Parra, P. M. (Eds.). (2019). Colombia frente a los Objetivos de Desarrollo Sostenible: Retos desde los derechos humanos. Bogotá: Editorial Universidad del Rosario. https://doi.org/10.12804/tj9789587843507 


\title{
Colombia frente a los Objetivos de Desarrollo Sostenible: Retos desde los derechos humanos
}

\author{
María Lucía Torres-Villarreal \\ Paola Marcela Iregui-Parra \\ -Editoras académicas-
}


Colombia frente a los Objetivos de Desarrollo Sostenible: Retos desde los derechos humanos / María Lucía Torres-Villarreal, Paola Marcela Iregui-Parra, editoras académicas. Bogotá: Editorial Universidad del Rosario, Fundación Hanns Seidel, 2019.

\section{XIII, 125 páginas.}

Incluye referencias bibliográficas.

1. Derecho internacional público 2. Derechos humanos 3. Objetivos de Desarrollo Sostenible 4. Derechos civiles I. Torres-Villarreal, María Lucía, editora académica II. IreguiParra, Paola Marcela, editora académica III. Universidad del Rosario. IV.Título.

$$
341.481026
$$

$$
\text { SCDD } 20
$$

Catalogación en la fuente - Universidad del Rosario. CRAI

Hecho el depósito legal que marca el Decreto 460 de 1995

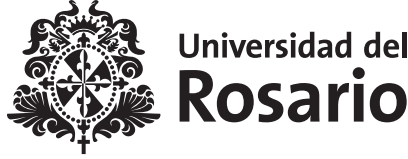

Jurisprudencia

(C) Editorial Universidad del Rosario

(C) Universidad del Rosario

(C) Fundación Hanns Seidel

(C) Varios autores

(C) María Lucía Torres-Villarreal y Paola Marcela Iregui-Parra, por la Presentación

Editorial Universidad del Rosario Carrera 7 n. ${ }^{\circ}$ 12B-41, of. 501

Tel: 297 0200, ext. 3112

editorial.urosario.edu.co

\section{Fundación Hanns Seidel}

\author{
Primera edición: Bogotá D. C., noviembre \\ de 2019 \\ ISBN: 978-958-784-349-1 (impreso) \\ ISBN: 978-958-784-350-7 (ePub) \\ ISBN: 978-958-784-351-4 (PDF) \\ https://doi.org/10.12804/tj9789587843507 \\ Coordinación editorial: \\ Editorial Universidad del Rosario \\ Corrección de estilo: Ella Suárez \\ Diseño de cubierta y diagramación: \\ Andrea Julieth Castellanos \\ Impresión: Xpress. Estudio Gráfico y Digital SAS \\ Impreso y hecho en Colombia \\ Printed and made in Colombia
}

Los conceptos y opiniones de esta obra son de exclusiva responsabilidad de sus autores y no comprometen a la universidad ni sus políticas institucionales.

El contenido de este libro fue sometido al proceso de evaluación de pares, para garantizar los altos estándares académicos. Para conocer las políticas completas visitar: editorial.urosario.edu.co

Todos los derechos reservados. Esta obra no puede ser reproducida sin el permiso previo escrito de los editores. 


\section{Contenido}

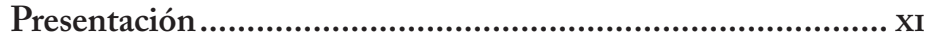

La contribución del Grupo de Acciones Públicas

de la Universidad del Rosario a los Objetivos de Desarrollo

Sostenible: un análisis del caso "viche del Pacífico" ..................... 1

Juan Manuel Montoya

Esteban Guerrero

María Lucía Cruz Galindo

La influencia de la telesalud en la ginecobstetricia

y su relación con los Objetivos de Desarrollo

Sostenible en salud .35

Daniel Castañeda Granados

Erika Milena Moscoso

Exigibilidad del derecho a la participación de las mujeres campesinas de Cerrito (Santander) en la delimitación del páramo del Almorzadero: estudio de caso

Angie Carolina Herrera Ramirez

Maria Victoria Jaimes Becerra

Carolina Isabel Montes Perea

Ivone Alejandra Prada Torres 


\section{Presentación}

Los Objetivos de Desarrollo Sostenible (oDs) corresponden a diecisiete propósitos y a una serie de metas, aprobados por la comunidad internacional en el marco de la Asamblea General de la Organización de las Naciones Unidas en septiembre de 2015, como una continuación de la agenda prevista para los Objetivos de Desarrollo del Milenio. Estos propósitos abarcan, de manera transversal, todas las áreas relevantes y vigentes para alcanzar condiciones de desarrollo universal, incluyendo la atención urgente de los retos impuestos por el cambio climático, la protección del medio ambiente con especial enfoque en la vida y los ecosistemas tanto terrestres como submarinos, el acceso al agua potable y a educación de calidad, la eliminación de la pobreza y la reducción del hambre, el acceso al trabajo decente, la igualdad material de género, así como aspectos relacionados con la paz y la justicia internacional.

Estando próximos a cumplir el primer quinquenio de los quince años previstos para alcanzar el máximo resultado en la realización de estos oDs, la Universidad del Rosario, en cabeza del Observatorio Legislativo y el Grupo de Investigación en Derechos Humanos, en asociación con la Fundación Hanns 
Seidel, organizó el ix Concurso de Semilleros de Investigación, titulado Colombia frente a los Objetivos de Desarrollo Sostenible: retos desde los derechos humanos. El objetivo de este concurso fue brindar el espacio propicio de investigación para los estudiantes interesados en reflexionar, discutir y proponer trabajos académicos relacionados con los oDs, partiendo del entendido de la investigación como herramienta idónea para generar conocimiento y fortalecimiento de habilidades en los estudiantes, como la capacidad de análisis crítico, de creatividad y de interrelación de temáticas, indispensables para su futuro profesional.

En esta ocasión, recibimos 45 ponencias de estudiantes y grupos de todo el país, de las cuales 33 fueron aportadas por instituciones regionales y las 12 restantes procedieron de Bogotá. Es preciso destacar la consistente participación de las regiones en el concurso, evidenciado no solo en la amplia contribución de este año, sino también en la recepción que ha tenido la invitación en vigencias anteriores. Indudablemente, la acogida regional del Concurso de Semilleros de Investigación demuestra el compromiso nacional de los estudiantes provenientes de diferentes sectores del país con asuntos de envergadura internacional que inciden directamente en el bienestar de Colombia, quienes visibilizaron especialmente los casos y los escenarios de desarrollo en las regiones, así como los que requieren especial atención gubernamental, para con ello contribuir realmente en la materialización de los objetivos acordados en el ámbito global y que atañen directamente al Estado colombiano.

Conforme a lo anterior, dentro de las 45 iniciativas de investigación presentadas, los pares evaluadores (profesores y expertos de alto perfil académico y profesional) seleccionaron 
veintiún ponencias para ser expuestas en las rondas orales de sustentación de las ponencias y en la presentación final, las cuales se llevaron a cabo el 29 y el 30 de abril de 2019. La parte oral del concurso se organizó en mesas temáticas compuestas por tres jurados docentes e investigadores, en las que los ponentes tuvieron la oportunidad de exponer sus investigaciones de manera clara y coherente, atendiendo a los interrogantes de los jurados y de los asistentes. Posteriormente, las presentaciones que obtuvieron los puntajes más altos en sus mesas respectivas expusieron sus trabajos en la ronda final, siguiendo el mismo formato de las rondas orales preliminares. Cabe señalar que la etapa oral del concurso se llevó a cabo en el marco del foro Retos Actuales y Futuros de la Migración: Una Mirada desde las Instituciones, que contó con la participación de especialistas en migraciones, donde se analizaron las implicaciones a corto, mediano y largo plazo de este fenómeno. A este asistieron estudiantes y profesores de universidades a lo largo del país, incluyendo los participantes del Concurso lo cual favoreció el intercambio académico.

En consecuencia, de los puntajes obtenidos por parte de los jurados evaluadores se dictaminó como ganadora del primer lugar la ponencia titulada "La contribución del Grupo de Acciones Públicas de la Universidad del Rosario a los Objetivos de Desarrollo Sostenible: un análisis del Caso Viche del Pacífico", a cargo de la Clínica Jurídica Grupo de Acciones Públicas de la Universidad Rosario. En segundo lugar, se escogió la ponencia titulada "La influencia de la telesalud en la ginecobstetricia y su relación con los Objetivos de Desarrollo Sostenible en salud", desarrollada por estudiantes de pregrado de la Facultad de Jurisprudencia 
de la Universidad del Rosario; por último, se seleccionó la iniciativa del Semillero Vida, Ciencia y Derechos $\mathrm{Hu}^{-}$ manos de la Escuela de Derecho y Ciencia Política, de la Universidad Industrial de Santander, denominada "Estudio de caso: exigibilidad del derecho a la participación de las mujeres Cerrito (Santander) en la delimitación del páramo del Almorzadero".

Las ponencias ganadoras incitaron la discusión sobre sectores específicos, relacionados con casos y lugares concretos en el territorio colombiano, que afectan varios de los obs que son prioritarios ante el impacto creciente y abrumador del cambio climático, por una parte, y el nuevo auge respecto a los debates alrededor de la necesidad imperante de conseguir igualdad y justicia real en términos socioeconómicos, por otra. En efecto, las investigaciones ganadoras abordan temáticas en materia de garantía de derechos humanos, la materialización del derecho a la salud, el reconocimiento del aporte indispensable de las mujeres en la consecución de una sociedad democrática y pacífica y la protección de los valiosos recursos acuíferos - como los páramos- que privilegian a Colombia en la región y el mundo.

Para finalizar, queremos agradecer el constante apoyo que hemos recibido de la Fundación Hanns Seidel en la realización del Concurso de Semilleros de Investigación y, con ello, en el patrocinio de la investigación de calidad en ciencias humanas y sociales alrededor del país, sobre aspectos que contribuyen al fortalecimiento de la participación ciudadana, al respeto de los derechos humanos y al acondicionamiento básico y necesario para el disfrute soberano de la democracia, que se deben predicar del Estado social de derecho. Este año celebramos el décimo aniversario de la estrecha relación de 
cooperación entre la fundación y la universidad, en procura de crear espacios académicos de fortalecimiento de la democracia, la institucionalidad y los derechos humanos, dentro de los cuales este concurso se destaca no solo por su perdurabilidad en el tiempo, atendiendo temas coyunturales para el país, sino por la pertinencia de dar valor a la investigación como herramienta de cambio social y como instrumento pedagógico de enseñanza que debe fomentarse en la educación superior.

\author{
María Lucía Torres-Villarreal \\ Directora del Observatorio Legislativo \\ Grupo de Investigación en Derechos Humanos \\ Facultad de Jurisprudencia \\ Paola Marcela Iregui-Parra \\ Profesora de carrera académica \\ Grupo de Investigación en Derechos Humanos \\ Facultad de Jurisprudencia
}




\title{
La contribución del Grupo de Acciones Públicas de la Universidad del Rosario a los Objetivos de Desarrollo Sostenible: un análisis del caso "viche del Pacífico"
}

\author{
Juan Manuel Montoya* \\ Esteban Guerrero \\ María Lucía Cruz Galindo
}

Resumen: La educación legal clínica, para el caso del Grupo de Acciones Públicas, constituye un verdadero escenario que habilita, dinamiza y posibilita el cumplimiento de los

* Estudiante de Jurisprudencia y Ciencia Política y Gobierno de la Universidad del Rosario. Miembro activo del Grupo de Acciones Públicas de la misma casa de estudios. Correo electrónico: juanm.montoya@urosario.edu.co

** Politólogo y estudiante de Jurisprudencia de la Universidad del Rosario. Miembro activo del Grupo de Acciones Públicas de la misma casa de estudios. Correo electrónico: esteban.guerreroa@urosario.edu.co

*** Estudiante de décimo semestre de la Universidad del Rosario. Miembro activo del Grupo de Acciones Públicas de la misma casa de estudios. Correo electrónico:marial.cruz@urosario.edu.co 
Objetivos de Desarrollo Sostenible a través de la puesta en marcha de acciones y estrategias tendientes a la defensa del interés público. Así, el análisis del caso "viche del Pacífico" permite sustentar tal aserto, en la medida en que el despliegue de esfuerzos encaminados a la protección de conocimientos y saberes ancestrales o tradicionales de las comunidades negras, que representan un activo cultural y económico —así como una manifestación de su identidad—, se acompasa con el cumplimiento de Objetivos de Desarrollo Sostenible y la Agenda 2030, lo que implica que dicho cometido no es solo tarea del Estado, sino también de plataformas que, desde la academia, contribuyen para tal fin.

Palabras clave: educación legal clínica, comunidades negras, identidad cultural, viche del Pacífico, Objetivos de Desarrollo Sostenible, interés público.

\section{Introducción}

Los Objetivos de Desarrollo Sostenible (oDs), comprendidos en la Agenda 2030 para el desarrollo y herederos tanto de los éxitos como de los desafíos y metas inconclusas de los Objetivos de Desarrollo del Milenio, trazan una nueva senda que pretende integrar el crecimiento económico, el bienestar social y la protección del medio ambiente. Se erigen también como una respuesta a las discusiones sobre el desarrollo que han paralizado esfuerzos colaborativos y derivado en resultados exiguos e incipientes. Al respecto, se ha indicado que "las tendencias mundiales dominantes en la economía y en la sociedad exacerban las contradicciones de un estilo de desarrollo que se ha vuelto insostenible" 
(Comisión Económica para América Latina y el Caribe [Cepal],2016b, p. 9). Esas contradicciones son inocultables: una desigualdad en aumento, la agudización de la crisis ambiental y la profundización de desequilibrios económicos y sociales que exigen insoslayables esfuerzos de la comunidad internacional.

Unos de los innegables escollos para el cumplimiento de los oDs son, por un lado, el financiamiento de los diecisiete objetivos planteados (Girón, 2016) y, por otro, la ausencia de obligatoriedad, por cuanto no se trata de un instrumento jurídicamente vinculante para los Estados. De ahí que corresponda a cada Estado la adopción de medidas del orden nacional tendientes al cumplimiento de las metas que subyacen a cada objetivo.

La suma de esfuerzos, voluntades y compromisos nacionales, regionales e internacionales representa, sin duda alguna, un importante paso en el logro de estos objetivos, por lo que es dable sostener que el éxito de aquellos estriba en la acción colectiva y coordinada entre Estados, la sociedad civil y la academia. Nada obsta para que distintos actores, pedagogías y apuestas desde la educación contribuyan a su consecución.

Así, la promoción del bienestar social, la superación de la pobreza y la defensa del medio ambiente - por mencionar algunos - no han de entenderse como responsabilidades exclusivas del Estado. Desde distintos escenarios, como es el caso del Grupo de Acciones Públicas (GAP), a través del modelo de educación legal clínica, se coadyuva la realización de acciones encaminadas a la defensa del interés público, la salvaguardia de los derechos humanos y la concreción de los cometidos estatales. Desde estos espacios de formación 
práctico-académica se proveen las herramientas para atender las necesidades legales de las comunidades menos favorecidas, del medio ambiente y de la colectividad, para lo cual se dedican ingentes esfuerzos en la incidencia en políticas públicas, asuntos legislativos y se despliega el trabajo persuasivo y estratégico ante las altas cortes (Torres Villarreal, 2013).

Estos principios orientadores de la actividad y gestión del GAP animan a resolver el siguiente interrogante: ¿cuál es la relación de la educación legal clínica y su apuesta pedagógica con el cumplimiento o avance en los oDs u objetivos mundiales?

Desde ahora, anticipamos que las líneas en que se funda este capítulo pretenden sustentar el aserto según el cual el trabajo clínico, a partir del caso del GAP, contribuye a cumplir los ods. ${ }^{1}$ Para evidenciarlo, se acudirá al análisis del asunto "viche del Pacífico", uno de los más recientes casos de impacto nacional en el que el GAP participa y en cuyas actuaciones se revela un vínculo inescindible con los objetivos de fin de la pobreza, hambre cero, salud y bienestar, reducción de las desigualdades y producción y consumo responsables.

\section{Metodología}

Desde el punto de vista metodológico, este capítulo se nutre de la revisión teórica sobre la educación legal clínica, cuyas líneas se enriquecen, además de las experiencias que resultan de distintos casos de impacto local y nacional, de aquellos en los que el GAP ha participado. En lo tocante al "viche del Pacífico”, el conocimiento del caso se ha profundizado con

1 A efectos del caso de estudio, esta conclusión comprende la contribución en cinco objetivos. 
los relatos y testimonios de los sabedores tradicionales, al igual que de las organizaciones con un interés directo en la protección de esta manifestación de la identidad cultural de las comunidades negras.

A dichas narrativas se yuxtaponen las discusiones en que el GAP se ha involucrado, escenarios donde ha tenido la oportunidad de dialogar con las distintas entidades y corporaciones del Estado, organizaciones sin ánimo de lucro y colectivos que reivindican la defensa del conocimiento tradicional y las expresiones culturales. Las perspectivas disímiles y ambivalentes, algunas de las cuales reflejan la relación entre lo público-privado, enriquecen el debate sobre el reconocimiento del viche del Pacifico como un activo inherente a la cultura de las comunidades negras. A partir de lo anterior, se analizan aquellas estrategias adoptadas por el GAP que circundan el caso del viche. El ámbito geográfico del trabajo se concentra en el estudio de un caso fuertemente asociado con el litoral pacífico colombiano, pero con un palmario impacto nacional.

En aras de un análisis comprensivo y consolidado del tema, se aborda: 1) la relación entre los ods y las clínicas jurídicas; 2) el viche del Pacífico, las comunidades negras y su protección en el ordenamiento jurídico colombiano; 3) las acciones adelantadas por el GAP en el caso en comento; 4) la relación entre el caso de estudio y los ods, y 5) seguido de lo cual se expondrán las conclusiones a que haya lugar. 


\section{Las clínicas jurídicas y su contribución al cumplimiento de los Objetivos de Desarrollo Sostenible}

En la Conferencia de las Naciones Unidas sobre el Desarrollo Sostenible de 2012, realizada en Río de Janeiro, se pactaron diecisiete objetivos y 169 metas integradas con base en tres ejes críticos: ambiental, político y económico. Estos derroteros se encuentran todos interrelacionados, en aras de que el cumplimiento de uno se traduzca en avances de los demás, pues es impensable que para promover el desarrollo se estimulen prácticas en perjuicio del ambiente, por ejemplo. Los objetivos sobre los cuales se funda la Agenda 2030 para el desarrollo confluyen en la pretensión - y deuda histórica - de erradicar la pobreza, cercenar las profundas desigualdades, estimular el crecimiento y asegurar, entre otros, la protección de los recursos y el medio natural.

Los oDs constituyen un parámetro mundial para conseguir que los Estados, el sector privado o empresas, la academia y demás actores de la sociedad civil asuman el compromiso de garantizar condiciones de vida digna a toda la población, respetando sus derechos y propendiendo al cuidado y sostenibilidad de su entorno. Estos desafíos políticos, económicos y ambientales representan un espacio de transformación mundial que permitirá el mejoramiento de la calidad de vida de todas las personas y, sobre todo, la conservación del ambiente (Programa de las Naciones Unidas para el Desarrollo, 2011).

A partir de este panorama, es dable considerar que las clínicas jurídicas, como engranaje de la acción colectiva, representan escenarios que abogan desde la academia por el cumplimiento de los ods. Esta apuesta pedagógica, surgida en Estados Unidos a finales del siglo xIX y principios del siglo Xx 
(Witker, 2007), se ha concebido como una plataforma edificada sobre el ánimo de crear conciencia e impacto social en, y desde, los estudiantes de derecho, al poner en práctica sus conocimientos teóricos enseñados en las aulas de clase - lo cual se asemeja a las facultades de medicina, donde los estudiantes antes de graduarse debían realizar prácticas obligatorias de servicios gratuitos a la comunidad- (Almanza Iglesia, 2010). En ese sentido, el objeto de las clínicas ha sido no solo la formación de abogados, sino ser un espacio de protección y garantía de derechos de personas y comunidades que históricamente han sido marginadas, logrando avanzar en la superación del panorama de desigualdad e injusticia al que se ven expuestos.

En consecuencia, este modelo repercutió en algunos países de Latinoamérica bajo el Proyecto sobre Derecho y Desarrollo, apoyado por la Fundación Ford, junto con la Agencia para el Desarrollo Internacional de Estados Unidos (González, 2004), en procura de fomentar la protección de las libertades y garantías fundamentales, superar dificultades sociales y soslayar vulneraciones sistemáticas de los derechos en la región.

En el caso colombiano, hace veinte años nace la primera clínica jurídica: el GAP de la Universidad del Rosario. Su configuración se erige como respuesta a un contexto histórico que marcó la dinámica de protección de los derechos en Colombia y como referente académico en materia de educación legal clínica, al igual que como espacio pedagógico que promueve la acción jurídica y la incidencia social a través de la puesta en marcha de distintos instrumentos que provee el ordenamiento jurídico. A través del litigio estratégico, el GAP ha llevado a cabo acciones judiciales, incidido en medios 
de comunicación y altas cortes y realizado talleres pedagógicos o street law, procurando con ellos la protección de los derechos de las comunidades (Londoño-Toro et al., 2009).

La educación legal clínica, para el caso del GAP, constituye, además de un eje articulador, un verdadero escenario que habilita, dinamiza y posibilita el cumplimiento de los oDs a través de la puesta en marcha de acciones y estrategias tendientes a la defensa del interés público. Así, el análisis del caso "viche del Pacífico" permite respaldar tal aserto, en la medida en que el despliegue de esfuerzos encaminados a la protección de conocimientos y saberes ancestrales o tradicionales de las comunidades negras, que representan un activo cultural y económico - así como una manifestación de su identidad-, se acompasa con el cumplimiento de oDs y la Agenda 2030, lo que implica que dicho cometido no es solo tarea del Estado, sino también de plataformas que, desde la Academia, contribuyen a tal fin.

\section{Protección a las comunidades negras y el viche del Pacífico}

Ante la invitación de un aliado estratégico, el GAP decidió vincularse a un proceso en el cual se pusieron en conflicto los derechos e intereses de las comunidades negras frente a la legislación y la regulación normativa que existe respecto de sus conocimientos y saberes ancestrales, en especial sobre el destilado viche del Pacífico. Este conflicto, por explicar en adelante, impone ineludiblemente una revisión sobre las normas que protegen la identidad cultural de las comunidades negras y las características del bebedizo como expresión susceptible de protección. 
Sin embargo, es importante hacer una revisión que denote la evolución que normativamente ha tenido el trato dado a las comunidades étnicas, en especial las comunidades negras, antes de explicar las características propias del caso llevado dentro de la clínica. En ese sentido, este apartado recuenta brevemente la evolución en materia de derechos que las comunidades negras han vivido a raíz de nuestra Constitución de 1991.

Para ello, es importante empezar por revisar la Ley 70 de 1993, con arreglo a la cual se define a las comunidades negras como "el conjunto de familias de ascendencia afrocolombiana que poseen una cultura propia, comparten una historia y tienen sus propias tradiciones y costumbres dentro de la relación campo-pobladores, que revelan y conservan conciencia de identidad que las distinguen de otros grupos étnicos" (artículo 2). Este elemento es de una importancia fundamental, toda vez que a partir de esta definición es que debe comprenderse que los productos y actividades que rodean el viche del Pacífico constituyen un elemento esencial y característico de las comunidades negras y que, por tanto, debe ser objeto de las garantías normativas existentes.

Pertinente es señalar que la Corte Constitucional ha expuesto de forma reiterada la importancia de proteger a las comunidades étnicas en virtud de su condición de sujeto de especial protección constitucional. Al respecto, es posible leer:

Esta Corporación ha reconocido la importancia en el reconocimiento y protección de los derechos de las comunidades étnicas en general y los grupos humanos poseedores de una cultura diferente a la mayoritaria, como 
medio para garantizar su subsistencia. Lo anterior, toda vez que se encuentran en una situación de vulnerabilidad debido, entre otras razones, a: (i) la existencia de patrones bistóricos de discriminación que les impiden el pleno ejercicio de sus derechos y su cultura; (ii) la presión ejercida sobre sus territorios, su forma de ver el mundo, su organización social, sus modos de producción y su concepción sobre el desarrollo, originada en la explotación de los recursos naturales y la formulación de proyectos de desarrollo de diversa naturaleza en sus territorios ancestrales; (iii) el grave impacto que el conficto armado ha generado en su modo de vida, reflejado en desplazamiento forzado y afectaciones de especial gravedad a sus territorios ancestrales, usados como corredores estratégicos o escenarios directos del conflicto; y (iv) la marginación económica, politica, geográfica y social que, por regla general, enfrentan como grupos minoritarios. (Corte Constitucional, sentencia T-414 de 2015, p. 26; cursivas de los autores)

La precisión realizada por la Corte contrasta con los informes realizados por el Programa de las Naciones Unidas para el Desarrollo (2011), donde es posible encontrar que las comunidades negras se ven enfrentadas a problemas relacionados con la seguridad alimentaria y nutricional, la minería ilegal, los cultivos ilícitos y demás afectaciones por la violencia y el conflicto armado. De lo anterior se extrae el deber constitucional que tiene el Estado de salvaguardar a las comunidades étnicas, darles un trato diferenciado y garantizarles de forma prioritaria sus derechos fundamentales. Sobre el particular, en la sentencia T-485 de 2015 la Corte señaló: 
Las comunidades étnicas son titulares de derechos fundamentales específicos, que deben ser especialmente protegidos en razón de considerarse como sujetos de especial protección constitucional. Esta comprobación ha llevado a la Corte a definir un grupo de derechos de las comunidades diferenciadas, todos ellos relacionados con la prevención de su diversidad étnica y cultural, así como los demás derechos fundamentales que se adscriben a sus miembros. (p. 34)

Lo señalado encuentra fundamento en la Constitución Política de 1991, en cuyo articulado se ordena al Estado colombiano reconocer la protección de la diversidad étnica y cultural, definición que, sin duda alguna, incluye el reconocimiento de los valores y tradiciones de las etnias que lo conforman. Este mandato, incluido en el proceso constituyente de 1991, se acompasa con el Convenio 169 de 1989 de la Organización Internacional del Trabajo (oIт), ratificado por el Estado colombiano e incluido en el bloque de constitucionalidad con arreglo al artículo 93 superior.

Como se abordó supra, la oit, a través del Convenio 169, instó a los Estados para que tomaran las medidas encaminadas a garantizar y dar cumplimiento a los derechos de las comunidades indígenas y tribales. En razón a lo anterior, el Estado colombiano, mediante la Ley 21 de 1991, aprobó el convenio en mención y con ello la obligación de generar normas y políticas públicas protectoras de las comunidades étnicas, entre ellas las comunidades negras.

Uno de los elementos que evidencia la inclusión del Convenio 169 de la oit se encuentra en el artículo 70 de la Carta Política. Allí se afirma que es deber del Estado 
promover y fomentar el acceso a la cultura de todos los colombianos. Consonante con ello, reconoce la importancia de respetar todas las culturas que conviven en el país, para su supervivencia en el tiempo. En otras palabras, el Estado se obliga a proteger las culturas y etnias existentes, lo cual pasa por reconocer su autonomía, sus manifestaciones, saberes y conocimientos tradicionales.

Asimismo, el constituyente tuvo presente la importancia de reconocer a las comunidades negras derechos propios de su cultura y colectividad. A través del artículo 55 transitorio de la Constitución se fija el punto de partida para el reconocimiento de derechos asociados con su propiedad colectiva, prácticas tradicionales de producción y, sobre todo, creación de mecanismos específicos para la protección de la identidad cultural.

Entonces, a partir del marco constitucional y legal referido, en Colombia se da un paso importante para la protección y reconocimiento de las comunidades negras, pues en 1993 se promulgó la Ley 70, por la cual se desarrolla dicho artículo transitorio. En esta ley se consagran derechos encaminados a salvaguardar la diversidad étnica y cultural, la autonomía de las comunidades y los derechos que le deben ser reconocidos de forma especial sin alterar la esencia que les caracteriza.

En virtud del desarrollo normativo existente, de las garantías y el reconocimiento de la cultura de las comunidades negras y de la obligación de respetarles a estas los derechos fundamentales, debe realizarse un análisis sobre el viche del Pacífico como un producto medular e integrante de la cultura. Este destilado "deriva de la transformación artesanal de la caña de azúcar que realizan las poblaciones rurales ribereñas 
y costeras de la región" (Meza, Gorkys Murillo y Palacios, 2019, p. 11). En ese sentido, representa un aspecto fundamental en el desarrollo histórico de las comunidades negras, un bastión y baluarte de su cultura y prácticas ancestrales.

Para entender la importancia cultural y económica del viche es necesario referirse a sus antecedentes. Tiene sus inicios en las estancias de trapiche en Popayán y el valle del río Cauca, donde se dio en gran medida una explotación minera y, con ello, un desplazamiento de mano de obra esclava. Esto generó, según investigaciones históricas, una producción variada para el abastecimiento de azúcar, mieles y aguardiente a la población esclava en las minas, lo que causó un crecimiento de los trapiches donde se producían diferentes tipos de aguardientes, alrededor de lo cual se desarrollaron múltiples mercados (Meza et al., 2019).

Las nuevas comunidades de esclavos libres estaban constituidas por agrupaciones de familias negras con autonomía e independencia del esclavismo. Las actividades del diario vivir involucraron los cultivos de caña, el plátano y el cacao, lo que supuso que "del guarapo de la caña se [sacará] el 'viche', nombre con el cual se distingue al aguardiente de producción casera en el litoral Pacífico, que se diferencia del 'jecho' o aguardiente oficial" (Meza et al., 2019, p. 44). Posterior a ello, entre 1821 y 1851 , se dio un éxodo de las comunidades negras, las cuales crearon asentamientos basados en la producción de productos como la caña de azúcar. De eso se derivaron los cultivos agroindustriales, herramienta fundamental en la producción del destilado del viche del Pacífico.

Huelga acotar que existen diversas preparaciones a base de viche, la mayoría recetas que han surgido recientemente con la apertura de eventos folclóricos que se convierten en 
lugares de mercado. Sin embargo, existen preparaciones más antiguas como aquellas de la botella curada, el vinete o la tomaseca. Todos los productos, pese a su diferencia, provienen y tienen como base la caña de azúcar (Meza et al., 2019).

Por otro lado, debe resaltarse que con el viche se han desarrollado diferentes productos de carácter medicinal; el chuco o la tomaseca son preparaciones que se derivan del genérico bebedizo, aconsejado por las abuelas a las jóvenes que sufren los cólicos menstruales, y que también se utiliza para proteger la matriz de las enfermedades derivadas del parto (Meza et al., 2019). Este uso se circunscribe dentro del sistema médico tradicional y mágico-religioso afropacífico, el cual tiene una esencia terapéutica tradicional embera. No menos relevante es el hecho de que la técnica de estas preparaciones caseras las han transmitido las madres a sus hijas de generación en generación (Meza et al., 2019).

De ello se desprende que la producción y comercialización del viche se ajusta dentro de un contexto familiar y de relaciones de parentesco. La cultura generada alrededor del destilado construye un estructura compuesta por un parentesco que:

[...] conduce a explorar un entramado de relaciones entre las generaciones, de donde se destacan formas particulares de transmisión de deberes y derechos dentro de la unidad doméstica, así como alianzas entre unidades domésticas que conforman una red para el intercambio de la fuerza de trabajo, utensilios y el destilado mismo, basadas en una lógica de reciprocidad que fortalece los vínculos sociales. (Meza et al., 2019, p. 75) 
Como resultado de lo esbozado, se puede afirmar que el viche, además de tener un carácter cultural, ancestral y familiar, representa un activo económico para la comunidad negra. Su producción y comercialización se circunscribe a una actividad necesaria para una comunidad empobrecida y con carencia de trabajo (Meza et al., 2019). A razón de lo mencionado, la economía familiar encuentra que el $50 \%$ de sus ingresos proviene de estas actividades (Meza et al., 2019).

\section{Acciones adelantadas por el Grupo de Acciones Públicas en el caso "viche del Pacífico"}

Como se anunció al principio, uno de los más recientes casos de impacto nacional en los que la clínica jurídica ha participado es el del "viche del Pacífico", en cuya gestión se ha coadyuvado con los avances en el cumplimiento de los ods. En aras de un abordaje global de las acciones concretas adelantadas, fuerza exponer en síntesis los hechos que dieron lugar, no solo a la intervención del GAP de la Universidad del Rosario, sino a una serie de actuaciones tendientes a la protección de este destilado, en cuanto manifestación de la identidad cultural de las comunidades negras.

En los últimos años, el viche y demás manifestaciones propias de las comunidades negras han adquirido mayor visibilización en escenarios de encuentro cultural, como el Festival Petronio Álvarez. Allí es donde se acentúan los procesos de divulgación y familiarización de las tradiciones, las prácticas, los productos, entre otros, del Pacífico. En ese marco se celebra un concurso de los destilados de producción artesanal, como el viche del Pacífico. Uno de los aspirantes durante el último evento participó con una bebida de producción industrial que habría sido registrada, ante 
la Superintendencia de Industria y Comercio, como Viche del Pacífico.

Desde el entendido que la producción artesanal se erige como requisito de ineludible observancia para participar, el producto industrial quedó descalificado. Posteriormente, la Superintendencia de Industria y Comercio canceló de oficio la marca Viche del Pacífico, por vulgarización.

Con ocasión a la descalificación del participante, este interpuso una acción de tutela alegando la vulneración de sus derechos fundamentales a la igualdad, la salud pública, así como al debido proceso. E1 24 de julio de 2018, el Juzgado Quinto de Familia del Circuito de Oralidad de Cali resolvió negar por improcedente el amparo constitucional deprecado por el accionante. Por su parte, el 30 de agosto de 2018, el Tribunal Superior del Distrito Judicial de Cali, Sala de Familia, resolvió revocar la sentencia de tutela 169 del 24 de julio de 2018, proferida en primera instancia, y en su lugar negó el amparo tutelar al no advertirse vulneración de los derechos invocados por el actor.

Por último, enviada la tutela a la Corte Constitucional para su eventual revisión, la Sala de Selección 11, mediante Auto del 13 de noviembre de 2018, decidió no seleccionar la tutela, con lo que se dejó pasar una importante oportunidad para pronunciarse sobre los derechos fundamentales de las comunidades negras en relación con sus procesos culturales, pues la jurisprudencia actual sobre grupos étnicos está destinada, principalmente, a la protección de comunidades indígenas.

Desde entonces, se ha situado en la agenda de las comunidades negras y distintas organizaciones el referido asunto, esto es, la imposibilidad de apropiarse de saberes y 
conocimientos tradicionales - en cuanto al registro de marcas relacionadas con activos de producción común por parte de los sabedores y conocedores entraña el desconocimiento de su identidad cultural - Aunado al tema en comento, está una aparente omisión legislativa en materia de producción de bebidas alcohólicas de los grupos étnicos que preocupa a las comunidades negras. Al respecto, el parágrafo del artículo 7. ${ }^{\circ}$ de la Ley 1816 de 2016 — " por medio de la cual se fija el régimen propio del monopolio rentístico de licores destilados" - estableció que los cabildos indígenas - y asociaciones de cabildos- legalmente constituidos y reconocidos por el Ministerio del Interior, en virtud de su autonomía constitucional, continuarán produciendo sus bebidas alcohólicas tradicionales y ancestrales para su propio consumo, máxime cuando se empleen en ejercicio de su medicina tradicional. Como se desprende del aparte en cita, las comunidades negras no son destinatarias de dicha prerrogativa, pese a que el articulado superior les reconoce como sujetos de protección constitucional e impone un trato igualitario entre comunidades étnicas.

\section{Solicitud ante la Corte Constitucional}

\section{para selección de tutela}

El pasado diciembre de 2018, miembros del GAP, en conjunto con el Colectivo Destila Patrimonio, presentaron una solicitud ciudadana de insistencia en procura de un pronunciamiento orientado a 1) proteger la identidad cultural de las comunidades negras y 2) abordar lo relativo a los saberes y conocimientos tradicionales y la imposibilidad de apropiarse de ellos. La relevancia constitucional argüida en la solicitud de insistencia se resume en los siguientes apartes. 
En primer lugar, se indicó que el asunto del viche tiene un contenido económico y su eventual revisión respondía tanto a criterios subjetivos como objetivos - con sujeción a lo dispuesto en los artículos 51 y 52 del Acuerdo 02 de 2015-, los cuales son 1) la novedad del tema y 2) la urgencia de proteger un derecho fundamental. En lo que a la novedad del tema refiere, se consideró que si bien la identidad cultural ha sido analizada por la Corte Constitucional, no es menos cierto que el contenido de este derecho no se ha estudiado a la luz de las comunidades negras.

Por su parte, se sostuvo que el contenido económico estriba en que el viche ha logrado constituirse como una de las principales fuentes de recursos para quienes en su producción intervienen y la de sus núcleos familiares. En suma, el viche no solo se visibiliza como una fuente de ingreso o una actividad de la cual derivan su sustento, sino como un verdadero activo asociado a la expresión cultural, es decir, es una manifestación de sus saberes y conocimientos tradicionales, de su cultura e identidad, de donde deriva la correlación entre economía e identidad cultural.

Asimismo, se recordó que la apropiación abusiva de saberes colectivos, dinámicos y que se trasmiten de generación en generación atenta contra la subsistencia misma de la comunidad, tal y como se sostuvo en la sentencia T-477 de 2012. En ese sentido, la reivindicación de un derecho de propiedad sobre un activo cultural supone un grave riesgo para el universo de personas que derivan su sustento de su elaboración y comercialización, así como una amenaza a la identidad cultural de la comunidad. Esta última, referida al conjunto de elementos característicos del grupo social, constituye un derecho fundamental del colectivo y de cada 
una de las personas que lo conforman. Así, en la referida providencia la Corte Constitucional indicó que la identidad cultural, íntimamente ligada con los postulados constitucionales del Estado social de derecho de pluralismo, libertad y vida digna, se sustenta en la diversidad étnica que rige en este ordenamiento.

Con base en ello, se recordó que la identidad cultural constituye un derecho que se sustenta en el articulado superior y que encuentra respaldo en diversos instrumentos internacionales que a la materia refieren — como es el caso del Convenio 169 de la ort y las decisiones comunitarias, en cuyas disposiciones se acentúa la necesidad de proteger el conocimiento tradicional de las comunidades, en tanto a manifestación de su identidad-. Una de esas manifestaciones es la elaboración artesanal del viche, que fue amenazada por cuenta del registro de la marca Viche del Pacífico y la denuncia de la presunta afectación que la elaboración del destilado podía ocasionar.

\section{Intervención en el marco de la acción pública de inconstitucionalidad}

Lo preceptuado en el parágrafo del artículo 7. ${ }^{\circ}$ de la Ley 1816 de 2016 dio lugar a la acción pública de inconstitucionalidad presentada en febrero de esta anualidad por los ciudadanos Audrey Mena y Juan Sebastián Cárdenas. El aparte demandado, según los accionantes, evidencia una omisión legislativa relativa, por cuanto se excluyen como destinatarios de la prerrogativa, esto es, de la posibilidad de seguir produciendo las bebidas alcohólicas tradicionales a las comunidades negras, raizales y palenqueras. Ese trato diferenciado resulta atentatorio del derecho fundamental a 
la igualdad y la identidad cultural de las comunidades en mención.

En el marco de esta acción pública, el GAP presentó una intervención ciudadana solicitando que: 1) se declare la exequibilidad condicionada del parágrafo del artículo 7. ${ }^{\circ}$ (parcial) de la Ley 1816 de 2016, bajo el entendido de que la norma acusada no solo debe ser aplicable a los cabildos indígenas, sino también a los territorios de las comunidades negras, raizales y palenqueras, así como a sus espacios de interacción cultural y étnica, y 2) en caso de que la Corte se abstenga de declarar la exequibilidad condicionada de la norma acusada, solicitar subsidiariamente exhortar al Congreso de la República para que, en el término que la Corporación estime conveniente, regule el régimen apropiado y aplicable a las bebidas alcohólicas tradicionales de las comunidades negras, raizales y palenqueras, en aras de garantizar la protección de su identidad cultural y étnica. Este petitorio, valga la aclaración, se acompasa con las pretensiones de los accionantes.

El fundamento de la intervención se trifurcó en el análisis de 1) el marco regulatorio de los derechos de los grupos étnicos; 2) la violación del derecho a la igualdad de las comunidades negras, raizales y palenqueras, derivado de su falta de inclusión en el parágrafo del pluricitado artículo 7.', y 3) la igualdad y la garantía de otros derechos de las comunidades negras, raizales y palenqueras. En suma, dicho fundamento se puede sintetizar en los siguientes párrafos.

En primer lugar, se hizo referencia al marco jurídico con arreglo al cual se reconoce la protección a las comunidades negras. Al respecto, la Constitución Política de Colombia, los instrumentos internacionales que integran el bloque 
de constitucionalidad —entre ellos, el Convenio 169 de la OIT- y las demás disposiciones concordantes consagran la protección de las distintas comunidades étnicas y su identidad cultural, garantía esta que reafirma el carácter plural del Estado social de derecho. Salvo por las precisas prerrogativas que el constituyente previó para las comunidades indígenas, todo grupo étnico goza, en condiciones de igualdad, de la misma protección constitucional, no siendo dable al constituyente derivado el establecimiento de tratos diferenciados entre unos y otros.

Sobre el particular, se evidencia que la norma acusada por los actores, lejos de desarrollar algún mandato constitucional, estableció un trato diferenciado en virtud del cual se tiene como destinatario único de la facultad allí prevista a los pueblos indígenas. Se trata entonces de una disposición que contiene una excepción a favor de las comunidades indígenas para la producción y consumo de bebidas alcohólicas tradicionales y ancestrales, pero no para las demás comunidades étnicas que también han producido bebidas alcohólicas como una manifestación de su identidad cultural.

En ese sentido, se arguyó que el problema no era que las bebidas alcohólicas y ancestrales de los pueblos indígenas fueran incluidas como una excepción al monopolio rentístico del Estado, sino que si el legislador pretendía proteger las manifestaciones culturales que realizan grupos étnicos específicos mediante este tipo de productos, debió entonces amparar a todos aquellos grupos étnicos en cuya cosmogonía las bebidas alcohólicas desempeñan un papel central.

Para demostrar que tal disposición impone un trato diferenciado, se indicó que durante generaciones las comunidades negras han producido y consumido bebidas alcohólicas 
caracterizadas por su elaboración artesanal, por ser una expresión de su identidad cultural y por ser la continuidad de una tradición que se posibilita a través de la transmisión de saberes y su asidua reproducción. Es el caso del viche, que a lo largo de dos centurias ha representado un activo cultural y económico por excelencia de las comunidades del litoral pacífico.

Asimismo, se aseguró que su consumo no se reduce al uso recreativo, sino que se entrelaza con consideraciones culturales, con expresiones inherentes a la vida en comunidad y con la reivindicación implacable de su identidad. E1 conocimiento tradicional que atraviesa todo el proceso de elaboración del destilado revela el inescindible vínculo con el territorio, las creencias y prácticas culturales, con los antepasados, su presente y el devenir de su vida en comunidad. A su vez, se agregó que no debía pasarse por alto que las bebidas alcohólicas de las comunidades negras son también utilizadas para fines medicinales — v. gr. curación, mordedura de culebra, partos, entre otros-. Esa multiplicidad de usos se circunscribe a su sistema médico tradicional, a su organización y a la vivencia de la espiritualidad y del ser de los miembros del grupo. En suma, estas bebidas alcohólicas que se producen y consumen en el seno de las comunidades indígenas, negras, palenqueras y raizales constituyen un eje movilizador de la cultura, un elemento definitorio de aquella y un punto de distinción con aquellos licores que comúnmente se comercializan en las urbes.

Esta omisión, se concluyó por parte del GAP en la intervención, entraña la vulneración del derecho a la igualdad, pues no hay razón suficiente para argüir que el trato diferenciado establecido en el parágrafo acusado es necesario, 
y se funda a su vez en criterios de razonabilidad y proporcionalidad. Comoquiera entonces que el legislador olvida conferir la misma prerrogativa a las comunidades negras, raizales y palenqueras, aun cuando acreditadas las mismas condiciones que prevé el supuesto normativo del parágrafo del artículo 7. ${ }^{\circ}$ de la Ley 1816 de 2016, cuales son el carácter tradicional y ancestral de las bebidas, sumado a su uso medicinal tradicional, la omisión también hace nugatorio el derecho a la identidad cultural de estas comunidades y, de suyo, restringe las expresiones de una identidad que se desvanece ante la imposibilidad de seguir elaborando un activo de medular importancia, una expresión movilizadora de su cultura arraigada a sus prácticas, costumbres, su pasado, presente y el devenir en comunidad ${ }^{2}$ (Intervención de la Universidad del Rosario, 2019).

\section{Diseño de estrategias de visibilización}

De manera paralela a las dos acciones referidas, el GAP viene diseñando estrategias de visibilización en asocio con distintos colectivos y organizaciones con interés directo en el asunto del viche. Así, en diciembre de 2018 se celebró una mesa de discusión plural e interinstitucional, en la que se acercó a entidades públicas, colectivos, líderes y lideresas locales, y cuyo objeto fue evidenciar: 1) las preocupaciones que circundan respecto al asunto del viche del Pacífico con ocasión al registro de la marca, la tutela desatada y la presunta omisión identificada en la Ley 1816 de 2016; 2) las posibles estrategias para la protección de los saberes tradicionales y

2 A la fecha de redacción de este escrito, la acción todavía cursa en la Corte Constitucional, por lo que las resultas del proceso son aún inciertas. 
el activo cultural de las comunidades negras, y 3) los compromisos institucionales, como de las comunidades, para avanzar en la agenda del viche.

En la actualidad, se estudia la realización de foros académicos que permitan a la ciudadanía acercarse al debate del viche del Pacífico, conocer el patrimonio e identidad cultural de las comunidades negras, y nutrir la agenda con nuevas alternativas conducentes a la protección efectiva de los derechos de estas comunidades.

\section{Relación entre el caso de estudio y los Objetivos de Desarrollo Sostenible}

El caso del viche - entre el universo de casos de impacto local, nacional y regional en que el GAP participa - evidencia el rol fundamental de las clínicas jurídicas en el cumplimiento de los ods. No se trata de esfuerzos exclusivamente atribuibles al Estado, sino también a la contribución de grupos de interés público que, además de propiciar espacios para la formación práctico-académica (Torres Villarreal, 2013), brindan las herramientas necesarias para atender las necesidades legales de las comunidades menos favorecidas, al tiempo que coadyuva en la consecución de los oDs.

A través de las actuaciones hasta el momento desplegadas, se ha propendido hacia un verdadero cambio y transformación social, la generación de nuevas oportunidades y la superación de desigualdades que impiden el desarrollo de colectividades vulnerables. Este caso de interés público ya no solo denota el interés por hacer valer los principios en los cuales se sustenta el Estado social de derecho a través de estrategias de litigio tendientes a la defensa cabal de los derechos humanos (Torres Villarreal, 2013, pp. 728-729), sino 
también por avanzar en los objetivos mundiales mediante el diseño, la promoción y la adopción de medidas encaminadas a la superación de la pobreza, la protección del ambiente y la garantía de paz y prosperidad para todos.

Para respaldar tal aserto, hemos de referirnos a los objetivos en que se contribuye desde el preciso análisis del caso del viche del Pacífico. El primero de ellos es el fin de la pobreza. Como se ha dicho, el viche - y sus derivados- no solamente constituyen un activo cultural, sino también económico, del cual muchas familias del litoral pacífico derivan su sustento. Durante casi dos siglos, los vicheros se han valido de la producción del destilado como un medio de subsistencia de aquellos y sus núcleos familiares. Dicha actividad parece ser una respuesta a la endeble institucionalidad que caracteriza a los territorios donde se sitúan las comunidades negras, a los alarmantes índices de violencia, a las desigualdades y a una inocultable pobreza (Galvis, Moyano y Alba, 2016). En suma, la producción artesanal del viche ya no solo se erige como una manifestación de la identidad cultural, sino también como una fuente de ingresos que desafía un escenario de escasas oportunidades.

Así, las actuaciones desplegadas por el GAP se han encaminado a 1) obtener un pronunciamiento de fondo que se refiere a la imposibilidad de apropiarse de saberes y conocimientos tradicionales, como a activos de producción común en el seno de las comunidades negras; 2) permitir que a las comunidades negras se les reconozca la prerrogativa de producir sus bebidas alcohólicas tradicionales, máxime cuando estas son utilizadas también para su medicina tradicional, y 3) visibilizar esta manifestación de su identidad cultural. 
Los tres objetivos presentan una conexión inescindible con el fin de la pobreza. En el primer caso, asegura la producción artesanal del viche y, de suyo, la percepción de los ingresos que de su venta resultan, soslayando con ello la industrialización del destilado y la concentración de su comercialización en grandes inversiones. En el segundo caso, posibilita una excepción al monopolio rentístico del Estado, lo que permite la producción y consumo del destilado. Es decir, se actúa a fin de impedir que la producción del destilado, de escapar a la órbita de la excepción en comento, constituya una actividad contraria al ordenamiento vigente, caso en el cual se limitaría una ostensible fuente de ingreso de las familias que se dedican a su elaboración y comercialización —en el seno de la comunidad-. Por último, a través de las diversas estrategias de visibilización se pretende la asistencia del Estado en la formalización de los procesos que atraviesan la elaboración del viche, esfuerzos con los cuales se consolidaría una actividad que, de manera organizada y con la colaboración de las distintas instituciones, significaría un avance en la superación de la pobreza de estos productores y núcleos familiares. Piénsese, por ejemplo, en las innumerables oportunidades que provee el Festival Petronio Álvarez, espacio en el que se permite - y acentúa - la venta del viche.

El segundo de los objetivos con el cual se contribuye es la reducción de las desigualdades. Sobre el particular, el Programa de las Naciones Unidas para el Desarrollo ha indicado que para frenar las disparidades es necesario adoptar políticas sólidas que empoderen y promuevan la inclusión económica de todos, sin distingo de género, raza o etnia. Descendiendo al caso en concreto, la reducción de 
las desigualdades comienza con el reconocimiento de la producción de las bebidas tradicionales como una manifestación de su identidad cultural y, por contera, de la oportunidad de ser producida y comercializada en el seno de comunidades negras — que, como se ha sostenido, gozan de especial protección constitucional-.

Estas medidas implican la promoción de alternativas viables que suponen la percepción de ingresos para estas familias, con lo cual se trata de cercenar una profunda brecha económica entre estos núcleos y los de mayores ingresos.

Entre las metas de este objetivo también se encuentra la de garantizar la igualdad de oportunidades y reducir la desigualdad de resultados, incluso eliminando las leyes, las políticas o las prácticas discriminatorias y promoviendo legislaciones, políticas y medidas adecuadas a este respecto. Esta meta, de una importancia medular, se ajusta a las actuaciones que el GAP ha adelantado, pues es precisamente la eliminación de una normativa discriminatoria la que se pretende con el ánimo de otorgar igualdad de oportunidades a todas las comunidades étnicas, con especial atención a las comunidades negras, raizales y palenqueras. Sobre el particular, es precisamente ese el objeto de la acción pública de inconstitucionalidad en la que intervenimos: la ampliación de una prerrogativa - hasta ahora reconocida a comunidades indígenas - a las comunidades negras, raizales y palenqueras, pues la permanencia de aquella impondría un trato diferenciado que haría nugatorio el derecho a la igualdad y la identidad cultural de estos colectivos.

Aunque el análisis hasta ahora se ha reducido a los objetivos "fin de la pobreza" y "reducción de las desigualdades", nada obsta para que las actuaciones del GAP en el caso contribuyan 
con sendos avances en otras metas. Así, es dable sostener que la continuidad de la producción del viche posibilita también la realización de la producción y consumo responsable. Este objetivo (número 12, según corresponde) comprende entre sus metas 1) la gestión sostenible y el uso eficiente de los recursos naturales, 2) la reducción del desperdicio o la pérdida de alimentos en las cadenas de producción y suministro y 3) la gestión ecológica y racional de ciertos insumos. La elaboración del viche es la fiel concreción de aquellas, por cuanto promueve el empoderamiento sostenible de activos culturales de las comunidades negras a partir de sistemas productivos adaptativos que, aun cuando no reporten mayores rendimientos, son rentables para las necesidades inmediatas de las comunidades y la conservación de la biodiversidad (Meza et al., 2019, p. 16). Estas economías locales que participan en la producción del viche son atravesadas no solo por el acervo cultural que representan los conocimientos y saberes tradicionales, sino también por su comprensión del entorno y el aprovechamiento de los recursos. No en vano se le ha entendido como un "saber etnobotánico tradicional", un acumulado de conocimientos y prácticas que revela la relación entre las personas y su entorno natural (Meza et al., 2019).

De este modo, proteger el funcionamiento de la cadena productiva del destilado artesanal constituye una garantía para el uso racional de los recursos y la elaboración sostenible del activo cultural. Precisamente, la permanencia de las formas de producción y consumo domésticas y, por contera, la resistencia a la pretendida industrialización, se acompasa con el objetivo mundial de gestión sostenible y uso eficiente de recursos. En suma, es la elaboración artesanal la que se liga 
coherentemente con el uso de los recursos naturales (Meza et al., 2019, p. 26), con su aprovechamiento racional, con su vocación de permanencia en el tiempo, con la promoción de economías locales ambientalmente responsables y como proveedores de saberes que no mutan con la economía de mercado.

Cierto es que la participación del GAP en el caso del viche también incide, directa e indirectamente, en los objetivos de "hambre cero" y "salud y bienestar". En el primer caso, se ha determinado que entre las necesidades principales que cubren los productores a través de los ingresos provenientes del licor está la alimentación. Sobre el particular, en la obra La ruta del viche (Meza et al., 2019) se sostiene que en Sivirú, Villa Luz y Triana, el $100 \%$ de los ingresos se destina a alimentación; asimismo, en las principales localidades de comercialización - Pizarro, Buenaventura y Guapi- la mayor parte del ingreso (por encima del $80 \%$ en los tres casos) se dirige a alimentación. La relación en este caso se explica así: las actuaciones tendientes a continuar la elaboración del viche como consecuencia del reconocimiento de este como elemento intrínseco a la identidad cultural garantizan un sustento que es, por regla general, destinado a la compra de alimentos y a la eliminación del hambre en territorios que por distintos fenómenos son dables a padecer de aquella —en especial la infancia-.

Por su parte, en lo que a la salud y bienestar refiere, es inobjetable que entre el universo de usos de este activo están aquellos asociados a la medicina tradicional de las comunidades negras. Las prácticas y las creencias que sustentan el uso medicinal del viche se erigen no solo como respuesta a la ausencia del respaldo institucional que garantice el acceso, 
pronto, oportuno y adecuado al servicio de salud, sino también como una reivindicación de su forma de entender el mundo - la antítesis de la ortodoxia médico-científica-. Esta medicina tradicional, tanto como la de las comunidades indígenas, coadyuvan, entre otros, a reducir las tasas de mortalidad materna y neonatal, metas contenidas en el objetivo en comento.

\section{Conclusiones}

Hemos visto en los párrafos que anteceden que la educación legal clínica, para el caso del GAP, a partir de una apuesta que elude la desconexión entre la teoría y la realidad social y que propugna por la defensa del interés público, la protección de los derechos humanos y el ambiente, materializa los esfuerzos encaminados al logro de los ods. En ese sentido, la acción colectiva — que no solo se alimenta de los esfuerzos mancomunados de los distintos gobiernos- revela el involucramiento de una pluralidad de actores que fungen como agentes transformadores y de cambio.

El caso de estudio del viche del Pacífico en el que el GAP participa activamente permite respaldar tal aserto. A través de distintas actuaciones se ha procurado el reconocimiento de esta bebida de producción artesanal como una manifestación de su identidad, como un activo económico y cultural que no cede al monopolio rentístico del Estado y a la economía orientada al mercado, pues está fuertemente enlazada con los procesos de interacción en el seno de la comunidad. No se trata solo de un movimiento de personas y conocimientos que intervienen en la elaboración del viche, sino de una verdadera "herramienta" que contribuye a la superación de la pobreza, la reducción de las desigualdades, la producción sostenible 
y responsable del cuidado del ambiente, la eliminación del hambre y demás objetivos que integran la Agenda 2030.

Con ello, el Gap, por este y los demás casos de gran impacto en que contribuye, se habilita como un escenario que dinamiza y posibilita el cumplimiento de los oDs a través de la puesta en marcha de acciones y estrategias tendientes a la defensa del interés público.

\section{Referencias}

Almanza Iglesia, M. (2010). Las clínicas jurídicas y su pertinencia en la formación de abogados. Justicia, 15(18). Recuperado de http://revistas.unisimon.edu.co/index. php/justicia/article/view/923

Comisión Económica para América Latina y el Caribe (Cepal). (2016a). Agenda 2030 y los Objetivos de Desarrollo Sostenible: Una oportunidad para América Latina y el Caribe. Recuperado de http://www.sela.org/media/2262361/ agenda-2030-y-los-objetivos-de-desarrollo-sostenible.pdf

Comisión Económica para América Latina y el Caribe (Cepal). (2016b). Horizontes 2030: La igualdad en el centro del desarrollo sostenible. Ciudad de México: Autor. Recuperado de https://repositorio.cepal.org/bitstream/handle/11362/40159/4/S1600653_es.pdf

Galvis, L. A., Moyano, L. M., y Alba C. A. (2016). La persistencia de la pobreza en el Pacifico colombiano y sus factores asociados. Bogotá: Banco de la República, Centro de Estudios Económicos Regionales.

Girón, A. (2016). Objetivos del Desarrollo Sostenible y la Agenda 2030: Frente a las políticas públicas y los cambios de gobierno en América Latina [Editorial]. Problemas del Desarrollo, 47(186), 3-8. Recuperado de http:// 
www.scielo.org.mx/scielo.php?script=sci_arttext\&pid $=\mathrm{S} 0301-70362016000300003$

González Morales, F. (2004). El trabajo clínico en materia de derechos humanos e interés público en América Latina. Bilbao: Universidad de Deusto. Recuperado de http://www. deusto-publicaciones.es/deusto/pdfs/cuadernosdcho/ cuadernosdcho27.pdf

Intervención Universidad del Rosario. (2019, 8 de abril). Proceso 13.050 de la Corte Constitucional. Recuperado de http://www.corteconstitucional.gov.co/secretaria/archivo. php?id=8739

Ley 70 de 1993 (27 de agosto), por la cual se desarrolla el artículo transitorio 55 de la Constitución Política. Diario Oficial 41.013, de 31 de agosto de 1993.

Ley 1816 de 2016 (19 de diciembre), por la cual se fija el régimen propio del monopolio rentístico de licores destilados, se modifica el impuesto al consumo de licores, vinos, aperitivos y similares, y se dictan otras disposiciones. Recuperado de https:/www.funcionpublica.gov.co/eva/ gestornormativo/norma_pdf.php?i=88659

Londoño-Toro, B., Fager Sáenz, N. A, Torres-Villarreal, M. L., González Acosta, A. L., Luna de Aliaga, B. E. et al. (2009). Educación legal clinica y defensa de los derechos bumanos: Casos paradigmáticos del Grupo de Acciones Públicas (GAP). Recuperado de http://repository.urosario.edu.co/ handle/10336/12568

Meza, C. A., Gorkys Murillo, J. y Palacios, C. (2019). La ruta del viche: Producción, circulación, venta y consumo del destilado en el litoral Pacifico colombiano. s. 1.: Instituto Colombiano de Antropología e Historia-Universidad 
del Pacífico. Recuperado de http://www.unipacifico.edu. co:8095/unipaportal/documentos/rutadelviche.pdf

Organización Internacional del Trabajo. (1989). Declaración de las Naciones Unidas sobre los derechos indigenas. Washington: Autor.

Programa de las Naciones Unidas para el Desarrollo. (2011). Afrocolombianos: Sus territorios y condiciones de vida. Bogotá: Autor. Recuperado de http://www.co.undp.org/ content/dam/colombia/docs/DesarrolloHumano/undpco-cuadernoafro-2012.pdf

República de Colombia. Constitución Política de Colombia (1991).

Sentencia T-414 de 2015 (2 de julio). [mp Luis Guillermo Guerrero Pérez]. Recuperado de http://www.corteconstitucional.gov.co/relatoria/2015/t-414-15.htm

Sentencia T-485 de 2015 (5 de agosto). [MP Myriam Ávila Roldán]. Recuperado de http://www.corteconstitucional. gov.co/relatoria/2015/T-485-15.htm

Torres Villarreal, M. L. (2013). La enseñanza clínica del derecho: una forma de educación para el cambio social: La experiencia del gap de la Universidad del Rosario. Revista Facultad de Derecho y Ciencias Políticas, 43(119), 705-734. Recuperado de http://www.scielo.org.co/pdf/ rfdcp/v43n119/v43n119a07.pdf

Witker, J. (2007). La enseñanza clínica como un recurso de aprendizaje jurídico. Revista sobre Enseñanza del Derecho, 5(10), 181-207. 


\title{
La influencia de la telesalud en la ginecobstetricia y su relación con los Objetivos de Desarrollo Sostenible en salud
}

\author{
Daniel Castañeda Granados* \\ Erika Milena Moscoso"
}

Resumen: Las tecnologías de la información y la comunicación han influido en el campo de la ginecobstetricia en lo relacionado con las aplicaciones móviles médicas. Si bien es un escenario que plantea riesgo, también representa un reto fundamental para la salud y el desarrollo sostenible. Especialmente para lograr estándares de bienestar que permitan la plena salud sexual y reproductiva y el respeto a los datos personales sensibles, se requiere un sistema de controles más eficientes, de los cuales el Estado colombiano aún carece.

* Estudiante de décimo semestre. Miembro activo de la línea de investigación de Habeas Data en Salud. Correo electrónico: daniel.castanedag@urosario.edu.co

** Estudiante de décimo semestre. Miembro activo de la línea de investigación de Habeas Data en Salud. Correo electrónico: erika.moscoso@urosario.edu.co 
El presente capítulo busca evidenciar riesgos y propuestas de mitigación, bajo una revisión sistemática de las medical apps asociadas con asuntos sexuales y reproductivos.

Palabras clave: salud electrónica, salud móvil, medical apps, ginecobstetricia, control eficaz, $e$-health, derechos sexuales y reproductivos, tecnovigilancia.

\section{Introducción}

Durante la última década, las tecnologías de la información y la comunicación (TIC) han influido en el campo de la salud y la atención sanitaria. Sobre todo en el ámbito de la ginecobstetricia, se ha evidenciado un incremento progresivo de aplicaciones móviles destinadas a prestar servicios relacionados con la sexualidad y la maternidad, varias de ellas de uso frecuente para la toma de decisiones sexuales y reproductivas.

Este fenómeno de digitalización de la salud ha permitido que surjan conceptos como salud electrónica, telesalud, telemedicina, e-health, cibersalud, salud móvil, mHealth y teleeducación, que buscan explicar cómo la relación médicopaciente — tradicionalmente desplegada en espacios físicos hospitalarios - se ha desmaterializado para desenvolverse en escenarios digitalizados.

En el campo de la ginecobstetricia, el surgimiento de aplicaciones móviles o medical apps ha permitido que millones de mujeres en el mundo tengan acceso a servicios informáticos de calendario menstrual, asistencia ginecológica y registros prenatales y posnatales, únicamente mediante su descarga gratuita. Sin embargo, teniendo en cuenta que 
se trata de un mercado en desarrollo, no se ha estudiado ni sistematizado a cabalidad, y desde ya evidencia una amplia aceptación por parte de las usuarias para la autogestión de aspectos relacionados con salud sexual y reproductiva. La tendencia mundial es que exista una aprobación social de estos servicios, a pesar de los riesgos que implica este fenómeno tecnológico, lo que nos obliga a retomar la idea del riesgo como criterio de estudio de los nuevos entornos sanitarios.

Lo anterior, porque, en primer lugar, se trata de aplicaciones móviles que las autoridades sanitarias no están vigilando, pues no cuentan con una certificación sanitaria ni con una fase previa de ensayo clínico. En segundo lugar, porque se trata de aplicaciones móviles que recolectan datos personales sensibles y, por ende, requieren unas especificidades técnicas puntuales en materia de políticas de privacidad, consentimiento informado y control sobre la información médica suministrada. Por último, porque hasta el momento no existe en Colombia un estudio destinado a sistematizar y revisar el estado del arte en materia de telesalud aplicada al ámbito ginecológico y obstétrico, escenarios que se relacionan con los derechos sexuales y reproductivos de la mujer.

El presente capítulo tiene como finalidad presentar un primer estado de revisión sistemática de la telesalud en el campo de la ginecobstetricia. Para ello se tuvo como pregunta de investigación: ¿son suficientes los controles jurídicos existentes en Colombia para mitigar los riesgos que representan las aplicaciones médicas relacionadas con asuntos sexuales y reproductivos o debe consolidarse una regulación controlada por parte de las autoridades sanitarias y de salud? Es necesario resolver esta cuestión, pues la "promoción de la salud y bienestar" es uno de los objetivos del milenio, y 
la garantía de los derechos sexuales y reproductivos debe conciliarse con la innovación tecnológica, la cual no puede ser ajena a la vigilancia del Estado.

Para resolver la pregunta se aplicó una metodología cualitativa, descriptivo-metanalítica, ${ }^{1}$ que se encuentra en una fase de revisión sistemática, en la cual se emplearon técnicas de búsqueda selectiva en bases de datos para delimitar el concepto de salud electrónica y salud móvil. Posteriormente, se explica el fenómeno de las medical apps en el contexto de la ginecobstetricia desde el punto de vista del derecho comparado, para finalmente analizar y sistematizar cuáles son las medical apps que ofrecen servicios relacionados con la sexualidad y la maternidad en los principales mercados virtuales. Esta revisión tuvo como finalidad identificar las funcionalidades y objetivos de estas aplicaciones, así como alertar sobre los riesgos jurídicos y operacionales que existen para los derechos sexuales y reproductivos de la mujer. Para ello, se utilizó una metodología sui generis, denominada modelo de análisis de aplicaciones multimedia, propuesta por Gutiérrez (2003), y a pesar de que dicho modelo se creó para el análisis en el ámbito de aplicaciones móviles en España, sus dimensiones e indicadores son adaptables a nuestro tema de investigación. Las dimensiones propuestas en este modelo son: a) técnica, b) estética, c) interactiva, d) didáctica e) ideológica.

1 El metaanálisis hace referencia a un conjunto de herramientas cuantitativas o estadísticas que permite sistematizar datos de una colección de estudios. Permite analizar el tamaño del efecto de una variable con miras a determinar el grado, la razón y el contenido de un riesgo. 
La fortaleza de este modelo analítico, en contraste con otros, radica en que no se limita a verificar los aspectos técnicos o puramente tecnológicos de las aplicaciones, sino que abre un análisis a dimensiones sociales y culturales, lo que permite estudiar las aplicaciones no solo como innovaciones tecnológicas, sino como herramientas de incidencia social. Una vez identificados los riesgos mencionados, se analizó si el Estado colombiano cuenta con medios de control adecuados que permitan asegurar la vigencia del derecho a la salud y el habeas data de las usuarias digitales (e-pacientes). Para ello se diseñó una matriz que evaluara si los actuales sistemas de control en Colombia son suficientes para garantizar una protección efectiva en tres aspectos: seguridad, eficiencia y confidencialidad.

Se demostró que Colombia cuenta con controles genéricos medianamente eficientes, pero debe reforzar el sistema de protección bajo el fortalecimiento de la normatividad en habeas data y en asuntos de tecnovigilancia o control sanitario. Se trata de una proyección que se relaciona con la Agenda de las Naciones Unidas sobre Salud Sostenible para las Américas 2018-2030, cuyo séptimo objetivo es el de desarrollar capacidades para la generación, la transferencia, el uso de conocimiento y la tecnología en materia de salud, promoviendo la investigación e innovación, lo que obliga a los Estados a incluir la temática del $e$-health como parte de las agendas políticas.

\section{Salud electrónica, $e$-health, telesalud o cibersalud}

La telesalud, cibersalud, $e$-health o también conocida como salud electrónica ha sido definida por la Organización Panamericana de la Salud y Organización Mundial de la Salud 
(ops y oms, 20 I I) como el apoyo que las Tic ofrecen a la salud y a los ámbitos relacionados con ella, con inclusión de los servicios de atención de salud, la vigilancia y la documentación sanitaria, así como la educación, los conocimientos y las investigaciones en materia de salud. En concreto, se trata de un conjunto de actividades relacionadas con la salud, servicios y métodos, los cuales se llevan a cabo a distancia con ayuda de las Tic (Trevignani, 2014). En otras palabras, supone la interacción entre el médico y el paciente a través del uso de herramientas electrónicas para propósitos relacionados con la promoción, la prevención, el cuidado, el monitoreo y la supervisión de enfermedades y asuntos en salud (Jiménez Barbosa y Acuña Gómez, 2015).

Según Eysensback (2001), la e-salud es un campo emergente en la intersección de la informática médica, la salud pública y las iniciativas privadas, fundada en internet y las nuevas tecnologías, y su pretensión es mejorar la atención de la salud en los ámbitos local, regional y mundial, mediante el uso de las Tic.

En general, se trata de una apuesta mundial por empoderar al ciudadano para beneficiarse de los servicios de salud a través de medios tecnológicos y por permitir el acceso a poblaciones vulnerables a los beneficios del sistema de salud. Por ende, la salud electrónica es un fenómeno social que se aprovecha de las Tic para satisfacer necesidades de salud pública y que, a partir de una visión enfocada en el paciente, busca empoderarlo para potenciar la autogestión en salud.

Dentro del concepto de telesalud, debemos incluir los sistemas de autocontrol del paciente, de autogestión sanitaria, los dispositivos de telemonitorización, la telemedicina, la telecirugía, la teleconsulta, el intercambio electrónico (de 
mensajes, registros y bases de datos electrónicas), las redes regionales y nacionales, la historia clínica electrónica, las medical apps y todos los demás servicios que impliquen una asistencia a distancia en temas de salud y aspectos relacionados (Reig, 2002). En tal sentido, la "telesalud involucra sistemas que permiten registrar y tratar la información como la prestación de servicios proveídos a distancia en diferentes áreas, y que dan pie a nuevas especialidades tales como la telerradiología, telecardiología, teledermatología, teleoftalmología, telepatología, telepsiquiatría, entre otras"(Carnicero y Fernández, 2012, p. 45).

Por ejemplo, uno de los instrumentos clave es la historia clínica electrónica, la cual permite registrar toda la información relacionada con el paciente y ayuda al profesional de la salud a mejorar su diagnóstico, tratamiento y prescripción, logrando "modernizar las vías de comunicación entre los miembros del equipo de salud y pacientes para mejorar los tiempos de diagnóstico y tratamiento" (Carnicero y Fernández, 2012, p. 45). Se trata de aquella historia clínica "que reside en un sistema electrónico específicamente diseñado para recolectar, almacenar, manipular y dar soporte a los usuarios en cuento a proveer accesibilidad a datos seguros y completos" (Gonzales, 2011, p. 78).

Más allá de la historia clínica, se encuentran servicios más avanzados. Por ejemplo, según Correa Díaz (2017):

Los médicos que practican la telemedicina de manera general o a manera de especialistas proveen servicios online de información, interconsulta, visualización de imágenes, teleasistencia y telemonitorización en especialidades médicas de radiología, pediatría, urología, medicina interna, 
medicina física y rehabilitación, dermatología, gastroenterología, cirugía general y cardiología, a través de audio, videoconferencia y chat. (p. 374)

Por otro lado, en cuanto a las clasificaciones teóricas, es importante advertir que de la salud electrónica se derivan dos conceptos fundamentales: el primero, telemedicina, entendido como la provisión de servicios de salud a distancia en los componentes de promoción, prevención, diagnóstico y tratamiento y rehabilitación, por parte de profesionales de la salud. El segundo, salud móvil/m-salud m-health, que se refiere a la salud electrónica aplicada a los sistemas de telefonía móvil y redes de internet, esto es, la salud electrónica apoyada en la utilización de dispositivos móviles a partir del uso de aplicaciones móviles o medical apps, con vigilancia de un profesional de la salud o sin esta.

En síntesis, la salud electrónica implica toda una apuesta mundial por acercar la salud a los menos favorecidos. En primer lugar, busca empoderar al paciente, fortaleciendo su autonomía y asegurando altos estándares de salud. Pero, ante todo, es un reto para los ordenamientos jurídicos de los Estados que se encuentran vinculados a los objetivos de desarrollo sostenible en materia de salud, y más específicamente en la promoción del bienestar en su máxima expresión.

Así mismo, este movimiento informático — que permite concentrar información médica en aplicaciones móviles- se relaciona con las metas de la oms para el año 2030. Dicha organización se ha comprometido a "garantizar el acceso universal a los servicios de salud sexual y reproductiva, incluidos los de planificación de la familia, información y educación, y la integración de la salud reproductiva en las 
estrategias y los programas nacionales" (ops y oms, 2011). Especialmente, este objetivo se está desarrollando bajo el fenómeno de la salud móvil.

\section{La salud móvil y el fenómeno de las medical apps}

A efectos de esta investigación, el concepto más importante es el de salud móvil, por su estrecha cercanía con el fenómeno del internet y las aplicaciones móviles. La salud móvil puede definirse como el uso y aprovechamiento de tabletas y teléfonos inteligentes para cuestiones relacionadas con la salud. Tal y como lo recalca el Libro verde sobre sanidad móvil de la Comisión Europea (2014):

[...] la salud móvil tiene un gran potencial, ya que proporcionará a los ciudadanos los medios necesarios para gestionar su propia salud, mantenerse sanos más tiempo, mejorará la calidad de la asistencia sanitaria y el confort de los pacientes y a los profesionales de salud en sus trabajos. Todo esto, gracias al aumento de las aplicaciones móviles en salud.

En el campo doctrinal, Alonso-Arévalo y Mirón Canelo (2017), fundados en el informe de The Mobile Health Global Market Report 2013-2017: The Comercialization of mHealth apps, evidenciaron que el $70 \%$ de las medical apps existentes están destinadas a pacientes, y el $30 \%$ restantes son aplicaciones de uso profesional. Hacia 2017, la institución recopiló un total de 259.000 aplicaciones sobre salud disponibles en las principales tiendas de aplicaciones. En cifras más recientes, el instituto especializado eHealth22 indicó que más de 318.000 aplicaciones de salud están disponibles en las principales tiendas de apps, y si bien la mayoría están 
destinadas al paciente, muchas son creadas para los profesionales de medicina (Vega, 2018).

Este influjo progresivo de aplicaciones móviles descansa en la idea de salud 2.0, entendida como una forma integral de asistencia médica y sanitaria centrada en el ciudadano, en la que los actores involucrados (pacientes, profesionales, administradores y proveedores) participan de manera activa empleando las redes sociales y las herramientas de la web 2.0 para mejorar la calidad de vida de las comunidades (Carnicero y Fernández, 2012). En tal dirección, la salud móvil involucra toda comunicación o consulta entre profesionales de la salud y sus pacientes, utilizando las funciones de voz, texto, datos, imágenes o videos a través de un dispositivo móvil. Puede aplicarse, por ejemplo, al manejo de enfermedades crónicas y para los sistemas de salud representa una oportunidad para conectar pacientes, médicos y servicios de salud en áreas urbanas y rurales para mejorar la calidad de la atención (ops y oms, 2011, p. 34).

Por otro lado, gracias al desarrollo tecnológico del sector móvil y la incorporación de sensores y de otro tipo de dispositivos, cada vez es más fácil registrar parámetros físicos que indican el nivel de actividad y estado de salud de cada usuario de forma totalmente personalizada. (Mugaraza, 2017, p. 5)

Está atención personalizada se basa en un proceso que la doctrina ha denominado telemonitorización, y tiene como presupuesto el almacenamiento inteligente de datos en soportes que cuentan con la capacidad de interpretar datos personales, registrarlos, dar una respuesta médica y generar 
un monitoreo constante de una situación de salud. Por ejemplo, la aplicación Migraine Buddy permite registrar la hora, la intensidad del dolor, los efectos secundarios y la medicación de una migraña, para determinar posibles factores que la desencadenaron. Además de lo anterior, en caso de ser mujer, permite asociar el dolor con aspectos relacionados con el ciclo menstrual. Por otro lado, encontramos Grey Matters, aplicación destinada a pacientes con Alzheimer y demencia senil, que cuenta con una opción de identificación de familia y amigos en la cual recuerda su relación con cada uno y algunas experiencias vividas.

Sin embargo, más allá de toda la innovación social que condensa el concepto de salud 2.0, representa riesgos para la seguridad y confidencialidad de los datos personales, y al desplegarse en un escenario de internet neutral y no regulado no garantiza plenamente la seguridad del paciente en cuestiones básicas de salud. En la tabla 1 se presentan las principales ventajas y desventajas que representa la salud electrónica en el ámbito de la salud móvil, la salud 2.0 y, en concreto, las medical apps.

Tabla 1. Ventajas y desventajas de la salud móvil en el ámbito sanitario

\begin{tabular}{|c|c|}
\hline Ventajas & Desventajas \\
\hline $\begin{array}{l}\text { Mejora la relación médico-paciente, } \\
\text { la comunicación y el tratamiento de } \\
\text { enfermedades. } \\
\text { - Permite crear sistemas de autogestión } \\
\text { en salud que facilitan al usuario } \\
\text { entender su propio cuerpo y sus } \\
\text { propias enfermedades. } \\
\text { - Son de fácil acceso. La mayoría de las } \\
\text { med-apps son gratuitas. }\end{array}$ & $\begin{array}{l}\text { - Las aplicaciones móviles en salud no cuentan } \\
\text { con vigilancia y control de organismos } \\
\text { especializados. Se ofertan a través de } \\
\text { tiendas de aplicaciones sin ningún tipo de } \\
\text { intervención del Estado. } \\
\text { - Recolectan datos personales sensibles y existe } \\
\text { un alto riesgo de tratamiento indebido e ilícito. } \\
\text { - Varias med-apps funcionan bajo sistemas } \\
\text { de inteligencia artificial, pero no surten un } \\
\text { proceso previo de ensayo clínico que permita } \\
\text { garantizar su eficiencia y seguridad sanitaria. }\end{array}$ \\
\hline
\end{tabular}




\begin{tabular}{|l|l|}
\hline \multicolumn{1}{|c|}{ Ventajas } & \multicolumn{1}{c|}{ Desventajas } \\
\hline $\begin{array}{l}\text { Disminuyen la demanda de atención, } \\
\text { y le permiten al sistema de salud } \\
\text { ahorrarse costos de gestión médica } \\
\text { directa. }\end{array}$ & $\begin{array}{l}\text { Existe una amplia desinformación de los } \\
\text { usuarios en cuanto a los fines para los cuales } \\
\text { se recogen sus datos personales, incluso } \\
\text { Enriquecen la relación médico- } \\
\text { paciente y fortalecen el rol activo } \\
\text { del paciente para cuestionar el saber } \\
\text { científico. }\end{array}$ \\
& $\begin{array}{l}\text { Existe una brecha social entre quienes tienen } \\
\text { acceso a internet y quienes no cuentan, o no } \\
\text { saben utilizar los medios informáticos, lo }\end{array}$ \\
& $\begin{array}{l}\text { que se convierte en una brecha digital donde } \\
\text { no todos pueden beneficiarse de los servicios } \\
\text { de la salud móvil. }\end{array}$ \\
\hline
\end{tabular}

Fuente: elaboración propia a partir de Alonso-Arévalo y Mirón-Canelo (2017).

Tanto las ventajas como las desventajas se han enfrentado en el campo científico. En 2012, la Unión Internacional de Telecomunicaciones y la oms lanzaron la iniciativa Salud Móvil para luchar contra las enfermedades crónicas no transmisibles, desde una perspectiva de teleeducación o e-learning, al ver la telesalud como una ventaja para consolidar proyectos de salud pública. No obstante, a pesar del desarrollo social, autores como Alonso-Arévalo y MirónCanelo (2012) y Santamaría-Puerto y Hernández-Rincón (2015) indican que estas aplicaciones ponen en riesgo la salud pública, pues entrañan potenciales riesgos al actuar sin la vigilancia y el control de una autoridad sanitaria. Este problema se encuentra estrechamente relacionado con la generación y el contenido de las aplicaciones móviles, pues estas son de creación libre y muchas veces su generación está motivada por razones comerciales y no por cuestiones médicas (Santamaría-Puerto y Hernández-Rincón, 2015).

Se ha destacado, por ejemplo, que de las 94 aplicaciones temáticas de microbiología, solo el 34\% había incluido la participación de profesionales médicos en el diseño y generación de la aplicación. Considera que la falta de rigor médico de las 
med-apps, especialmente aquellas destinadas al cuidado personal y autogestión en salud, ponen a los pacientes en una situación de vulnerabilidad, por falta de conocimiento y formación en medicina o por la excesiva confianza que se le tiene a dichas aplicaciones móviles con relación a su rigor científico.

Importante recalcar, que la Food and Drug Administration (FDA) introdujo en Estados Unidos normas y directrices tendientes a regular las aplicaciones móviles. Actualmente, la FDA entiende por aplicaciones móviles todas aquellas plataformas que se utilizan como "accesorios para un dispositivo médico regulado", es decir, aplicaciones que se conectan a un dispositivo existente implantable o portátil, o que en sí mismas constituyan un dispositivo médico regulado (FDA, 2013).

La FDA solo le exige autorización a las aplicaciones médicas que representen un riesgo mayor para los pacientes; en otros términos, solo como dispositivos médicos, pero cuando se relacionan con un dispositivo médico regulado a modo de accesorio o complemento. En 2018, la entidad reconoció a Natural Cycles como la primera aplicación anticonceptiva digital y abrió el debate sobre la salud móvil en el ámbito ginecobstétrico.

Este último escenario se relaciona directamente con la salud sexual y reproductiva de la mujer y, por ende, requiere un estudio diferenciado, pues está asociado con temáticas como la planificación, la seguridad, la salud femenina y con el cumplimiento de los estándares internacionales de protección de la mujer. A efectos de lo anterior, se hace necesario analizar la salud móvil en el ámbito ginecobstétrico para determinar si deben o no existir controles mucho más rigurosos que permitan tutelar los derechos de la mujer en una zona de internet globalizado. 


\section{Salud móvil en el ámbito ginecobstétrico}

En el ámbito de la ginecobstetricia, ${ }^{2}$ la salud móvil se ha desplegado en un escenario complejo. La gestación y el parto constituyen etapas de vulnerabilidad para la mujer, y en el ámbito sexual, el ciclo menstrual constituye una de las etapas de mayor incidencia en la vida social femenina, por lo que hablar de la telesalud aplicada al escenario ginecobstétrico, inevitablemente, nos pone en el campo de la salud sexual y reproductiva de la mujer. De igual manera, el Pacto Internacional de Derechos Económicos Sociales y Culturales, la Convención Americana de Derechos Humanos, la Convención sobre la Eliminación de todas las Formas de Discriminación contra la Mujer, entre otros instrumentos, consagran la obligación del Estado de proteger la salud integral de la mujer en todas sus etapas de vida.

En concreto, la ginecobstetricia se encuentra muy relacionada con cuestiones epidemiológicas y de salud pública. La oms alertó que la prematuridad, la asfixia neonatal y las infecciones son las principales causas de defunción durante el primer mes de vida (oms, 2019). Entre las diez principales patologías generales que aparecen censadas en los países de la Latinoamérica están enfermedades como carcinoma de útero, preeclampsia, eclampsia, hipoxia fetal intrauterina y bajo peso de neonatos al nacer. Así mismo, han aumentado los casos de cáncer de cuello uterino, síndrome de ovario poliquístico, endometriosis y los denominados trastornos del ciclo menstrual.

2 La ginecobstetricia comprende dos aspectos: la ginecología, que se encarga de las enfermedades y la prevención de estas en el sistema reproductor femenino, y la obstetricia, que es la especialidad para el cuidado del embarazo, así como la atención del parto y los cuidados posnatales. 
Por otro lado, en lo que tiene que ver con la ginecología, "desde hace más de diez años existen equipos que permiten establecer diagnósticos primarios de carcinomas, tales como videocolposcopios portátiles de alta resolución que permiten visualizar en cuello uterino lesiones susceptibles de hisopado o biopsia" (Nader, 2018). Así mismo, en el campo de la obstetricia existen múltiples marcas de monitores fetales para embarazo único y embarazos gemelares, que pueden ser utilizados para control prenatal y en la etapa interparto (Nader, 2018).

Sin embargo, durante los últimos años, la ginecobstetricia se ha visto invadida por la salud móvil, especialmente por medical apps. En efecto, se ha establecido que en los mercados virtuales de aplicaciones más importantes del mundo, como Google Apps y AppStore, hay una cantidad importante de aplicaciones móviles destinadas a prestar servicios de autogestión en cuestiones de menstruación, ovulación, gestación y parto, a partir de sistemas de teleeducación y tratamiento de datos personales relacionados con la salud sexual y reproductiva de la mujer usuaria. En principio, estas med-apps ginecobstétricas funcionan a través del registro, almacenamiento y tratamiento de datos personales que, una vez relacionados por sistemas algorítmicos y de inteligencia artificial, pueden emitir una respuesta médica, sea informativa, expositiva, enunciativa, o preventiva.

En el ámbito ginecológico se destacan los calendarios menstruales. Estos permiten seguir el ritmo menstrual, identificando los periodos fértiles, los periodos de ovulación y las fechas de menstruación. Así mismo, permiten seguir el método anticonceptivo o de planificación $y$, consecuentemente, emitir recordatorios sobre píldoras, avisos de retraso 
o de inminencia del próximo periodo menstrual. Entre las más destacadas se encuentra Eve, Natural Cycles, Mi Calendario Menstrual, Flo, entre otras. Muchas registran cambios físicos, emocionales y en el deseo sexual.

Importante mención requiere la aplicación sueca $\mathrm{Na}-$ tural Cycles, que adquirió su aprobación médica por parte de la FDA bajo el ropaje de "método anticonceptivo", lo que ha despertado varios cuestionamientos entre usuarios y profesionales de la salud, por tratarse de un caso hito en el ámbito de la ginecología y que da pie para hablar de nuevos conceptos como el de planificación digital.

En el ámbito obstétrico, se destacan las calculadoras de embarazo, que permiten proyectar las semanas, la edad gestacional y el seguimiento al embarazo a partir de datos suministrados por la usuaria relacionados con aspectos físicos y psicológicos. De igual forma, funcionan como recordatorio para consultar citas y pruebas indispensables en cada periodo, así como medio de información educativa relativa a las características de cada semana del embarazo, incluso sobre aspectos relacionados con la alimentación y cuidados necesarios en cada uno de los meses de gravidez. Algunas de estas sirven como planeador para las visitas a especialistas y otras registran imágenes interactivas sobre cómo evoluciona el no nato desde el momento de la concepción hasta el parto. Mi Embarazo, por ejemplo, suministra consejos para sobrellevar las náuseas, cómo dormir al bebé, pasando incluso por temas de nutrición y crianza.

Empero, todas estas aplicaciones se encuentran por fuera de la vigilancia de las autoridades de salud de los Estados, y solo en el caso de la FDA se ha creado una conciencia de regulación a través del reglamento FDA Mobile Medical Applications: 
Guidance for Industry and Food and Drug Administration Staff. En este, la autoridad de vigilancia sanitaria reconoce que la adopción y el uso generalizado de las tecnologías móviles está abriendo nuevas formas de la prestación de servicios de salud; sin embargo, considera que debe existir supervisión de las aplicaciones que representan mayores riesgos a los pacientes. Este documento dio pie a todo un esquema de regulación en el derecho comparado, pues este nuevo influjo tecnológico debe analizarse no desde una perspectiva neutral, sino desde un enfoque basado en el riesgo.

\section{Regulación de las medical apps en el derecho comparado}

\section{Estados Unidos (enfoque basado en el riesgo)}

En 2013, la FDA de Estados Unidos emitió el reglamento FDA Mobile Medical Applications: Guidance of Industry and Food and Drug Administration Staff, donde define el concepto de mobile medical applications bajo la noción de dispositivo médico. En el capítulo III dispone que para efectos del reglamento:

[...] se entenderá por "Mobile medical app" toda aquella aplicación que se relacione con el concepto de "dispositivo" $\mathrm{y}$, además, cumpla con dos funcionalidades principales: (i) esté destinada a ser utilizada en la realización de una función de un dispositivo médico regulado. (ii) Que la aplicación móvil tenga funciones de dispositivo médico. En consecuencia, según el propio documento, si una aplicación móvil está destinada a ser utilizada en función de dispositivo médico; es decir, si se utiliza para el diagnóstico 
de una enfermedad, o la curación, mitigación, tratamiento o prevención de enfermedad, se considera un dispositivo médico, independientemente de la plataforma en la que se ejecuta. Desde este panorama, la FDA aplica su vigilancia sobre aquellas aplicaciones que están destinadas a complementar un dispositivo médico y que impliquen un alto riesgo para el paciente. (Prystowsky y Walland, 2018)

A partir de esta regulación, la FDA ha aprobado más de cien aplicaciones de salud, la mayoría de las cuales se centran en la gestión de patologías crónicas como la diabetes, el asma, el control de la tensión arterial, entre otras (Santillán García y Martínez Casas, 2015). En primer lugar, la regulación tiene un enfoque basado en el riesgo, esto es, se trata de un sistema de tecnovigilancia ultima ratio según el cual solo se tiene autoridad sobre las aplicaciones móviles que impliquen un riesgo a la seguridad del paciente. Por ejemplo, entre las aplicaciones de alto riesgo se encuentran aquellas que realizan electrocardiografía ${ }^{3}$ o electroencefalografía, las que miden los movimientos oculares para diagnosticar trastornos del equilibrio, aplicaciones que actúan como control remoto inalámbrico, controles para tomografía computada

3 La electrocardiografía es un método rápido, sencillo e indoloro en el cual se amplifican los impulsos eléctricos del corazón y se registran. Ello proporciona información sobre el lugar del corazón que desencadena cada latido (el nódulo sinusal, también llamado nódulo sinoauricular), las vías nerviosas que conducen los estímulos cardiacos y la frecuencia y el ritmo del corazón. A veces, puede mostrar una hipertrofia cardiaca (por lo general como consecuencia de la hipertensión arterial) o que el corazón no está recibiendo suficiente oxígeno a causa de una obstrucción en uno de los vasos sanguíneos que irrigan el corazón (las arterias coronarias) (Shea, 2017). 
y aplicaciones que controlan estimuladores neuromusculares implantables (Cortez, Cohen e Kasselheim, 2014, p. 376).

En cuanto a las aplicaciones que representan un mínimo riesgo para los pacientes, la FDA tiene la facultad discrecional de ejercer supervisión, sin imponer el requisito de registro para su funcionamiento. Dentro de la anterior categoría estarían aquellas que desarrollan las siguientes funciones (Alonso-Arévalo y Mirón-Canelo, 2017):

- Ayudar a los pacientes (es decir, a los usuarios) a autogestionar su enfermedad o condiciones sin proporcionar tratamiento específico o sugerencias de tratamiento.

- Proporcionar herramientas simples a los pacientes para organizar y rastrear su información de salud.

- Facilitar el acceso a la información relacionada con las condiciones de salud o los tratamientos de los pacientes.

- Ayudar a los pacientes a documentar, mostrar o comunicar condiciones médicas potenciales a los proveedores de atención médica.

- Automatizar las tareas simples para los proveedores de atención médica.

- Permitir que los pacientes o los proveedores interactúen con los sistemas de registro de salud personal o de registro electrónico de salud.

- Transferir, almacenar, convertir el formato y mostrar los datos recogidos por el dispositivo médico a otro dispositivo médico. 
Dentro de las aplicaciones con riesgo mínimo, podemos ilustrar aquellas destinadas a pacientes o mujeres embarazadas, aquellas que realizan un seguimiento de los medicamentos y brindan recordatorios configurados por el usuario y aquellas destinadas a individuos para registrar, rastrear, evaluar o tomar decisiones o sugerencias de comportamiento relacionadas con el desarrollo o mantenimiento de la condición física, la salud o el bienestar general. Por ejemplo, podemos mencionar Social Diabetes, que permite llevar un registro de consumo de alimentos para registrar las concentraciones de insulina y glucosa; ayuda también a controlar el riesgo de hipoglucemia a partir de una red de información que permite compartir ideas, consejos y experiencias.

Específicamente, en el ámbito de la ginecobstetricia, el calendario menstrual Natural Cycles es un hito en materia de tecnovigilancia sanitaria en asuntos relacionados con la ginecobstetricia. Se trata de una aplicación sustentada en estudios clínicos que permite evaluar la efectividad de los ciclos naturales para uso anticonceptivo. La aplicación tuvo una tasa de fracaso de "uso perfecto" del 1,8\%, lo que significa que 1,8 de cada 100 mujeres que la usan durante el año incurren en riesgo de quedar embarazadas (FDA, 2018). Natural Cycles utiliza su propio termómetro y algoritmo basal para calcular cuándo una mujer es fértil o infértil, y para ello requiere que las usuarias registren sus ciclos menstruales y tomen su temperatura basal ${ }^{4}$ a la misma hora cada

4 La temperatura corporal cambia ligeramente durante el ciclo menstrual. Para la mayoría de las mujeres, la temperatura típica antes de la ovulación es de 96 a $98^{\circ} \mathrm{F}\left(35,5\right.$ a $\left.36,6{ }^{\circ} \mathrm{C}\right)$. Después de ovular, sube a entre $97^{\circ} \mathrm{F}$ y $99^{\circ} \mathrm{F}\left(36,1^{\circ} \mathrm{C}\right.$ y $\left.37,2^{\circ} \mathrm{C}\right)$. 
mañana, antes de levantarse de la cama. Debido a que se trata de una aplicación que se complementa con un dispositivo médico (termómetro basal), la FDA exigió su pleno registro por considerarla de alto riesgo.

Es importante recalcar que para determinar el riesgo de una medical app, la FDA utiliza una clasificación de intensidad, a saber: class $I$, que involucra aquellas de riesgo bajo; class II, que involucra aquellas de riesgo moderado, y class III, que involucra aquellas de alto riesgo. En tal vía, para comercializar un nuevo dispositivo de clase III, la FDA precisa una aprobación previa a la comercialización, que generalmente implica la acreditación de estándares en seguridad clínica y buenas prácticas en cuanto a la protección de datos personales.

En cuanto a las de clase iI, permite a los fabricantes presentar una notificación mucho menos rigurosa, conocida como notificación previa a la comercialización, en la cual declara que su aplicación cumple de forma equivalente con los estándares del dispositivo médico físico. $\mathrm{Y}$ respecto a la clase I, están exentos de todo requisito, y únicamente se tendría un control discrecional por parte de la FDA (Cortez, Cohen e Kasselheim, 2014, p. 376).

Para aquellas aplicaciones consideradas dentro del ámbito de lo regulado, se hace necesario validar la funcionalidad, la fiabilidad y la exactitud de los datos generados. A juicio de Prystowsky y Walland (2018), dicha validación puede requerir pruebas piloto o comparaciones directas con datos tradicionales generados a partir de visitas clínicas, análisis de laboratorio y herramientas de validación médica (p. 57). La FDA comanda el sistema de tecnovigilancia digital fundado en un enfoque de riesgo, donde las aplicaciones se conciben 
como dispositivos médicos regulados, por lo que no pueden desplegarse económicamente sin autorización previa.

\section{España (enfoque basado en la seguridad informática)}

E1 Estado español incluyó la "Estrategia de calidad y seguridad en aplicaciones móviles de salud", en la cual puso en marcha un régimen de sellos de calidad con validez internacional. El estado de Andalucía, a través de su Agencia de Calidad Sanitaria, creó el sello AppSaludable, que garantiza la calidad en el uso, el contenido y la seguridad de la información (Santillán García y Martínez Casas, 2015). Se trata de un "reconocimiento público de calidad y seguridad, que acredita que la app cumple con los requisitos impuestos por el sello de calidad español con validez internacional" (Sánchez García, 2017). Entre las aplicaciones relacionadas con la ginecobstetricia, y que cuentan con el respectivo sello de calidad, encontramos Aula Cáncer de Mama y Contracepción, útil para ayudar a los profesionales de la salud a elegir el medio anticonceptivo con los criterios médicos de elegibilidad de la oms. Para el efecto, la autoridad sanitaria realiza una evaluación relacionada con el diseño/pertinencia, calidad/seguridad y confidencialidad/privacidad (tabla 2).

Según los criterios anotados, el esquema español les pone el relieve a las políticas de privacidad, confidencialidad y seguridad de los datos personales, dándole una nueva perspectiva al enfoque de riesgo, no limitado únicamente al cuidado en salud, sino a la protección del habeas data. Se trata de un modelo mucho más amplio, que se funda en la noción de seguridad y calidad. 
Tabla 2. Criterios para conceder el sello distintivo

\begin{tabular}{|l|l|}
\hline \multirow{1}{*}{ Diseño-pertinencia } & $\begin{array}{l}\text { Pertinencia: la app define de forma clara su alcance y } \\
\text { finalidad. } \\
\text { - Accesibilidad: la app sigue los principios de diseño universal. } \\
\text { Diseño: la app atiende a las recomendaciones, patrones y } \\
\text { directrices de diseño recogidas en las guías oficiales. } \\
\text { Testeo: la app de salud ha sido testada con usuarios } \\
\text { potenciales de forma previa a su puesta a disposición del } \\
\text { público. }\end{array}$ \\
\hline Calidad-seguridad & $\begin{array}{l}\text { Adecuación: la app se adapta al tipo de destinatarios al que se } \\
\text { dirige. }\end{array}$ \\
\hline Transparencia: ofrece información transparente sobre la \\
identidad y localización de sus propietarios. \\
Autoría: identifica a los autores y responsables de sus \\
contenidos, así como su cualificación profesional. \\
Actualización: advierte actualizaciones que inciden o \\
modifican funcionamientos o contenidos en salud.
\end{tabular}

\section{Unidades de investigación y metodología}

A continuación, se explica el fenómeno de las medical apps en el contexto de la ginecología y la obstetricia, para finalmente analizar y sistematizar cuáles son las que en los principales 
mercados virtuales ofrecen servicios relacionados con la sexualidad y la maternidad.

Debido a la variedad del mercado de aplicaciones móviles, únicamente se tomaron las relacionadas con las áreas de obstetricia y ginecología, específicamente calendarios menstruales y calculadoras de embarazo, ofertadas en Google Android y Apple-Ios. En cuanto a los criterios de selección de las aplicaciones, se tuvieron en cuenta los siguientes factores:

- Calificación digital: solo se tomaron en cuenta las apps con calificación superior a 4,6 o 4 estrellas y media. Por tanto, quedaron excluidas aplicaciones —al menos en esta fase investigativa - con calificación baja o media.

- Destinatarios: solo se tomaron en cuenta las más descargadas, por lo que quedaron excluidas aquellas apps, con poco nivel de descarga y baja demanda de usuarios.

- Globalización: se estudiaron aplicaciones destinadas al público en general. Por lo tanto, quedaron excluidas las destinadas a un país o comunidad en concreto.

- e-paciente: solo se tomaron aquellas aplicaciones destinadas al paciente y quedaron por fuera aquellas destinadas a los profesionales de la salud.

- Android/Ios: únicamente se analizaron las aplicaciones ofertadas en Google Apps y AppStore.

Si bien la investigación hasta ahora se encuentra en fase de revisión sistemática, se viene utilizando el modelo de análisis de aplicaciones multimedia, propuesto por Gutiérrez 
(2003) y utilizado por Trevignani (2014) en su investigación aplicada a telemedicina general en el contexto español, en la cual analizó aplicaciones relacionadas con aspectos de cardiología y medicina preventiva general.

Las dimensiones propuestas en este modelo son las siguientes: técnica, estética, interactiva, didáctica e ideológica. Cabe advertir que en esta investigación únicamente se analizó la fase técnica, porque esta dimensión analiza los aspectos relacionados con la calidad de programación y las prestaciones técnicas relacionadas con la funcionalidad de la aplicación. Por otro lado, la dimensión interactiva analiza la interfaz del usuario y la plataforma, en cuanto al flujo de datos personales (Trevignani, 2014).

Así, los resultados se ubican en dos secciones: una enfocada en el ámbito de la ginecología y otra en el ámbito de la obstetricia, donde se analizan las ocho aplicaciones de área más representativas. En la tabla 3 se presentan las dimensiones técnicas y la dimensión interactiva. Para lo ginecológico hay un análisis técnico y otro interactivo; mientras que en lo obstétrico se presenta un análisis técnico-interactivo, pues varias de las funciones tienen relación estrecha con el flujo de datos personales.

Finalmente, se plantea una relación de datos, con miras a determinar cuáles son las funciones que caracterizan a las med-apps y cuáles son los datos que se recolectan según el grado de sensibilidad. Lo anterior, con miras a realizar un análisis comparativo inicial que permita reforzar la idea de una tríada de protección que asegure la seguridad, la eficiencia y la privacidad de la $a p p$ frente al usuario receptor del servicio de salud móvil. 


\section{Resultados de la investigación}

\section{Ginecología}

Fase técnica

En esta fase se recopilaron las med-apps más representativas $\mathrm{y}$ se identificaron las funciones principales desde un punto de vista comparativo (tablas 3 y 4 ).

Tabla 3. Análisis de funciones: dimensión técnica

\begin{tabular}{|c|c|c|c|c|c|c|c|c|}
\hline & Clue & Eve & Flo & $\begin{array}{l}\text { Calendario } \\
\text { Menstrual }\end{array}$ & Iperiod Lite & Period Tracker & Pink Pad & $\begin{array}{c}\text { Mi Calendario Ciclo } \\
\text { Menstrual }\end{array}$ \\
\hline Información del ciclo actual & $\mathrm{X}$ & $\mathrm{X}$ & $\mathrm{X}$ & $\mathrm{X}$ & $\mathrm{X}$ & $\mathrm{X}$ & $\mathrm{X}$ & $\mathrm{X}$ \\
\hline $\begin{array}{l}\text { Información y seguimiento del } \\
\text { método anticonceptivo }\end{array}$ & $\mathrm{X}$ & & $\mathrm{X}$ & $\mathrm{X}$ & $\mathrm{X}$ & $\mathrm{X}$ & & $\mathrm{X}$ \\
\hline Tomas de temperatura basal & $\mathrm{X}$ & & & & & & $\mathrm{X}$ & $\mathrm{X}$ \\
\hline $\begin{array}{l}\text { Recordatorios sobre: tomar píldora, } \\
\text { aviso de retraso, próximo periodo }\end{array}$ & $\mathrm{X}$ & $\mathrm{X}$ & $\mathrm{X}$ & $\mathrm{X}$ & $\mathrm{X}$ & $\mathrm{X}$ & $\mathrm{X}$ & $\mathrm{X}$ \\
\hline Reporte e historial de ciclos & $\mathrm{X}$ & $\mathrm{X}$ & $\mathrm{X}$ & $\mathrm{X}$ & $\mathrm{X}$ & $\mathrm{X}$ & $\mathrm{X}$ & $\mathrm{X}$ \\
\hline Avisos sobre ventana de fertilidad & $\mathrm{X}$ & & $\mathrm{X}$ & $\mathrm{X}$ & & $\mathrm{X}$ & & $\mathrm{X}$ \\
\hline Enciclopedia e información del ciclo & $\mathrm{X}$ & $\mathrm{X}$ & & & $\mathrm{X}$ & & & \\
\hline Atención al cliente & $\mathrm{X}$ & & & & & & & $\mathrm{X}$ \\
\hline Cuéntaselo a tus amigas & $\mathrm{X}$ & & $\mathrm{X}$ & & & & $\mathrm{X}$ & $\mathrm{X}$ \\
\hline $\begin{array}{l}\text { Habla con tu médico sobre tu ciclo, } \\
\text { exportar documentos }\end{array}$ & & $\mathrm{X}$ & & $\mathrm{X}$ & & & & \\
\hline Duración típica de tu ciclo & & & $\mathrm{X}$ & $\mathrm{X}$ & $\mathrm{X}$ & $\mathrm{X}$ & $\mathrm{X}$ & $\mathrm{X}$ \\
\hline Información sobre anticonceptivos & $\mathrm{X}$ & $\mathrm{X}$ & & $\mathrm{X}$ & & & & $\mathrm{X}$ \\
\hline Trivias/juegos & & $\mathrm{X}$ & & & $\mathrm{X}$ & & $\mathrm{X}$ & \\
\hline Encuestas & & $\mathrm{X}$ & $\mathrm{X}$ & & $\mathrm{X}$ & & $\mathrm{X}$ & \\
\hline Foros/artículos & & $\mathrm{X}$ & & $\mathrm{X}$ & $\mathrm{X}$ & & $\mathrm{X}$ & $\mathrm{X}$ \\
\hline
\end{tabular}




\begin{tabular}{|c|c|c|c|c|c|c|c|c|}
\hline & Clue & Eve & Flo & $\begin{array}{l}\text { Calendario } \\
\text { Menstrual }\end{array}$ & Iperiod Lite & Period Tracker & Pink Pad & $\begin{array}{l}\text { Mi Calendario Ciclo } \\
\text { Menstrual }\end{array}$ \\
\hline Quiero quedar embarazada & & & $\mathrm{X}$ & & & $\mathrm{X}$ & $\mathrm{X}$ & \\
\hline Seguir mi embarazo & & & $\mathrm{X}$ & & & $\mathrm{X}$ & $\mathrm{X}$ & \\
\hline Consejos durante el periodo & & & $\mathrm{X}$ & & $\mathrm{X}$ & & & \\
\hline Probabilidad de embarazo & & & $\mathrm{X}$ & & $\mathrm{X}$ & & & \\
\hline $\begin{array}{l}\text { Fase mutua (tiempo entre ovación y el } \\
\text { comienzo de tu periodo }\end{array}$ & & & $\mathrm{X}$ & $\mathrm{X}$ & $\mathrm{X}$ & & & \\
\hline
\end{tabular}

Fuente: elaboración propia.

Tabla 4. Calificación y descripción del servicio

\begin{tabular}{|c|c|c|c|c|c|c|c|c|c|}
\hline & Natural Cycles & Clue & Eve & Flo & $\begin{array}{l}\text { Periodo } \\
\text { Calendario } \\
\text { Menstrual }\end{array}$ & Iperiod Lite & Period Tracker & Pink Pad & $\begin{array}{c}\text { Mi Calendario Ciclo } \\
\text { Menstrual }\end{array}$ \\
\hline \multicolumn{10}{|l|}{ Gratuito totalmente } \\
\hline $\begin{array}{l}\text { Pago por premium y } \\
\text { compras en la app }\end{array}$ & $\mathrm{X}$ & $\mathrm{X}$ & $\mathrm{X}$ & $\mathrm{X}$ & $\mathrm{X}$ & $\mathrm{X}$ & $\mathrm{X}$ & $\mathrm{X}$ & $\mathrm{X}$ \\
\hline Ios & $\mathrm{X}$ & $\mathrm{X}$ & $\mathrm{X}$ & $\mathrm{X}$ & $\mathrm{X}$ & $\mathrm{X}$ & $\mathrm{X}$ & $\mathrm{X}$ & $\mathrm{X}$ \\
\hline Android & & $\mathrm{X}$ & & $\mathrm{X}$ & $\mathrm{X}$ & $\mathrm{X}$ & $\mathrm{X}$ & $\mathrm{X}$ & \\
\hline Calificación & 4,6 & 4,9 & 4,6 & 4,8 & 5,0 & 4,8 & 4,8 & 4,7 & 4,7 \\
\hline Idiomas & 10 & 14 & 5 & 20 & 51 & 9 & 15 & 11 & 18 \\
\hline $\begin{array}{l}\text { Condiciones de uso y } \\
\text { política de privacidad }\end{array}$ & $\mathrm{X}$ & $\mathrm{X}$ & $X$ & $\mathrm{X}$ & $\mathrm{X}$ & $X$ & $X$ & $X$ & $X$ \\
\hline
\end{tabular}

Fuente: elaboración propia.

\section{Fase interactiva}

En esta sección se recopilaron datos relativos a la interacción del usuario con la aplicación en cuanto al flujo de datos personales, entre ellos datos personales sensibles relativos con aspectos íntimos de la salud sexual y reproductiva (tablas 5 y 6 ). 
Tabla 5. Datos personales: análisis interactivo

\begin{tabular}{|c|c|c|c|c|c|c|c|c|}
\hline & Clue & Eve & Flo & $\begin{array}{l}\text { Periodo Calendario } \\
\text { Menstrual }\end{array}$ & Iperiod & Period Tracker & Pink Pad & $\begin{array}{c}\text { Mi Calendario Ciclo } \\
\text { Menstrual }\end{array}$ \\
\hline Nombres y apellidos & $\mathrm{X}$ & $\mathrm{X}$ & & & & & $\mathrm{X}$ & \\
\hline Correo electrónico & $\mathrm{X}$ & $\mathrm{X}$ & & & $\mathrm{X}$ & $\mathrm{X}$ & & \\
\hline Contraseña & $\mathrm{X}$ & $\mathrm{X}$ & & & $\mathrm{X}$ & $\mathrm{X}$ & & \\
\hline Cuenta de Facebook & $\mathrm{X}$ & & & & $\mathrm{X}$ & $\mathrm{X}$ & $\mathrm{X}$ & \\
\hline Cuenta de Google & $\mathrm{X}$ & & & & & & & \\
\hline Tipo y flujo del sangrado & $\mathrm{X}$ & $\mathrm{X}$ & $\mathrm{X}$ & $\mathrm{X}$ & & $\mathrm{X}$ & & $\mathrm{X}$ \\
\hline $\begin{array}{l}\text { Síntomas, dolor físico (cabeza, } \\
\text { espalda, cólicos, senos) }\end{array}$ & $\mathrm{X}$ & $\mathrm{X}$ & $\mathrm{X}$ & $\mathrm{X}$ & & $\mathrm{X}$ & $\mathrm{X}$ & $\mathrm{X}$ \\
\hline $\begin{array}{l}\text { Emociones-sentimientos- } \\
\text { estrés, ansiedad }\end{array}$ & $\mathrm{X}$ & $\mathrm{X}$ & $\mathrm{X}$ & $\mathrm{X}$ & $\mathrm{X}$ & $\mathrm{X}$ & $\mathrm{X}$ & $\mathrm{X}$ \\
\hline Sueños, horas, insomnio & $\mathrm{X}$ & & $\mathrm{X}$ & $\mathrm{X}$ & $\mathrm{X}$ & $\mathrm{X}$ & $\mathrm{X}$ & \\
\hline $\begin{array}{l}\text { Acto sexual (sin protección o } \\
\text { con protección) }\end{array}$ & $\mathrm{X}$ & $\mathrm{X}$ & & $\mathrm{X}$ & & $\mathrm{X}$ & $\mathrm{X}$ & $\mathrm{X}$ \\
\hline Deseo sexual (alto o bajo) & $\mathrm{X}$ & $\mathrm{X}$ & $\mathrm{X}$ & $\mathrm{X}$ & & $\mathrm{X}$ & $\mathrm{X}$ & $\mathrm{X}$ \\
\hline Energía (alta, baja y exhausta) & $\mathrm{X}$ & $X$ & $\mathrm{X}$ & $\mathrm{X}$ & & $\mathrm{X}$ & & $\mathrm{X}$ \\
\hline Higiene íntima & $\mathrm{X}$ & & $\mathrm{X}$ & & $\mathrm{X}$ & & & \\
\hline Antojos & $\mathrm{X}$ & $\mathrm{X}$ & & $\mathrm{X}$ & & $\mathrm{X}$ & & \\
\hline Cabello & $\mathrm{X}$ & & & & & & & \\
\hline Piel & $\mathrm{X}$ & & & & & & & \\
\hline Digestión y sueño & $\mathrm{X}$ & & & $\mathrm{X}$ & & $\mathrm{X}$ & & \\
\hline Ejercicio & $\mathrm{X}$ & $\mathrm{X}$ & $\mathrm{X}$ & & $\mathrm{X}$ & $\mathrm{X}$ & $\mathrm{X}$ & \\
\hline $\begin{array}{l}\text { Método anticonceptivo } \\
\text { frecuente }\end{array}$ & $\mathrm{X}$ & $\mathrm{X}$ & $\mathrm{X}$ & $\mathrm{X}$ & & & & $\mathrm{X}$ \\
\hline Duración del periodo & $\mathrm{X}$ & $\mathrm{X}$ & $\mathrm{X}$ & $\mathrm{X}$ & $\mathrm{X}$ & $\mathrm{X}$ & $\mathrm{X}$ & $\mathrm{X}$ \\
\hline Regularidad del ciclo & $\mathrm{X}$ & $\mathrm{X}$ & $\mathrm{X}$ & $\mathrm{X}$ & $\mathrm{X}$ & $\mathrm{X}$ & $\mathrm{X}$ & $\mathrm{X}$ \\
\hline
\end{tabular}




\begin{tabular}{|c|c|c|c|c|c|c|c|c|}
\hline & Clue & Eve & Flo & $\begin{array}{l}\text { Periodo Calendario } \\
\text { Menstrual }\end{array}$ & Iperiod & Period Tracker & Pink Pad & $\begin{array}{c}\text { Mi Calendario Ciclo } \\
\text { Menstrual }\end{array}$ \\
\hline $\begin{array}{l}\text { Fecha de inicio de la } \\
\text { anticoncepción }\end{array}$ & $\mathrm{X}$ & $X$ & & & & & & \\
\hline $\begin{array}{l}\text { Estado civil, tipo de relación } \\
\text { (amigo, novio o casada) }\end{array}$ & & $X$ & $\mathrm{X}$ & & & & & \\
\hline Fecha de nacimiento & & $\mathrm{X}$ & $\mathrm{X}$ & & & $\mathrm{X}$ & & \\
\hline Altura & & $\mathrm{X}$ & & & & & & \\
\hline Peso & & $\mathrm{X}$ & $\mathrm{X}$ & $\mathrm{X}$ & $\mathrm{X}$ & $\mathrm{X}$ & $\mathrm{X}$ & $\mathrm{X}$ \\
\hline Fecha de último ciclo & $\mathrm{X}$ & $\mathrm{X}$ & $\mathrm{X}$ & $\mathrm{X}$ & $\mathrm{X}$ & $\mathrm{X}$ & $\mathrm{X}$ & $\mathrm{X}$ \\
\hline $\begin{array}{l}\text { Cambios en tu bienestar } \\
\text { durante tu ciclo }\end{array}$ & $\mathrm{X}$ & $X$ & $\mathrm{X}$ & $\mathrm{X}$ & $\mathrm{X}$ & & & \\
\hline Manchado intermenstrual & & & $\mathrm{X}$ & & $\mathrm{X}$ & & $\mathrm{X}$ & \\
\hline $\begin{array}{l}\text { Información de dieta e } \\
\text { hidratación }\end{array}$ & & & $X$ & $\mathrm{X}$ & & $\mathrm{X}$ & & \\
\hline $\begin{array}{l}\text { Frecuencia de fiestas eventos- } \\
\text { alcohol }\end{array}$ & & & $\mathrm{X}$ & & & & & \\
\hline Vicios, cigarrillos & & & $\mathrm{X}$ & & & & & \\
\hline $\begin{array}{l}\text { Con qué frecuencia te haces la } \\
\text { prueba del PAP y autoexamen } \\
\text { de seno }\end{array}$ & & & $\mathrm{X}$ & $\mathrm{X}$ & & & & $\mathrm{X}$ \\
\hline $\begin{array}{l}\text { Con qué frecuencia visitas el } \\
\text { ginecólogo }\end{array}$ & & & $\mathrm{X}$ & & & & $\mathrm{X}$ & \\
\hline Acné & $\mathrm{X}$ & & $\mathrm{X}$ & $\mathrm{X}$ & $\mathrm{X}$ & $\mathrm{X}$ & & $\mathrm{X}$ \\
\hline Hijos & & & $\mathrm{X}$ & & & & & \\
\hline Enfermedades crónicas & & & $\mathrm{x}$ & & & & & \\
\hline
\end{tabular}

Fuente: elaboración propia. 


\section{Tabla 6. Algunos comentarios importantes}

\begin{tabular}{|c|c|}
\hline Natural Cycles & $\begin{array}{l}\text { Es la primera aplicación móvil reconocida por la FDA como } \\
\text { método anticonceptivo, porque utiliza un dispositivo médico } \\
\text { certificado para medir la temperatura basal. }\end{array}$ \\
\hline Clue & $\begin{array}{l}\text { Recolecta datos personales que luego de ser anonimizados } \\
\text { se usan para fines de investigación científica y biomédica. } \\
\text { Entre las investigaciones más destacadas se encuentran las } \\
\text { siguientes: } \\
\text { - "Evolución, menstruación y síndrome premenstrual", } \\
\text { Universidad de Oxford. } \\
\text { - "El ciclo menstrual como signo vital", Universidad de } \\
\text { Stanford. } \\
\text { - "Sexo y tecnología: perspectivas femeninas sobre el uso del } \\
\text { condón entre muchos otros", Universidad de Indiana. }\end{array}$ \\
\hline Eve & $\begin{array}{l}\text { Una de las problemáticas de Eve es que, una vez cancelada la } \\
\text { cuenta, la aplicación mantiene la información y solo puede ser } \\
\text { eliminada bajo solicitud del titular. }\end{array}$ \\
\hline Flo & $\begin{array}{l}\text { Flo enfatiza en la eliminación, supresión y eliminación de los } \\
\text { datos personales a través de un correo soporte. }\end{array}$ \\
\hline Iperiod & $\begin{array}{l}\text { Todos los datos que se ingresen en la aplicación se copiarán } \\
\text { periódicamente en los servidores dewinkpass a través de una } \\
\text { conexión cifrada y se almacenarán cifrados en el servidor, lo } \\
\text { que garantiza la privacidad. }\end{array}$ \\
\hline Period Tracker & $\begin{array}{l}\text { Para la eliminación de los datos proporcionados, basta con } \\
\text { eliminar la cuenta. }\end{array}$ \\
\hline My Cycles & $\begin{array}{l}\text { Esta aplicación acepta la divulgación de la información } \\
\text { personal de salud a las compañías, agentes, contratistas, } \\
\text { proveedores de servicios u otras personas involucradas para } \\
\text { realizar funciones en su nombre. }\end{array}$ \\
\hline $\begin{array}{l}\text { Mi Calendario } \\
\text { Ciclo Menstrual }\end{array}$ & $\begin{array}{l}\text { Adopta todas las medidas técnicas y organizativas para } \\
\text { prevenir la pérdida, uso indebido y alteración de los datos } \\
\text { personales bajo su control y, en algunos casos, también puede } \\
\text { adoptar datos métodos de encriptación. }\end{array}$ \\
\hline
\end{tabular}

Fuente: elaboración propia.

Cabe recordar que el análisis de las políticas de privacidad corresponde a la segunda fase de investigación: 
- Guía técnica del Instituto Nacional de Vigilancia de Medicamentos y Alimentos (Invima), que permita conceptualizar las aplicaciones móviles como dispositivos médicos.

- Hacer hincapié en aquellas que implican un alto riesgo para la vida y salud el usuario.

- Reforzar el sistema de protección al consumidor en lo relativo a la garantía y veracidad de la información suministrada en salud.

- Expedir un reglamento de aplicaciones móviles en salud.

- Aplicar los criterios de la FDA en el ámbito del Invima.

\section{Obstetricia}

Se realizó un análisis técnico-interactivo, donde en una misma gráfica se evidencian las funciones y, por consiguiente, los datos sensibles recolectados (tabla 7). 
Tabla 7. Tabla de funciones y recolección de datos

\begin{tabular}{|c|c|c|c|c|c|c|c|c|}
\hline Funciones & Bebé a Bordo & MAMABCD & $\begin{array}{c}\text { Embarazo y Bebé } \\
\text { Día a Día }\end{array}$ & Diario del Bebé & $\begin{array}{c}\text { Sanitas/ } \\
\text { Embarazo }\end{array}$ & Baby Center & $\begin{array}{l}\text { Mi Embarazo } \\
\text { al Día }\end{array}$ & Embarazo + \\
\hline Chat médico y enfermeras & $\mathrm{X}$ & $\mathrm{X}$ & & & & & & \\
\hline $\begin{array}{l}\text { Almacenamiento de historial } \\
\text { clínico }\end{array}$ & & $\mathrm{X}$ & & & $\mathrm{X}$ & & & \\
\hline $\begin{array}{l}\text { Herramienta para programar } \\
\text { citas y controles de embarazo }\end{array}$ & & $\mathrm{X}$ & & $\mathrm{X}$ & $\mathrm{X}$ & & & \\
\hline $\begin{array}{l}\text { Revisión periódica de } \\
\text { medicamentos }\end{array}$ & & $\mathrm{X}$ & & & & & & $\mathrm{X}$ \\
\hline $\begin{array}{l}\text { Muestras correspondientes a } \\
\text { las tomas de presión arterial, } \\
\text { glucometría y peso }\end{array}$ & $\mathrm{X}$ & $\mathrm{X}$ & & & $\mathrm{X}$ & & $\mathrm{X}$ & $\mathrm{X}$ \\
\hline $\begin{array}{l}\text { Botón de emergencia/ } \\
\text { geolocalización/ambulancia/ } \\
\text { familiares }\end{array}$ & $\mathrm{X}$ & $\mathrm{X}$ & & & & & & \\
\hline Baby shower & & $\mathrm{X}$ & & & & & & \\
\hline Fotos & $\mathrm{X}$ & $\mathrm{X}$ & $\mathrm{X}$ & $\mathrm{X}$ & $\mathrm{X}$ & $\mathrm{X}$ & $\mathrm{X}$ & $\mathrm{X}$ \\
\hline Nombres para bebé & $\mathrm{X}$ & $\mathrm{X}$ & $\mathrm{X}$ & & $\mathrm{X}$ & $\mathrm{X}$ & $\mathrm{X}$ & $\mathrm{X}$ \\
\hline Signos de alerta & $\mathrm{X}$ & $\mathrm{X}$ & & & & & & \\
\hline $\begin{array}{l}\text { Espacio información/imágenes } \\
\text { interactivas }\end{array}$ & $\mathrm{X}$ & $\mathrm{X}$ & $\mathrm{X}$ & $\mathrm{X}$ & $\mathrm{X}$ & $\mathrm{X}$ & $\mathrm{X}$ & $\mathrm{X}$ \\
\hline Registro de la panza & $\mathrm{X}$ & & & & & & & \\
\hline Bebé primer mes & $\mathrm{X}$ & & & & & $\mathrm{X}$ & $\mathrm{X}$ & \\
\hline $\begin{array}{l}\text { Contador de patadas/ } \\
\text { contracciones }\end{array}$ & $\mathrm{X}$ & $\mathrm{X}$ & $\mathrm{X}$ & $\mathrm{X}$ & $\mathrm{X}$ & & $\mathrm{X}$ & $\mathrm{X}$ \\
\hline Calculadora fecha de parto & $\mathrm{X}$ & $\mathrm{X}$ & $\mathrm{X}$ & $\mathrm{X}$ & $\mathrm{X}$ & $\mathrm{X}$ & $\mathrm{X}$ & $\mathrm{X}$ \\
\hline Información médica & & $\mathrm{X}$ & $\mathrm{X}$ & & & $\mathrm{X}$ & & $\mathrm{X}$ \\
\hline Foros virtuales & & & & & & $\mathrm{X}$ & & \\
\hline Diario personal & & & & & & & $\mathrm{X}$ & $\mathrm{X}$ \\
\hline
\end{tabular}

Fuente: elaboración propia. 


\section{Análisis técnico-funcional: aplicaciones en ginecobstetricia}

A través de una revisión meramente sistemática se pueden sacar las siguientes conclusiones analíticas:

En cuanto a la dimensión técnica:

a. E1 $100 \%$ de las aplicaciones ginecológicas se autoconsideran calendarios menstruales, pues permiten seguir la duración del periodo, y en ningún momento se autoconcibieron como métodos anticonceptivos.

b. El $100 \%$ de las aplicaciones ginecológicas permiten seguir la regularidad del ciclo menstrual y la duración de este, así como el nivel de flujo de sangrado.

c. El $100 \%$ de las aplicaciones permiten medir la duración del periodo para fines de alerta del siguiente.

d. E1 100\% de las aplicaciones ginecológicas permiten llevar el registro de todos los ciclos.

e. E1 $75 \%$ de las aplicaciones ginecológicas permiten registrar aspectos relacionados con el sueño.

f. El 25\% de las aplicaciones ginecológicas permite registrar citas al ginecólogo.

g. La aplicación clue es la mejor calificada pero, paradójicamente, es la que más datos personales recolecta y es la que ofrece mayor número de funcionalidades.

h. El 100\% de las aplicaciones ginecológicas recolectan un flujo de datos personales, en su gran mayoría, asociadas con temas de salud en sus diversas manifestaciones.

i. E1 50\% de las aplicaciones ginecológicas suministra información educativa sobre anticonceptivos.

j. Las aplicaciones obstétricas no se muestran en primera medida como aplicaciones de telemedicina, sino como aplicaciones de teleeducación, pues sus funciones 
están dirigidas a informar a la mujer de los aspectos más relevantes del embarazo buscando acompañar a la madre en su proceso de gestación. Se destacan aspectos como el recordatorio en medicamentos, las guías en salud, la posibilidad de comunicarse con un médico a distancia, registrar la presión arterial, el número de contracciones, entre otras funciones.

k. El 100\% de las aplicaciones obstétricas permite registrar la evolución del embarazo para calcular la fecha estimada de parto.

1. El $100 \%$ de las aplicaciones obstétricas suministran información sobre las semanas de embarazo y permiten llevar imágenes interactivas de la evolución fetal. m. El 87\% permite contar y registrar las patadas y las contracciones.

n. E125\% cuenta con botón de emergencia para llamar a una ambulancia.

ñ. El 25\% cuentan con señales de alarma/alerta.

o. Todas las aplicaciones obstétricas tienen como factor común el suministro de información y el calcular la fecha de parto.

En cuanto a la dimensión interactiva:

a. E1 100\% de las aplicaciones ginecológicas recolecta datos personales sensibles: se tiene que todas las analizadas recolectan datos relacionados con emociones, sentimientos y respuestas hormonales de las usuarias.

b. El 100\% de las aplicaciones analizadas recolecta imágenes de la madre y del bebé o, al menos, permiten hacerlo. 
c. E1 87\% de las aplicaciones ginecológicas analizadas recolecta datos relativos a la vida y actividad sexual de la mujer, así como información sobre los métodos anticonceptivos que utiliza.

d. El 87\% recolecta datos relativos al peso corporal de la mujer.

e. Solo clue busca recopilar datos relativos al fenotipo de la mujer (cabello, altura, color de ojos, tez, entre otras).

f. El 100\% recoge datos relativos a los síntomas/dolor físico/psíquico asociado con el ciclo menstrual o al periodo de embarazo.

Del anterior análisis sistemático, se advierten dos riesgos fundamentales (tabla 8).

\section{Tabla 8. Tabla de riesgos}

\begin{tabular}{|c|c|}
\hline \multicolumn{2}{|r|}{ Aplicaciones ginecológicas } \\
\hline $\begin{array}{l}\text { Riesgo a la } \\
\text { confidencialidad }\end{array}$ & $\begin{array}{l}\text { Recolectan un sinfín de datos personales de toda índole, y en algunos } \\
\text { casos sin una política de privacidad idónea para el efecto. } \\
\text { En algunos casos recolectan datos que podrían considerarse } \\
\text { innecesarios o que no son proporcionalidades con las finalidades } \\
\text { funcionales de la aplicación (datos fenotípicos, como el color de los } \\
\text { ojos, el pelo, entre otros). }\end{array}$ \\
\hline Riesgo a la salud & $\begin{array}{l}\text { En principio, no existe un control estatal de la información que se } \\
\text { introduce en dichas plataformas, lo que puede inducir a error al usuario. } \\
\text { Ninguna de las plataformas analizadas cuenta con licencia o } \\
\text { autorización de alguna autoridad en Colombia. }\end{array}$ \\
\hline \multicolumn{2}{|r|}{ Aplicaciones obstétricas } \\
\hline $\begin{array}{l}\text { Riesgo a la } \\
\text { confidencialidad }\end{array}$ & $\begin{array}{l}\text { Recolectan un sinfín de datos personales de toda índole, pero lo más } \\
\text { preocupante es la imagen y los datos personales del menor. }\end{array}$ \\
\hline Riesgo a la salud & $\begin{array}{l}\text { Se muestran como plataformas de acompañamiento telemédico, y no } \\
\text { como dispositivos médicos que impliquen una injerencia en el cuerpo } \\
\text { de la mujer. Sin embargo, en principio no existe un control estatal de la } \\
\text { información que allí se suministra. }\end{array}$ \\
\hline
\end{tabular}

Fuente: elaboración propia. 


\section{Matriz de riesgo en Colombia}

A fin de establecer si en Colombia existe un control efectivo e idóneo a los riesgos mencionados, se evaluaron los índices de mitigación de los riesgos y contingencias a la luz del sistema jurídico colombiano. También se evaluaron los estándares de control y se identificaron los principales vacíos que deben regularse a partir de una política pública integral.

Aquí se entiende por riesgo "toda probabilidad de lesión a un bien jurídico protegido o tutelado" que requiere medidas para evitar su concreción. En consecuencia, nos enfocamos en dos riesgos fundamentales: a la confidencialidad y a la salud, tomando como base el enfoque norteamericano fundado en el riesgo y el enfoque español sustentado en los datos personales.

\section{Riesgo a la confidencialidad en las aplicaciones ginecológicas y obstétricas}

Tal y como se evidenció en el análisis interactivo, las aplicaciones ginecológicas recolectan datos relacionados con las siguientes áreas: 1) aspectos psicosociales de la mujer; 2) actividad sexual de la mujer; 3 ) enfermedades previas y síntomas del ciclo menstrual; 4) antecedentes clínicos y tratamientos médicos; 5) sueño, ejercicio, vicios y actividades de la vida diaria, y 6) anticoncepción, planificación, ovulación y menstruación, asuntos relacionados con información prenatal, natal, posnatal y neonatal.

La protección jurídica de los datos en salud en Colombia se encuentra tutelada a partir de la Ley 1581 de 2012. Bajo la categoría de datos sensibles, se encuentran todos aquellos relacionados con la intimidad del titular o cuyo uso indebido puede generar situaciones de discriminación. Estos 
datos comprenden cualquier información que se refiera a la salud física, sexual y psíquica de una persona y, por ende, tiene una tutela reforzada. El artículo 5 de la Ley 1581 de 2012 dispone:

Art 5. Datos sensibles. Para los propósitos de la presente ley, se entiende por datos sensibles aquellos que afectan la intimidad del titular o cuyo uso indebido puede generar su discriminación, tales como aquellos que revelen el origen racial o étnico, la orientación política, las convicciones religiosas o filosóficas, la pertenencia a sindicatos, organizaciones sociales, de derechos humanos o que promueva intereses de cualquier partido político o que garanticen los derechos y garantías de partidos políticos de oposición así como los datos relativos a la salud, a la vida sexual y los datos biométricos.

En todos estos casos, los responsables y encargados de los datos personales deben obrar con mayor diligencia, utilizando mayores medidas de seguridad, restricción de acceso y confidencialidad demostrada con miras a proteger cualquier tipo de dato personal. Frente al dato sensible, la Superintendencia de Industria y Comercio ha construido el principio de responsabilidad reforzada, el cual implica que el tratamiento de datos personales no solamente pone en riesgo el derecho al habeas data, sino el buen nombre, la intimidad personal, la salud y la dignidad humana; por lo que se requieren medidas reforzadas de seguridad para evitar su indebido tratamiento (sentencias C-748 de 2011 y T-114 de 2018). 
Por otro lado, el dato personal se refiere a toda información que puede "determinar" o hacer "determinable" a su titular, por lo que siempre que se mantenga en manos del responsable o encargado implica un riesgo potencial que requiere obligaciones adicionales de protección, más aún cuando se relaciona con asuntos sexuales y reproductivos.

De igual forma, la Corte Constitucional ha reconocido la categoría de datos sensibles como los datos relativos a la salud, a la vida sexual y los datos biométricos (sentencia T-114 de 2018). A partir del derecho a la intimidad, se protege cualquier intromisión en la esfera interna o privada que la persona; por ende, los datos relacionados con la salud (siendo íntimos) deben tener circulación restringida, esto es, solo puede ejercer tratamiento de estos mediando consentimiento libre, previo, expreso e informado del titular (sentencias T-340 de 1993, C-913 de 2010 y T-414 de 1992).

A efectos de proteger datos sensibles relativos a la salud y la vida sexual, el sistema jurídico colombiano dotó a la Superintendencia de Industria y Comercio de competencia para conocer asuntos relativos a infracciones del habeas data, la cual, a través del procedimiento administrativo sancionatorio, puede hacer valer los principios estatutarios en la materia. Es importante recordar los principios que regulan la ley de habeas data, pues son criterios rectores para el recaudo y tratamiento de datos personales frente a todos aquellos responsables y encargados de bases de datos. Entre los más destacados se encuentran: 1) principio de finalidad, cuyo tratamiento debe obedecer a una finalidad legítima de acuerdo con la Constitución y la ley; 2) libertad, donde el tratamiento de datos solo puede ejercerse con el consentimiento previo, expreso e informado del titular, y no podrá haber divulgación sin 
previa autorización; 3) veracidad, aquí la información sujeta a tratamiento debe ser veraz, completa, exacta y actualizada, comprobable y comprensible; 4) circulación restringida, donde solo personas autorizadas por el titular podrá hacer el tratamiento de datos, y 5) necesidad, pues los datos deben estar vinculados a la finalidad legítima y debe evitarse recolectar datos innocuos o innecesarios.

Si bien no existe una mención expresa del habeas data en ámbitos de salud móvil, sí se cuenta con la decisión hito de la Superintendencia de Industria y Comercio, emitida a través de la Resolución 39298 del 21 de junio de 2016. Allí impuso dos sanciones pecuniarias a Colmédica Medicina Prepagada sas, que ascienden a la suma de 1.034.182.500 de pesos, pues se acreditó que la entidad divulgó en su página web información personal de más de treinta usuarios (datos relativos a patologías, diagnósticos y reportes de exámenes médicos). Bajo la misma línea, en el ámbito obstétrico, la Superintendencia sancionó a la Sociedad Repcord de Colombia S.A., encargada del procesamiento y preservación de células madre, entidad que se enteró de que la reclamante se encontraba en estado de embarazo y, por tal motivo, procedió a contactarla para ofrecerle servicios comerciales. La razón de la decisión se fundó en la violación al deber de solicitar la autorización para el tratamiento de datos médicos y obstétricos, por lo que se le impuso una multa de 123.200.000 de pesos.

No puede olvidarse que las aplicaciones manejadas por personas naturales o jurídicas se enmarcan en la categoría de bases de datos nacionales, de conformidad con la Ley 1581 de 2012, pues sistematizan y archivan datos sensibles en el territorio colombiano y, por ende, son susceptibles de control 


\section{por parte de la Superintendencia de Industria y Comercio. No obstante lo anterior, la tabla 9 evidencia vacíos normativos.}

Tabla 9. Tabla de vacíos y propuestas de solución

\begin{tabular}{|l|l|l|}
\hline \multicolumn{1}{|c|}{ Vacío } & \multicolumn{1}{|c|}{ Explicación } & \multicolumn{1}{c|}{ Propuesta de solución } \\
\hline $\begin{array}{l}\text { No existe una ley } \\
\text { de babeas data } \\
\text { sectorizada en el } \\
\text { ámbito de la salud. }\end{array}$ & $\begin{array}{l}\text { El dato en salud se encuentra } \\
\text { protegido bajo el concepto } \\
\text { jurídico de dato sensible. } \\
\text { Sin embargo, existe un } \\
\text { desarrollo muy reducido } \\
\text { (legislativo y jurisprudencial) } \\
\text { en la conceptualización y } \\
\text { caracterización del dato en salud. }\end{array}$ & $\begin{array}{l}\text { Proyecto de ley sectorial } \\
\text { de habeas data en salud. } \\
\text { Guía explicativa } \\
\text { sobre el dato en } \\
\text { salud, especificando } \\
\text { sus características } \\
\text { particulares y su } \\
\text { protección especializada. }\end{array}$ \\
\hline $\begin{array}{l}\text { Falta de } \\
\text { reconocimiento } \\
\text { del dato } \\
\text { ginecobstétrico. }\end{array}$ & $\begin{array}{l}\text { No existe a la fecha un } \\
\text { reconocimiento legal del dato } \\
\text { ginecobstétrico como una } \\
\text { categoría especial de dato en } \\
\text { salud. La Ley 1581 iguala el dato } \\
\text { en salud al dato relativo a la vida } \\
\text { sexual. }\end{array}$ & $\begin{array}{l}\text { Guía explicativa del } \\
\text { babeas data en salud, } \\
\text { especificando los } \\
\text { escenarios ginecológicos } \\
\text { y obstétricos y su relación } \\
\text { con los derechos sexuales } \\
\text { y reproductivos. }\end{array}$ \\
\hline $\begin{array}{l}\text { No existe una guía } \\
\text { para políticas de } \\
\text { privacidad en el } \\
\text { ámbito virtual. }\end{array}$ & $\begin{array}{l}\text { Los avisos legales de privacidad } \\
\text { son particulares y específicos, } \\
\text { pues se despliegan en el ámbito } \\
\text { virtual. }\end{array}$ & $\begin{array}{l}\text { Guía de instrucciones } \\
\text { para avisos legales de } \\
\text { privacidad en escenarios } \\
\text { virtuales. }\end{array}$ \\
\hline $\begin{array}{l}\text { No existen sellos de } \\
\text { de medical apps. }\end{array}$ & $\begin{array}{l}\text { Hasta el momento no existe } \\
\text { un sello de calidad en materia } \\
\text { te seguridad informática y } \\
\text { tratamiento de datos personales, } \\
\text { que califique a las medical apps } \\
\text { relacionadas con asuntos sexuales } \\
\text { y reproductivos. }\end{array}$ & $\begin{array}{l}\text { Concederle validez al } \\
\text { sello de calidad español, } \\
\text { internacional. }\end{array}$ \\
\hline
\end{tabular}

Fuente: elaboración propia.

\section{Riesgo a la salud}

En cuanto al riesgo para la salud, el sector ha sido ajeno a los avances tecnológicos en materia de aplicaciones móviles. Incluso preocupa que la Ley 1419 de 2010, denominada 
"Ley de telemedicina", la restringe a prestación de servicios de salud a distancia prestados por profesionales de la salud. Esta ley dispone lo siguiente:

Art 2. Definiciones:

Telesalud: es el conjunto de actividades relacionadas con la salud, servicios y métodos, los cuales se llevan a cabo a distancia con la ayuda de las tecnologías de la información y telecomunicaciones. Incluye, entre otras, la Telemedicina y la Teleeducación en salud.

Telemedicina: es la provisión de servicios de salud a distancia en los componentes de promoción, prevención, diagnóstico, tratamiento y rehabilitación, por profesionales de la salud que utilizan tecnologías de la información y la comunicación, que les permiten intercambiar datos con el propósito de facilitar el acceso y la oportunidad en la prestación de servicios a la población que presenta limitaciones de oferta, de acceso a los servicios o de ambos en su área geográfica.

Lo anterior implica que quedan por fuera de la definición legal los servicios de telesalud desarrollados por terceros particulares, nacionales o extranjeros, que no son profesionales de la salud, pero prestan de forma industrial y comercial servicios de telesalud. Varias de las aplicaciones móviles en salud escapan al ámbito médico sanitario para ofertarse en el mercado digital.

Así mismo, el artículo 245 de la Ley 100 de 1993 determinó que le corresponde al Gobierno nacional reglamentar el régimen de registros sanitarios, vigilancia y control de los productos sanitarios, entre ellos los dispositivos médicos para 
uso humano. Por dispositivo médico se entiende "cualquier instrumento, aparato, máquina, software, equipo biomédico u otro artículo similar o relacionado, utilizado solo o en combinación, incluyendo sus componentes, partes, accesorios y programas informáticos que intervengan en su correcta aplicación" para fines de diagnóstico, prevención y supervisión de una enfermedad. E1 Decreto 4725 de 2005 determina que los dispositivos médicos para uso humano son controlables por el Invima, y la clasificación del riesgo la realizará el fabricante teniendo en cuenta los riesgos potenciales relacionados con el uso y el posible fracaso de los dispositivos móviles. A saber, los riesgos se clasifican como los registra la tabla 10 .

Tabla 10. Clasificación de los riesgos

\begin{tabular}{|l|l|}
\hline $\begin{array}{l}\text { Clase I: } \\
\text { Bajo riesgo }\end{array}$ & $\begin{array}{l}\text { Dispositivos no destinados a proteger o mantener la vida o para } \\
\text { un uso de importancia especial en la prevención del deterioro de } \\
\text { la salud humana. Por ende, no representan un riesgo potencial no } \\
\text { razonable de enfermedad o lesión. }\end{array}$ \\
\hline $\begin{array}{l}\text { Clase II: } \\
\text { Riesgo moderado }\end{array}$ & $\begin{array}{l}\text { Sujetos a controles especiales en la fase de fabricación para } \\
\text { demostrar su seguridad y efectividad. }\end{array}$ \\
\hline $\begin{array}{l}\text { Clase III: } \\
\text { Riesgo alto }\end{array}$ & $\begin{array}{l}\text { Sujetos a controles especiales en el diseño y fabricación para } \\
\text { demostrar su seguridad y efectividad. }\end{array}$ \\
\hline $\begin{array}{l}\text { Clase Iv: } \\
\text { Riesgo muy alto }\end{array}$ & $\begin{array}{l}\text { Dispositivos médicos destinados a proteger o mantener la vida } \\
\text { o para un uso de importancia sustancial en la prevención del } \\
\text { deterioro de la salud humana, o si su uso presenta un riesgo } \\
\text { potencial de enfermedad o lesión. }\end{array}$ \\
\hline
\end{tabular}

Fuente: artículo 15 del Decreto 4725 de 2005.

Para controlar los riesgos, el Invima ejerce una supervisión de tecnovigilancia sobre los dispositivos. Esa potestad administrativa se ha entendido como el conjunto de actividades que tienen por objeto la "identificación y la 
cualificación de eventos e incidentes adversos asociados con los dispositivos médicos, así como la identificación de los factores de riesgo asociados a estos, con base en la notificación, registro y evaluación sistemática” (Invima, 2012). Ese programa se encuentra normado por la Resolución 4816 de 2008, donde se configura una estrategia de vigilancia poscomercialización y evaluación sanitaria, para la identificación y evaluación de la información de seguridad relacionada con el uso de los dispositivos médicos. A la fecha no existe un estudio - desplegado en el marco de la tecnovigilanciatendiente a evaluar las aplicaciones móviles en salud. Sin embargo, de la definición de dispositivo médico se extrae que también son considerados así el software o combinación de algoritmos, muy propios de las aplicaciones movibles. Sin embargo, no existe una mención expresa a las medical apps y, en consecuencia, no existe un estudio tendiente a clasificar las aplicaciones móviles ginecobstétricas en alguna de estas categorías de riesgo.

De igual forma, no se ha insertado una definición legal de forma expresa y regulada, estilo FDA, destinada a conceptualizar las aplicaciones móviles como dispositivos médicos, lo que dificulta la aplicación de la función administrativa regida por el principio de legalidad. Por lo tanto, estamos ante un vacío legal evidente que requiere ser complementado con nueva legislación y aportes reglamentarios emitidos por el Invima.

Se concluye que en Colombia las medical apps aún no se encuentran conceptualizadas desde el punto de vista del sector de la salud; por ende, todavía no son susceptibles de control por parte del Invima ni, mucho menos, tienen una mención en la Ley 1419 de 2010, que regula la telemedicina 
en Colombia. En la tabla 11 se presentan los vacíos y las propuestas de solución.

Tabla 11. Tabla de vacíos y propuestas de solución

\begin{tabular}{|l|l|l|}
\hline \multicolumn{1}{|c|}{ Vacío } & \multicolumn{1}{|c|}{ Explicación } & \multicolumn{1}{c|}{ Propuesta de solución } \\
\hline $\begin{array}{l}\text { No existe una } \\
\text { definición de } \\
\text { aplicación móvil } \\
\text { en salud. }\end{array}$ & $\begin{array}{l}\text { Así como la FDA clasificó las aplicaciones } \\
\text { móviles en salud como dispositivos } \\
\text { médicos, el Estado colombiano debe } \\
\text { hacerlo en la misma categoría, con miras } \\
\text { a tener un control sobre aquellas que } \\
\text { implican un riesgo alto a la vida o salud } \\
\text { del paciente. }\end{array}$ & $\begin{array}{l}\text { Guía técnica del Invima que } \\
\text { permita conceptualizar las } \\
\text { aplicaciones móviles como } \\
\text { dispositivos médicos. }\end{array}$ \\
\hline $\begin{array}{l}\text { Falta de } \\
\text { categorización } \\
\text { de riesgos. }\end{array}$ & $\begin{array}{l}\text { Hasta el día de hoy, no existe una } \\
\text { política pública tendiente a evaluar } \\
\text { cuáles medical apps implican un alto } \\
\text { riesgo a la vida y salud del paciente. }\end{array}$ & $\begin{array}{l}\text { Poner el relieve en aquellas } \\
\text { que implican un alto riesgo } \\
\text { para la vida y salud el usuario. }\end{array}$ \\
\hline $\begin{array}{l}\text { Falta de } \\
\text { categorización } \\
\text { en seguridad. }\end{array}$ & $\begin{array}{l}\text { Hasta el día de hoy, no existe un control } \\
\text { de farmacovigilancia de las aplicaciones } \\
\text { móviles. }\end{array}$ & $\begin{array}{l}\text { Reforzar el sistema de } \\
\text { protección al consumidor } \\
\text { en lo relativo a la garantía y } \\
\text { veracidad de la información } \\
\text { suministrada en salud. }\end{array}$ \\
\hline
\end{tabular}

Fuente: elaboración propia.

\section{Conclusión}

La ausencia de un régimen de tecnovigilancia adecuado, similar al de la FDA y la legislación española, hace que los controles genéricos aplicables al ámbito de la salud sean insuficientes para contrarrestar el fenómeno de las medical apps. En consecuencia, la falta de reconocimiento legal del fenómeno de la salud móvil y el vacío jurídico evidenciado en la Ley 1419 de 2010 ponen de manifiesto que la temática aún no hace parte de la agenda política. Sumado a lo anterior, la Ley 1581 de 2012 ya comienza a mostrarse insuficiente, pues requiere complementarse con nuevas normas y guías 
sectoriales que permitan ejercer un control mucho más concreto y eficaz bajo un criterio de dato ginecobstétrico.

En consecuencia, urge subsanar el riesgo a la salud y a los datos personales desde un enfoque integral que contenga: primero, un enfoque fundado en el riesgo, que permita llevar a cabo labores similares a las de la FDA en Estados Unidos, en el cual se exija graduar las aplicaciones en aquellas de alto, mediano y menor riesgo para fines de tecnovigilancia. Segundo, un enfoque fundado en la protección de datos personales sensibles que, a través de sellos de calidad, auditorías o controles periódicos, permitan establecer cuáles son las aplicaciones respetuosas con la información personal de la mujer.

Como primer paso, se hace necesario incluir dentro del concepto amplio de telesalud el fenómeno de las medical apps, así como sentar definiciones, políticas de supervisión, facultades de tecnovigilancia y recursos administrativos que permitan cuestionar la seguridad, la calidad y la confidencialidad de las aplicaciones móviles en el ámbito ginecobstétrico.

Para ello se recomienda dotar al Invima de facultades para analizar los atributos de calidad en medical apps desde una perspectiva de política pública, donde exista participación de los profesionales de la salud, facultades de medicina, estudiantes y mujeres usuarias, a fin de construir un proceso dialéctico que derive en la inclusión del fenómeno en la agenda nacional.

Para lograr todos esos objetivos, recomendamos aplicar la estrategia de validación de aplicaciones móviles de salud creada por Ramírez, Guillén y Cifuentes (2016), cuyo objetivo es controlar aplicaciones móviles, y es el modelo idóneo para construir un sello de calidad nacional que tenga en cuenta las características presentadas en la tabla 12. 
Tabla 12. Características para validar aplicaciones móviles de salud

\begin{tabular}{|l|l|}
\hline $\begin{array}{l}\text { Control sobre } \\
\text { el rendimiento }\end{array}$ & $\begin{array}{l}\text { Verificación de pruebas de rendimiento y eficacia que permitan } \\
\text { acreditar la capacidad de la app para funcionar adecuadamente en } \\
\text { el objetivo de sus funciones. Esto es, que las aplicaciones realmente } \\
\text { sirvan como calendarios menstruales o calculadoras de embarazo } \\
\text { desde el punto de vista técnico. }\end{array}$ \\
\hline $\begin{array}{l}\text { Control sobre } \\
\text { la interfaz } \\
\text { gráfica }\end{array}$ & $\begin{array}{l}\text { Que la aplicación sea de fácil comprensión y que tenga características } \\
\text { anatómicas deseables en términos estéticos, lingǘ́sticos, enlaces de } \\
\text { ayuda y de vocabulario, más aún cuando se trata de calendarios o } \\
\text { calculadoras que tengan varios portales o funciones. }\end{array}$ \\
\hline $\begin{array}{l}\text { Control sobre } \\
\text { usabilidad }\end{array}$ & $\begin{array}{l}\text { Garantía de que la app cumpla con atributos de efectividad, facilidad } \\
\text { de aprendizaje, memorabilidad, seguridad, portabilidad, contenido } \\
\text { guiado e instrucciones, que le permitan a la usuaria autogestionar su } \\
\text { condición sexual y reproductiva. }\end{array}$ \\
\hline $\begin{array}{l}\text { Control sobre } \\
\text { seguridad de la } \\
\text { información }\end{array}$ & $\begin{array}{l}\text { Que exista un conjunto de medidas preventivas y reactivas, para } \\
\text { proteger los datos personales sensibles. En el ámbito ginecobstétrico, } \\
\text { que exista consentimiento previo, expreso e informado, así como } \\
\text { información de la destinación de los datos personales sensibles. }\end{array}$ \\
\hline $\begin{array}{l}\text { Análisis de } \\
\text { parámetros } \\
\text { clínicos }\end{array}$ & $\begin{array}{l}\text { Pruebas piloto, ensayos clínicos o evaluaciones preclínicas que } \\
\text { permitan evaluar la eficacia del calendario menstrual o calculadora de } \\
\text { embarazo, así como evaluar en qué condiciones el uso de la aplicación } \\
\text { es contraindicado. }\end{array}$ \\
\hline médica & $\begin{array}{l}\text { Evaluación y análisis sobre los datos clínicos tomados por un } \\
\text { dispositivo médico tienen el valor matemático y clínico para dar un } \\
\text { resultado certero, seguro y eficaz que no ponga en riesgo la salud de } \\
\text { la paciente. }\end{array}$ \\
\hline
\end{tabular}

Fuente: Ramírez, Guillén y Cifuentes (2016).

Consideramos que los factores mencionados son los elementos clave que debe adoptar el Estado colombiano para cumplir con un doble enfoque fundado en el riesgo a la salud y la protección de los datos personales. Es innegable que un Estado que no incluya en su agenda el tema de la telesalud demuestra una falta de compromiso con el bienestar y la salud. El nuevo milenio nos plantea nuevos retos, y una medicina que no acoja los avances tecnológicos es una medicina 
anacrónica, pero una medicina que no acoja los parámetros de la responsabilidad es una medicina injusta.

\section{Referencias}

Alonso-Arévalo, J. y Mirón-Canelo, J. (2017) Aplicaciones móviles en salud: potencial, normativa de seguridad y regulación. Revista Cubana de Información en Ciencias de la Salud 28(3). Recuperado de http://www.rcics.sld.cu/ index.php/acimed/article/view/1136/690

Carnicero,J.y Fernández,A.(Coords.).(2011). Manual de salud electrónica para directivos de servicios y sistemas de salud. Santiago de Chile: Naciones Unidas. Recuperado de https:// repositorio.cepal.org/bitstream/handle/11362/3023/1/ S2012060_es.pdf

Comisión Europea. (2014). Libro verde sobre sanidad móvil. Bruselas: Autor. Recuperado de https://ec.europa.eu/ transparency/regdoc/rep/1/2014/ES/1-2014-219-ESF1-1.Pdf

Correa Díaz, A. M. (2017). Avances y barreras de la telemedicina en Colombia. Revista de la Facultad de Derecho y Ciencias Politicas, 47(127), 363-384. Recuperado de http://www.scielo.org.co/pdf/rfdcp/v47n127/0120-3886rfdcp-47-127-361.pdf

Cortez, N. G., Cohen, I. G. y Kesselheim, A. S. (2014). fdA regulation of mobile health technologies. New Englang Journal of Medicine 371(4), 372-379.

Eysenback, G. (2001). What is e-health. Journal of Medical Internet Research,3(2).https://doi.org/10.2196/jmir.3.2.e20

Food and Drug Administration (FDA). (2013). Mobile medical applications: Guidance for industry and Food and Drug Administration staff. s. 1.: Autor. 
Food and Drug Administration (FDA). (2018, 10 de agosto). FDA allows of first direct to consumer app for contraceptive use to prevent pregnancy. Recuperado de https://www. fda.gov/news-events/press-announcements/fda-allowsmarketing-first-direct-consumer-app-contraceptive-useprevent-pregnancy

Gonzales F. (2012). La bistoria clinica electrónica. Recuperado de https://repositorio.cepal.org/bitstream/handle/11362/3023/S2012060_es.pdf?sequence $=1$

Gutiérrez, A. (2003). Alfabetización digital: Algo más que ratones y teclas. Barcelona: Gedisa.

Invima. (2012). Programa Nacional de Tecnovigilancia. Recuperado de https://www.invima.gov.co/programa-nacionalde-tecnovigilancia

Jiménez Barbosa, W. G. y Acuña Gómez J. S. (2015). Avances en telesalud y telemedicina: Estrategia para acercar los servicios de salud a los usuarios. Acta Odontológica Colombiana 5(1), 101-115. Recuperado de https://revistas. unal.edu.co/index.php/actaodontocol/article/view/52283

Mugaraza F. (2014). Prólogo. En The App Intelligence, Informe 50 mejores apps de salud en español. Observatorio Zeltia, The App Date, Catedra ISC, Red de Innovación, Wawe App Health. Recuperado de https://es.slideshare.net/ joseavil/informe-tad50mejoresappsdesalud

Nader, K. Ch. (2018, 30 de abril). La importancia de la telemedicina en la tele-ginecobstetricia. El Hospital [blog]. Recuperado de http://www.elhospital.com/blogs/Laimportancia-de-la-telemedicina-en-la-Tele-ginecoobstetricia+125376

Organización Mundial de la Salud (oms). (2012, 17 de octubre). La UIT y la OMS lanzan la Iniciativa salud móvil para 
luchar contra las enfermedades no transmisibles. Recuperado de https://www.who.int/mediacentre/news/releases/2012/ mHealth_20121017/es/

Organización Mundial de la Salud (oms).(2019,19 de septiembre). Reducir la mortalidad de los recién nacidos. Recuperado de https://www.who.int/es/news-room/fact-sheets/detail/ newborns-reducing-mortality

Organización Panamericana de la Salud y Organización Mundial de la Salud. (2011, 1 de agosto). Estrategia y plan de acción sobre eSalud (2012-2017). Recuperado de https:// www.paho.org/hq/dmdocuments/2011/CD51-13-s.pdf Prystowsky, N. y Walland, J. (2018). Emerging issues in using mobile apps for clinical research. NYSBA Health Law Journal, 23(3), 56-62. Recuperado de https://www.nysba.org/ DownloadAsset. aspx?id=90620

Ramírez, L., Guillén, E. y Cifuentes, Y. (2016). Estrategia de validación para aplicaciones móviles de salud. Actas de Ingeniería, 2, 325-333.

Reig, J. (2002). Historia de salud electrónica: ¿Cambiando las reglas del juego? Todo Hospital (191), 700-709.

Sánchez García,J. M. (2017, 15 de junio). App de salud: Dos modelos pioneros en España para acreditar su calidad y seguridad. Think Big [blog]. Recuperado de https://empresas.blogthinkbig.com/app-de-salud-dos-modelos-pioneros-en-espana-para-acreditar-su-calidad-y-seguridad/ Santamaría-Puerto, G. A.y Hernández-Rincón, E.H.(2015). Aplicaciones médicas móviles: Definiciones, beneficios y riegos. Revista Cientifica Salud Uninorte 31(3). Recuperado de http://rcientificas.uninorte.edu.co/index.php/ salud/article/view/7622 
Santillán García, A. y Martínez Casas, J. M. (2015). Apps de salud: Nuevas herramientas para el cuidado del paciente cardiológico. Enfermería en Cardiología 22(66), 28-34. Recuperado de https://www.enfermeriaencardiologia. com/wp-content/uploads/66_03.pdf

Shea, M. J. (2017). Electrocardiografía. En Manual MSD. Recuperado de https://www.msdmanuals.com/es-co/ hogar/trastornos-del-coraz\%C3\%B3n-y-los-vasossangu\%C3\%ADneos/diagn\%C3\%B3stico-de-las-enfermedades-cardiovasculares/electrocardiograf $\% \mathrm{C} 3 \% \mathrm{ADa}$ Trevignani, M. (2014). La salud móvil: Un estudio de multidimensionalidad de aplicaciones móviles (tesis de maestría), Universidad de Alicante, España.

Vega, R. F. (2018). mHealth: El uso de aplicaciones móviles en medicina.AnestesiaR, 10(9), 6. https://doi.org/10.30445/ rear.v10i9.652 


\title{
Exigibilidad del derecho a la participación de las mujeres campesinas de Cerrito (Santander) en la delimitación del páramo del Almorzadero: estudio de caso ${ }^{*}$
}

\author{
Angie Carolina Herrera Ramírez \\ María Victoria Jaimes Becerra \\ Carolina Isabel Montes Perea \\ Ivone Alejandra Prada Torres
}

* Este documento es producto del trabajo del Semillero Vida, Ciencia y Derechos Humanos de la Escuela de Derecho y Ciencia Política de la Universidad Industrial de Santander, coordinado por el docente Cristian Hernán Gómez Navarro.

** Estudiante de X semestre de Derecho. Miembro activo del Semillero Vida, Ciencia y Derechos Humanos de la Escuela de Derecho y Ciencia Política de la Universidad Industrial de Santander. Correo electrónico: ancahera28@gmail.com

*** Estudiante de X semestre de Derecho. Miembro activo del Semillero Vida, Ciencia y Derechos Humanos de la Escuela de Derecho y Ciencia Política de la Universidad Industrial de Santander. Correo electrónico: vimajabe@gmail.com

***** Estudiante de VI semestre de Derecho. Estudiante de II semestre de la Maestría en Derechos Humanos. Miembro activo del Semillero Vida, Ciencia y Derechos Humanos de la Escuela de Derecho y Ciencia Política de la Universidad Industrial de Santander. Correo electrónico: carolinamontesperea@gmail.com

****** Estudiante de X semestre de Derecho. Miembro activo del Semillero Vida, Ciencia y Derechos Humanos de la Escuela de Derecho y Ciencia Política de la Universidad Industrial de Santander. Correo electrónico: ivonprada.ip@gmail.com 
Resumen: En este capítulo se presentan avances del acompañamiento realizado por el Semillero Vida, Ciencia y Derechos Humanos a la Asociación de Mujeres Campesinas y Artesanas de Cerrito, con el objetivo de construir una acción jurídica garante del derecho a la participación en la toma de decisiones ambientales de las mujeres cerritanas, vulnerado mediante la Resolución 152 de 2018 del Ministerio de Ambiente y Desarrollo Sostenible, que delimitó el páramo del Almorzadero. Se demuestra que el ministerio no aplicó el precedente establecido en la sentencia T-361/2017, frente al derecho a la participación de las comunidades en los procesos de delimitación de páramos y el derecho de las mujeres a participar en la toma de decisiones ambientales, entendido desde el bloque de constitucionalidad y como meta del quinto Objetivo de Desarrollo Sostenible de la Organización de las Naciones Unidas. Para ello se recurrió a la metodología cualitativa del estudio de caso; los datos obtenidos a partir del trabajo de campo se confrontaron con los fundamentos jurídicos aplicables, cuyos resultados motivaron la presentación de una acción de tutela, que a la fecha se encuentra decidiendo en segunda instancia por el Tribunal Superior del Distrito Judicial de Bucaramanga.

Palabras clave: delimitación de páramos, derecho a la participación, mujeres campesinas, igualdad de género.

\section{Introducción}

En un escenario de delimitaciones exprés de páramos, que se ha dado a lo largo del territorio nacional, en perjuicio de los derechos fundamentales de las comunidades afectadas 
por estas decisiones y que está siendo objeto de debate en la jurisdicción constitucional, en el presente capítulo se expone la sistematización de los avances que se han tenido en el marco del acompañamiento que el Semillero Vida, Ciencia y Derechos Humanos ha realizado a las mujeres de la Asociación de Mujeres Campesinas y Artesanas de Cerrito (Asomuarce) frente a esta discusión sociojurídica sobre la delimitación del páramo del Almorzadero.

Este acompañamiento surge a partir de las inquietudes planteadas por parte de las directivas de Asomuarce al equipo del semillero, una vez fue establecida la delimitación en la Resolución 152 de 2018, expedida por el Ministerio de Ambiente y Desarrollo Sostenible (MADs), a saber:

- Si ellas, como mujeres, tenían derecho a ser consultadas o a participar en el proceso de delimitación del páramo del Almorzadero adelantado por el MADs.

- Las acciones legales que debería desplegar el MADS para permitir o facilitar la participación de las comunidades y, en especial, de las mujeres en la fijación de los límites del páramo.

- Las acciones jurídicas que se podrían emprender para proteger sus derechos como mujeres frente a la decisión de delimitación del páramo.

En ese orden de ideas, como parte de un ejercicio tanto de clínica jurídica como investigativo, a través de la metodología cualitativa (Quecedo y Castaño, 2002), particularmente del estudio de caso (Martínez Carazo, 2006), el semillero procedió a acercarse al tema, bajo las siguientes consideraciones: 1) el estudio de caso permitiría abordar una situación real, no 
simulada o hipotética; 2) se trata de una asociación que no contaba con apoyo jurídico para resolver la problemática en cuestión; 3) posibilitaría definir unos conceptos jurídicos para confrontarlos con una realidad concreta, y 4) desarrollaría un espacio para la interposición de una acción jurídica con resultados concretos sobre el problema abordado.

Al tratarse de un estudio de caso, la estrategia de acercamiento principal fue de carácter empírico, y con este enfoque se abordaron las consideraciones 1 y 2: la caracterización de la situación. Esta se estableció a partir de la contextualización del problema, que incluyó el acompañamiento a un sujeto de especial protección. En consecuencia, se tomaron en cuenta aspectos como la zona geográfica donde se situaba el problema, las causas del problema, la tensión entre la protección de los ecosistemas y las necesidades y visiones de las comunidades, los efectos de la delimitación en la vida de las mujeres de la zona y la forma como el MADs socializó el proceso de delimitación y verificó la participación de la comunidad.

Posterior a esta caracterización, el semillero confrontó la situación con fundamentos jurídicos tratados por la jurisprudencia constitucional, para desarrollar la tercera consideración. Los conceptos analizados por el semillero fueron el derecho a la participación en decisiones ambientales y la participación de la mujer en la toma decisiones ambientales. El primer concepto se analizó desde la perspectiva dispuesta por la Corte Constitucional en la sentencia T-361 de 2017 y las subreglas allí establecidas. Entre tanto, el segundo concepto se desarrolló a partir del principio 20 de la Declaración de Río sobre el Medio Ambiente y el Desarrollo (Organización de las Naciones Unidas [oNU], 1992). 
Una vez analizados los conceptos jurídicos y confrontados sus contenidos con la caracterización, analizamos la viabilidad de una acción jurídica, cumpliendo la consideración 4, con el fin de proteger los derechos de las mujeres del municipio del Cerrito a la participación en el proceso de delimitación del páramo del Almorzadero. Concluimos que la acción más pertinente era la acción de tutela, debido a la naturaleza del conflicto: la vulneración de derechos fundamentales de un sujeto de especial protección y a que sus resultados pueden llevar a garantizarlos efectivamente. En ese sentido, elaboramos una demanda de tutela que se presentó a nombre de la Asociación y sus miembros, que a la fecha conoce el Tribunal Superior del Distrito Judicial de Bucaramanga, en sede de impugnación. Por lo tanto, una vez se tenga el fallo, se entra a analizar la decisión, la calidad argumentativa, el seguimiento de los precedentes, el efecto en la comunidad y la posibilidad de acudir en sede de revisión a la Corte Constitucional.

Para la realización de este proyecto, contamos con la participación directa de Asomuarce, principalmente de su junta directiva y lideresas, quienes en asamblea general de asociadas autorizaron de manera unánime el acompañamiento del semillero y la eventual interposición de acciones legales. El trabajo realizado con ellas fue oral y, posteriormente, se registró en relatorías y fotografías. Asimismo, acudimos, vía derecho de petición, a los documentos que sirvieron de respaldo para la expedición de la Resolución 152 de 2018 del MADS, entre ellos los estudios de delimitación y las actas, relatorías, informes e imágenes con los cuales el MADs pretendía probar la efectiva participación de las comunidades parameras en el proceso de delimitación. Esta información 
obtenida de las distintas fuentes y perteneciente a realidades distintas (material y jurídica), se contrastó posteriormente con las reglas constitucionales sobre el derecho a la participación ambiental, a fin de determinar la procedibilidad de una acción de tutela.

Como se ha expresado, el documento es un avance de un proceso de acompañamiento más amplio que busca proteger el derecho a la participación de las mujeres en la toma de decisiones ambientales, especialmente aquellas relacionadas con la protección de ecosistemas estratégicos. La propuesta se inscribe en este evento, por cuanto el conflicto aquí evidenciado se enmarca en uno de los Objetivos de Desarrollo Sostenible: "igualdad de género", que apunta a la consecución de la meta de asegurar la participación plena y efectiva de las mujeres y la igualdad de oportunidades de liderazgo en todos los ámbitos decisorios en la vida política, económica y pública. A través de la acción jurídica y el acompañamiento se busca más que suspender el proceso de delimitación, garantizar la participación real y efectiva de las mujeres de la comunidad del municipio del Cerrito y de las demás mujeres del área de influencia del páramo, en el proceso de protección y defensa, a efectos de posibilitar la apertura de escenarios de diálogo y construcción de consensos entre ellas y la institucionalidad, para la incorporación de criterios de género en las políticas de protección del ecosistema paramuno y facilitar la resolución de conflictos por las tensiones que se generan con las comunidades involucradas.

\section{Planteamiento del problema}

En las últimas décadas, el discurso de la protección del medio ambiente desde diferentes sectores políticos, económicos y 
sociales ha sido una constante. La explotación indiscriminada de los recursos y la contaminación producida por el ser humano han generado un sinnúmero de catástrofes ambientales con daños irreversibles que inciden de forma negativa en la calidad de vida de quienes habitan en las zonas afectadas. Así, en distintos lugares del mundo se han alzado voces para reclamar a los gobiernos y a los altos mandos políticos la toma de medidas efectivas para contrarrestar el cambio climático y preservar el medio ambiente, dada su relación con el ejercicio de los derechos fundamentales como la vida y la salud. Por ello, diferentes Estados han decidido sumarse a la protección del medio ambiente desde el derecho y sus instituciones, mediante la inclusión de derechos ambientales dentro de sus constituciones o de su adherencia a tratados o convenios internacionales que garantizan la protección del medio ambiente desde el derecho internacional. En este orden de ideas, ha mencionado el relator especial de la ONU sobre los derechos humanos y el medio ambiente lo siguiente:

Aunque el derecho a un medio ambiente saludable aún no ha sido reconocido a nivel global en un tratado de derechos humanos de las Naciones Unidas, los organismos de derechos humanos han reconocido que una amplia gama de otros derechos, como los derechos a la vida, la salud, la alimentación y el agua, dependen para su pleno goce, de un medio ambiente sano. Los individuos han alegado violaciones a estos derechos como consecuencia de la contaminación y otros tipos de daños al medio ambiente, y los tribunales internacionales y nacionales han respondido mediante la creación de una nueva jurisprudencia de derechos humanos del medio ambiente. (Knox, 2016, p.3) 
Ahora, si nos situamos en Colombia, país reconocido internacionalmente por su riqueza en términos de biodiversidad, se observa que los ecosistemas que la componen son variados. En efecto, parte de la riqueza ambiental colombiana está constituida por los páramos; según expertos, Colombia cuenta con el mayor porcentaje de páramos del mundo:

Los ecosistemas de páramo en Colombia presentan una extensión aproximada de 1.925.410 hectáreas de las cuales 746.644 se encuentran en áreas de Parques Nacionales Naturales. A pesar de que esta área corresponde solo al $2 \%$ del territorio nacional, nos destacamos a nivel mundial como el país con la mayor área de estos ecosistemas. (Ospina y Rodríguez, 2011, p. 9)

La importancia de estos territorios y los beneficios que otorgan a las comunidades que dependen de ellos y de los ecosistemas que allí se desarrollan son de suprema relevancia. Según Ospina y Rodríguez:

Además de su alta diversidad de especies y hábitats, los páramos prestan importantes servicios ecosistémicos que son fundamentales para el bienestar de todos los colombianos. En este sentido, los páramos son pieza clave en la regulación del ciclo hídrico (en estos ecosistemas nacen las principales estrellas fluviales del país, las cuales abastecen de agua a más del 70\% de los colombianos), almacenan y capturan gas carbónico de la atmósfera, contribuyen en la regulación del clima regional, son hábitat de especies polinizadoras y dispersoras de semillas y son sitios 
sagrados para la mayoría de culturas ancestrales, entre muchos otros beneficios. (2011, p. 9)

Y así como otros ecosistemas de nuestro territorio se han visto afectados por actividades hechas por el ser humano que vulneran el derecho a un ambiente sano, las actividades que principalmente afectan los páramos suelen estar relacionadas con la extracción minera, la sobreexplotación agrícola, el poblamiento del territorio, entre otras (Instituto de Investigación de Recursos Biológicos Alexander von Humboldt, 2011). En ese sentido, y en cumplimiento de obligaciones internacionales, el Estado colombiano se dio a la tarea de delimitar los páramos.

Los procesos de delimitación resultan en diversas ocasiones muy complejos, pues, aunque el Instituto von Humboldt ha establecido ciertos criterios (Ospina y Rodríguez, 2011), cada caso en concreto presenta particularidades y no siempre las comunidades dependientes de los páramos resultan satisfechas con las delimitaciones, máxime si no fueron parte activa del proceso. Resulta pertinente traer a colación los casos de las delimitaciones del páramo de Santurbán y del páramo de Pisba. Frente a ambos casos, se decidió, en sede de tutela, que se habían vulnerado los derechos a la participación ambiental de los accionantes, debido a que estos y las comunidades de las áreas de influencia de los páramos no habían sido partícipes del proceso delimitatorio. Tales situaciones demuestran que el Gobierno colombiano, en su afán de delimitar los páramos, ha pasado por encima de principios fundantes de nuestro ordenamiento jurídico, entre otros, el principio democrático. Sin embargo, estos no son 
los únicos casos. Un ejemplo de lo anterior es la delimitación del páramo del Almorzadero establecida en la Resolución 152 de 2018, expedida por el MADs.

\section{Ubicación geográfica}

El páramo del Almorzadero se ubica en la cordillera Oriental de los Andes colombianos al noreste del departamento de Santander y al suroeste de Norte de Santander. Este ecosistema es de vital importancia, por cuanto habitan diversas especies de plantas y animales y presta diversos servicios ecosistémicos, como aprovisionamiento de alimentos, de recursos genéticos e hídricos, servicios culturales, ecoturísticos, entre otros. Diecisiete municipios tienen jurisdicción sobre el área del páramo, entre ellos el de Cerrito. Este se encuentra ubicado en la parte oriental del departamento de Santander, a 188 kilómetros de Bucaramanga, a 2500 ms.n.m. y situado en lo que se conoce como la provincia de García Rovira. Su población total es de 6230 habitantes, de los cuales el $51,7 \%$ son hombres y el $48,3 \%$ son mujeres (Plan de Desarrollo 2016-2019, 2019).

\section{Causas de la problemática}

La delimitación y las mujeres cerritanas: protección

del ecosistema, necesidades y visiones de las mujeres

"La delimitación del Páramo del Almorzadero no contó con un proceso de participación de las mujeres habitantes del Páramo" (Taller Asomuarce, 20 de mayo de 2018). Esta afirmación es realizada por la asociación que reúne a más de 200 mujeres del municipio de Cerrito, tanto del sector urbano como del rural. 
Ante las manifestaciones sobre la vulneración del derecho a la participación de las mujeres cerritanas durante el proceso de delimitación, el 20 de mayo de 2018, el semillero realizó un taller con 200 asociadas de Asomuarce, habitantes del casco urbano y de las veredas del municipio. Fue desarrollado en una sola jornada de aproximadamente cinco horas, en la que las mujeres tuvieron la palabra. Esta actividad se realizó, en términos metodológicos, bajo los parámetros de la técnica de grupos focales, mediante la cual se pretendía tener mayor interacción con el grupo y obtener diversas percepciones y reacciones frente al tema que las convocaba (Escobar y Bonilla-Jiménez, 2009).

La primera parte del taller consistió en determinar cómo se entienden las mujeres con respecto al páramo, es decir, cómo entienden al ecosistema y qué implicaciones ha tenido la delimitación de este en sus vidas. Se consideró pertinente abordar esta primera parte, pues, de conformidad con el Instituto Alexander von Humboldt (2011), los páramos, más allá de ser ecosistemas de suma importancia para la regulación del agua, la retención de carbono y la conservación de distintas especies animales y vegetales, en su mayoría endémicas, son el territorio de comunidades campesinas y aborígenes, al cual deben, en parte, sus formas de vida e interacción (por ejemplo, su identidad). Se calcula que han sido poblados desde hace, al menos, diez mil años. Es decir, los páramos son socioecosistemas en los cuales son tan importantes las comunidades que los habitan como los servicios ecosistémicos que estos prestan.

Para ello, se organizaron seis grupos de discusión en los que las mujeres respondieron a las preguntas formuladas por 
el semillero en relación con la vivencia de cada una, de sus familias y de la Asociación con el páramo; los cambios en el paisaje y las causas de la transformación; al igual que las percepciones e implicaciones de la delimitación del páramo en sus vidas. Las respuestas fueron escritas en carteles que luego fueron socializados en plenaria, con el fin de concluir de manera conjunta cuál era su papel como mujeres campesinas en el páramo y si era importante o no la delimitación realizada por el Estado.

A partir de las conclusiones obtenidas en la plenaria, se discutió el proceso de delimitación y su participación como asociación de mujeres. Con esta etapa se determinó si efectivamente ellas se sintieron parte del proceso, si fueron escuchadas y si sus propuestas tuvieron algún eco. Asimismo, se buscó conocer un poco del proceso y la participación de los habitantes del municipio, principalmente de las mujeres. Después se hizo una breve exposición del caso Santurbán, tema que se desarrolla posteriormente, y de la sentencia de tutela que ordenó se realizara de nuevo el proceso de delimitación (Sentencia T-361 de 2017). Se les informó a las asistentes cuáles eran los derechos que tenían las comunidades parameras en los procesos de delimitación y luego se dio la palabra a las que quisieran participar para que contaran su experiencia frente a este proceso. Dentro de la síntesis de las conclusiones, podemos resaltar las siguientes:

Frente al significado del páramo en relación con sus vivencias como mujeres campesinas:

Como colectividad de mujeres campesinas, concluimos que el páramo es nuestro sustento, el de nuestras familias y el del pueblo; es nuestro hogar; el futuro de nuestros 
hijos; es agua, aire limpio, riqueza, patrimonio; es fuente de vida y de empleo; es un lugar donde hay estabilidad emocional, paz y tranquilidad. El páramo para nosotras es agricultura. En este lugar nos sentimos libres, nos sentimos bien, pues estamos orgullosas de vivir en el campo. Por ello es que estamos preocupadas por esta delimitación. (Taller Asomuarce, 20 de mayo de 2018)

Percepciones e implicaciones de la delimitación:

Esta delimitación en la que no fue tenida en cuenta nuestra voz, que debería ser una decisión basada, más allá de meros criterios técnicos, en aspectos políticos y ajustada a las dinámicas propias del socioecosistema paramuno de Almorzadero, presenta serias dificultades que hemos identificado: i) Problemas actuales: Algunas de nosotras nos hemos tenido que enfrentar a las negativas de las entidades financieras a solicitudes de crédito, pues, como nuestros predios están ubicados entre 2800 y 3000 metros sobre el nivel del mar, allí ya no se puede hacer nada. Cultivar se está volviendo algo más difícil de lo que ya era. Esta situación va a conducirnos a abandonar los predios. ii) Eventuales problemas: Como se terminará el sustento de nuestras familias tradicionalmente campesinas, es lógico que muchos tendremos que desplazarnos en contra de nuestro querer, incluso algunos se dedicarán a la criminalidad ante la falta de posibilidades y al incremento de la pobreza. Es claro que habrá escasez de alimentos, lo cual será un problema que trascienda a nuestro pueblo. Nuestra calidad de vida evidentemente va a disminuir. (Taller Asomuarce, 20 de mayo de 2018) 
Después de las intervenciones, las asociadas llegaron a las siguientes conclusiones:

La delimitación, que no nos ha beneficiado en absolutamente nada, reduce nuestro espacio para subsistir; el Gobierno, en vez de capacitarnos para cuidar adecuadamente nuestro territorio, está tomando decisiones que desmejoran nuestra vida campesina y nos arrojan a la incertidumbre sin tenernos en cuenta. A las mujeres no nos tuvieron en cuenta porque, empezando que la mayoría de las fincas no están tituladas, quienes tradicionalmente han sido titulares de las pocas que sí, son los hombres. Esto nos ha desconocido como mujeres, como sujetos válidos con preocupaciones propias, ha hecho que nos mantengamos invisibilizadas. Es por eso que hoy por hoy no tenemos información suficiente sobre la delimitación del páramo y lo único que sentimos además de preocupación e inconformidad es incertidumbre y zozobra.

El Gobierno nos avisó cuando ya había delimitación, cuando como cerritanas no podíamos hacer nada. A pesar de que desde Bogotá digan que hubo participación de la comunidad, es preciso manifestar que en varias ocasiones se nos hizo firmar algunos documentos sin ser informadas de la razón de ser de los mismos, sin nuestro consentimiento informado. Muchas veces nos pidieron que se firmara la asistencia a ciertas reuniones, pero ello no significa que hayamos aceptado lo que en esas reuniones lo que expuso el Gobierno. Porque en Bogotá tracen una raya no va a arreglarse el problema con el medio ambiente. (Taller Asomuarce, 20 de mayo de 2018) 
La participación de la comunidad para el Ministerio de Ambiente y Desarrollo Sostenible

Con el fin de contrastar la información que fue proporcionada por las mujeres en el taller, se solicitaron al MADs todos los soportes del proceso de delimitación, vía derecho de petición, así: que informaran acerca del procedimiento de participación de la comunidad en la delimitación del páramo del Almorzadero, de los estudios previos realizados para la delimitación y la resolución a través de la cual se delimitó el páramo y los respectivos soportes. Esta petición no fue contestada en término y se presentó una acción de tutela en la que se solicitó se protegieran los derechos fundamentales a hacer peticiones respetuosas y obtener respuesta, al acceso a la información y a la libertad de expresión, derechos vulnerados por la actuación omisiva del MADs. Fue durante el trámite de la acción de tutela que el MADs respondió el derecho de petición y se procedió a negar el amparo por hecho superado.

La respuesta del mads, recibida el 22 de junio de 2018, señaló las actividades desarrolladas con la comunidad del páramo, que tuvieron lugar entre abril y agosto de 2017, tanto en los diferentes municipios que conforman el páramo del Almorzadero como en la capital del país. Se resalta que el ministerio indicó que en algunas de las reuniones se recogieron propuestas de los campesinos y se brindó información sobre el proceso de delimitación; sin embargo, no hay sustento respecto a si esas inquietudes fueron atendidas dentro del acto administrativo expedido.

Referente a la solicitud de informar cuáles fueron los estudios previos utilizados para la delimitación del páramo, señalaron que se analizaron estudios técnicos, sociales, 
económicos y ambientales elaborados por la Corporación Autónoma Regional para la Defensa de la Meseta de Bucaramanga, la Corporación Autónoma Regional de la Frontera Nororiental, la Corporación Autónoma de Santander y el escritorio de recomendaciones del Instituto de Investigación de Recursos Biológicos Alexander von Humboldt. Finalmente, remitieron la resolución a través de la cual se delimitó el páramo del Almorzadero (MADs, 2018).

Posterior a la entrega de esta respuesta, se recibió un nuevo correo electrónico de parte del MADs, en el cual se señalaron algunas fechas de actividades y se anexaron algunos listados de asistencia y actas, de los cuales gran parte hace referencia a la comunidad indígena u'wa. El 9 de julio se consideró necesario presentar otro derecho de petición (rad. E1-2018-019645) solicitando los soportes precisos de cada una de las actividades realizadas dentro del proceso de participación de la delimitación del páramo del Almorzadero. Dicho derecho de petición fue contestado el 1 de agosto de 2018; allí se hicieron unos ajustes correspondientes a fechas y municipios que se habían relacionado en la anterior respuesta del MADs. En el documento anexo, denominado Relatoría Pamplona, se evidenciaron una serie de comentarios y preocupaciones de parte de habitantes de Cerrito, pero no se observaron las respuestas a dichas inquietudes, ni los compromisos adquiridos por las partes.

De esa forma, no existen soportes de participación de la comunidad, lo que prueba que los espacios organizados durante el proceso de delimitación del páramo del Almorzadero fueron destinados a actividades de información y socialización, pero no de participación y concertación. Por ello, las medidas adoptadas desconocieron las características 
y las necesidades propias de la comunidad involucrada. Entre los documentos remitidos por el maDs se encuentran los estudios de las corporaciones regionales que sirvieron de base para expedir la Resolución. A partir de su análisis se llegó a las siguientes conclusiones: 1) los estudios socioeconómicos que sirvieron de base para la expedición de la Resolución 152 de 2018 por parte del MADs no se hicieron con una metodología que garantizara o permitiera la participación de las mujeres de la región. 2) E1 documento denominado Complejo páramo Almorzadero Santander, presentado por la Corporación Autónoma de Santander, contiene un capítulo denominado "Caracterización sociocultural y económica". Sin embargo, tal caracterización no contó con una metodología participativa y se realizó con fuentes secundarias, como estudios del Departamento Administrativo Nacional de Estadística con proyección a 2013, a partir del censo elaborado por esta institución en 2005; además, señalan la elaboración de una encuesta que no expone ficha técnica. 3) Asimismo, las actividades económicas de los pobladores se establecieron con base en los esquemas de ordenamiento territorial que realizaron los municipios, los cuales el mismo documento reconoce que son antiguos, de hace quince años.

Satisfechas las peticiones de información y solicitudes de documentos, se procedió a analizar los documentos proporcionados a la luz de las exigencias de la sentencia T-361 de 2017 y del bloque de constitucionalidad en materia de derechos de las mujeres campesinas.

\section{Objetivos}

Ante este escenario nos planteamos los siguientes objetivos: 


\section{Objetivo general}

Brindar a Asomuarce herramientas jurídicas para la defensa de su derecho, y el de sus asociadas, a la participación en la toma de decisiones ambientales, frente al proceso de delimitación del páramo del Almorzadero.

\section{Objetivos especificos}

- Determinar si hubo desconocimiento del precedente constitucional en materia de participación ambiental en el proceso de delimitación del páramo del Almorzadero, en particular frente a la participación de las mujeres campesinas.

- Proponer soluciones jurídicas a la vulneración de derechos de Asomuarce y sus asociadas, frente a la delimitación del páramo del Almorzadero.

- Contribuir a la generación de espacios de participación para las mujeres cerritranas en el proceso de delimitación del páramo del Almorzadero y los que guarden relación con él, desde un enfoque diferencial.

- Posicionar a las mujeres cerritanas y a Asomuarce frente al Gobierno nacional y al Estado colombiano como interlocutoras válidas en la defensa del territorio, el medio ambiente y los derechos de las mujeres campesinas.

\section{Hipótesis}

Una vez analizada la información proporcionada por la comunidad y por el MADS, se formuló la siguiente hipótesis: las mujeres cerritanas de Asomuarce no fueron partícipes del proceso de delimitación del páramo del Almorzadero, ni en su dimensión individual ni como colectivo, lo cual 
configura 1) una vulneración del derecho fundamental a la participación en la toma de decisiones ambientales y 2) un desconocimiento a sus derechos como mujeres campesinas.

\section{Fundamentación jurídica}

Caracterizada la situación, se verificó cómo enmarcarla dentro de conceptos jurídicos que permitieran su encausamiento hacia una acción de protección de sus derechos. Teniendo en cuenta que se conocía la decisión de la Corte Constitucional adoptada en la sentencia T-361 de 2017, que dejó sin efecto el acto administrativo que delimitó el páramo de Santurbán, se abordó el estudio del fallo para verificar si se podía usar en este caso como precedente aplicable en los términos de la sentencia T-292 de 2006 de la misma corporación. Asimismo, se indagó si existe una norma o una regla jurídica que proteja el derecho a la participación ambiental de las mujeres, y se encontró el principio 20, de la Declaración de Río sobre el Medio Ambiente y el Desarrollo, que establece: "Las mujeres desempeñan un papel fundamental en la ordenación del medio ambiente y en el desarrollo. Es, por tanto, imprescindible contar con su plena participación para lograr el desarrollo sustentable" (Organización de las Naciones Unidas, 1992). A partir de estos dos instrumentos jurídicos - la sentencia de la Corte y el principio de la declaración- se procedió a verificar su contenido y la posibilidad de materializarlo en una acción jurídica.

\section{El derecho a la participación ambiental}

La sentencia T-361 de 2017 dejó sin efecto el acto administrativo a través del cual el MADs delimitó el páramo de Santurbán. Esta decisión es consecuencia de varios derechos 
fundamentales que la Corte consideró vulnerados por parte del ministerio. Uno de esos derechos lo llamó derecho a la participación ambiental. La Corte, en la sentencia, construye una argumentación dedicada a plantear cómo en un Estado social de derecho la democracia es un valor fundamental por proteger y garantizar. Para ello afirma que el modelo adoptado por la Constitución de 1991 es la democracia participativa en la que el ciudadano está llamado a tomar parte en los procesos de toma de decisiones públicas, para lo cual deben existir mecanismos que permitan hacer efectiva la expresión ciudadana (sentencia T-066 de 2015); que este carácter democrático implica un mandato de consulta a los afectados por parte de las autoridades (sentencia C-150 de 2015), y que el modelo participativo va más allá de la elección de representantes, pues implica la existencia de un derecho fundamental a participar activamente en la toma de decisiones colectivas (sentencia C-179 de 2002).

Desde estos criterios jurisprudenciales, la Corte procedió a determinar el derecho fundamental de participación ambiental a partir de la impronta ecológica de la Constitución de 1991 (sentencia C-499 de 2015), estableciendo el marco jurídico que garantiza este derecho. Para la construcción del marco jurídico se apoyó en los artículos 2 y 79 constitucionales y las normas internacionales que en materia ambiental deben tenerse en cuenta para garantizar la participación de acuerdo con su nivel de obligatoriedad. Sobre esto último indicó que existen tres niveles (tabla 1). 
Tabla 1. Niveles de participación

\begin{tabular}{|l|l|}
\hline \multicolumn{1}{|c|}{ Nivel } & \multicolumn{1}{c|}{ Grupo normativo } \\
\hline $\begin{array}{l}\text { 1) La utilización forzosa de los } \\
\text { tratados firmados por Colombia } \\
\text { en virtud del artículo 93 de la } \\
\text { Constitución. }\end{array}$ & $\begin{array}{l}\text { Artículo 4 del Protocolo de San Salvador. } \\
\text { Artículo 4 del Convenio Marco de las Naciones } \\
\text { Unidas sobre Cambio Climático. } \\
\text { El artículo 14.1, literal del Convenio sobre } \\
\text { Diversidad Biológica. }\end{array}$ \\
\hline $\begin{array}{l}\text { 2) La aplicación de normas } \\
\text { consagradas en documentos } \\
\text { internacionales, conforme indican } \\
\text { las leyes aprobadas por el Congreso. }\end{array}$ & $\begin{array}{l}\text { Declaración de Río, que debe tenerse en cuenta } \\
\text { al estar relacionada en el numeral 1 del } \\
\text { artículo 1 de la Ley 99 de 1993. Respaldada } \\
\text { por las sentencias 348 de 2012, T-294 de 2014 y } \\
\text { T-660 de 2015. }\end{array}$ \\
\hline $\begin{array}{l}\text { 3) La referencia de documentos } \\
\text { externos que carecen de fuerza } \\
\text { vinculante, pero ofrecen pauta } \\
\text { hermenéutica. }\end{array}$ & $\begin{array}{l}\text { La Declaración de Estocolmo de 1972. } \\
\text { La Carta Mundial de la Naturaleza. } \\
\text { La Convención de Aarhus sobre el Acceso a la } \\
\text { Información,la Participación del Público en la } \\
\text { Toma de Decisiones y el Acceso a la Justicia de } \\
\text { Medio Ambiente de 1998. }\end{array}$ \\
\hline
\end{tabular}

Fuente: elaboración propia.

A partir del estudio de esta normatividad, la Corte concluyó que garantizar la participación ambiental implica tres grandes aspectos: 1) el acceso a la información, 2) la participación pública y deliberada de la comunidad y 3) la existencia de mecanismos administrativos y judiciales para la defensa de los anteriores contenidos normativos. Dentro de la garantía de este derecho, creó una subregla para incluir elementos procedimentales y sustanciales necesarios para que exista una real y efectiva participación, los cuales se deben materializar a través de las siguientes fases: a) convocatoria, b) información, c) consulta e iniciativa, d) concertación, e) decisión, f) gestión y g) fiscalización.

Desde estos criterios jurisprudenciales se analizó si era viable aplicarlos a la delimitación del páramo del Almorzadero, a partir de la caracterización realizada. Para ello se 
usaron los criterios establecidos en la sentencia T-292 de 2006 sobre precedente aplicable. En esta decisión, la Corte Constitucional determinó cuáles eran los elementos que deben confluir para considerar que un precedente es aplicable:

(i) En la ratio decidendi de la sentencia se encuentra una regla relacionada con el caso a resolver posteriormente; (ii) La ratio debió haber servido de base para solucionar un problema jurídico semejante, o a una cuestión constitucional semejante; (iii) Los hechos del caso o las normas juzgadas en la sentencia anterior deben ser semejantes o plantear un punto de derecho semejante al que debe resolverse posteriormente. (Sentencia T-292 de 2006, p. 45)

Con base en esto y habiendo determinado la ratio de la sentencia T-361 de 2017, que sirvió de base para solucionar el conflicto de la delimitación del páramo de Santurbán y que estos casos tienen hechos similares, se concluyó que era viable aplicarlo en la defensa de los derechos de las asociadas de Asomuarce.

\section{Derecho a la participación ambiental de las mujeres}

Las mujeres campesinas del Cerrito han forjado una lucha constante por ser escuchadas en la toma de decisiones en diversos ámbitos, tanto políticos como sociales, respecto a su territorio; por ello, plantearon la conformación de su asociación desde 2005. En este sentido, se reivindican como sujetos de especial protección por parte del Estado colombiano al reunir la condición de mujer y de mujer campesina. De allí se deriva su derecho a participar en la toma de decisiones ambientales y su exigibilidad a través de las acciones jurídicas. 
Para ello, encontramos la ley de la mujer rural, que en su artículo $2 .^{\circ}$ dispone que por mujer rural se debe entender "toda aquella que sin distingo de ninguna naturaleza e independientemente del lugar donde viva, su actividad productiva está relacionada directamente con lo rural, incluso si dicha actividad no es reconocida por los sistemas de información y medición del Estado o no es remunerada” (Ley 731 de 2002). También encontramos el artículo 14 de la Convención sobre la Eliminación de todas las Formas de Discriminación contra la Mujer (CEDAw), de 1979 según el cual los Estados: “Adoptarán todas las medidas apropiadas para eliminar la discriminación contra la mujer en las zonas rurales a fin de asegurar, en condiciones de igualdad entre hombres y mujeres, su participación en el desarrollo rural y en sus beneficios" (parte 3, art. 10). Y el principio 20 de la Declaración de Río de 1992, ya señalado.

Lo anterior obliga al Estado a implementar medidas afirmativas ${ }^{1}$ que garanticen plenamente el acceso en igualdad de condiciones de las mujeres campesinas a todos los espacios políticos, económicos y sociales de su territorio, en especial a participar en la toma de decisiones ambientales, por las implicaciones que estas conllevan en la vida de las mujeres. Por ello, asegurar y garantizar la participación activa de las mujeres en la adopción de decisiones ambientales se halla

1 Con la expresión medidas afirmativas se designan políticas o medidas dirigidas a favorecer a determinadas personas o grupos, ya sea con el fin de eliminar o reducir las desigualdades de tipo social, cultural o económico que los afectan, bien de lograr que los miembros de un grupo subrepresentado, usualmente un grupo que ha sido discriminado, tengan una mayor representación (sentencia C-371 de 2000). 
en sintonía con lo dispuesto en la Plataforma de Beijing, ${ }^{2}$ en la que se estableció como medida:

Facilitar y fomentar el acceso de la mujer a la información y la educación, inclusive en las esferas de la ciencia, la tecnología y la economía, promoviendo de ese modo sus conocimientos, aptitudes y oportunidades de participación en las decisiones relativas al medio ambiente. (onu, 1995, p. 182)

De allí que asegurar la participación de las mujeres cerritanas en el proceso de delimitación del páramo permitiría abrir un escenario para la promoción de la igualdad de género, entendida como la existencia de una igualdad de oportunidades y de derechos entre las mujeres y los hombres, en las esferas privada y pública, que les brinde y garantice la posibilidad de realizar la vida que deseen (Unesco, s. f.), y contribuir de esta manera en la consecución de una de las metas establecidas en los Objetivos de Desarrollo Sostenible, ${ }^{3}$ consistente en asegurar la participación plena y efectiva de las mujeres y la igualdad de oportunidades de liderazgo a todos los niveles decisorios en la vida política, económica y

2 La Declaración y la Plataforma de Beijing de 1995 es una agenda con visión de futuro para el empoderamiento de las mujeres. Todavía hoy en día continúa siendo la hoja de ruta y el marco de políticas internacional más exhaustivo para la acción, y la actual fuente de orientación e inspiración para lograr la igualdad de género y los derechos humanos de las mujeres y las niñas en todo el mundo.

3 Los Objetivos de Desarrollo Sostenible se gestaron en la Conferencia de las Naciones Unidas sobre el Desarrollo Sostenible, celebrada en Río de Janeiro, en 2012. El propósito era crear un conjunto de objetivos mundiales relacionados con los desafíos ambientales, políticos y económicos con que se enfrenta nuestro mundo. 
pública (Programa de la Naciones Unidas para el Desarro1lo, 2015). Por ello, la incorporación del enfoque de género en los procesos de participación para asuntos ambientales debe atender a la implementación de medidas afirmativas que garanticen mejores condiciones para que las mujeres puedan acceder a dichos espacios y contar con su plena participación. Con base en estas consideraciones, se propuso tener como fundamento de derecho de la acción jurídica la exigibilidad del derecho de las mujeres a participar en la toma de decisiones ambientales.

La acción de tutela interpuesta no tuvo como único fin la reversión del proceso de delimitación del páramo del Almorzadero, sino que iba acompañada de la intención de visibilizar una de las tantas situaciones de desigualdad de género que afrontan las mujeres campesinas en Colombia.

La invisibilización de las mujeres cerritanas como sujetos con poder decisorio en el proceso de delimitación tuvo fundamento en la falta de titularidad de la tierra, toda vez que los hombres tradicionalmente han tenido la posesión y fueron los primeros en ser llamados a los espacios de socialización. Lo anterior ocasionó que las preocupaciones de las cerritanas quedaran subrepresentadas en las de los hombres, como válidos interlocutores de las familias parameras, desconociendo los lazos de producción y protección de las campesinas con el territorio.

Para que el Gobierno colombiano cumpla el Objetivo de Desarrollo Sostenible 5, puntualmente en el caso de los procesos de delimitación de páramos, debe permitirse el acceso de las mujeres a los espacios de concertación, reconociendo su liderazgo; capacitarlas en asuntos ambientales; incentivar sus procesos de producción, y asesorarlas en asuntos legales. 
Este último punto es fundamental para el reconocimiento de los derechos de las mujeres como propietarias de la tierra y, así, lograr su participación plena en los programas de sustitución y reconversión de los procesos de delimitación.

\section{Interposición de la acción de tutela}

En atención a los análisis realizados sobre la información recolectada en el taller con las mujeres, la revisión de los documentos y soportes allegados por el MADs y los estudios acerca de la normatividad y los pronunciamientos jurisprudenciales, se pudo concluir que no había sido garantizado el derecho a la participación de las comunidades afectadas por la delimitación del páramo, mucho menos las mujeres como sujeto diferenciado. En ese sentido, se encontró jurídicamente posible interponer una acción de tutela que ordenara al MADs adelantar un proceso participativo de delimitación en el que las mujeres fueran partícipes en cuanto mujeres, ya como individuos, ya como organización. Se resalta que, a la fecha de presentación de este documento, la tutela ya fue incoada; sin embargo, todavía no hay fallo de primera instancia. A continuación, se sintetizan las consideraciones hechas por el semillero para fundamentar la acción:

\section{Legitimación}

La Asociación, en nombre de sus asociadas, en cuanto mujeres campesinas, principales afectadas por la delimitación unilateral realizada por el MADs, cuenta con la legitimidad y el interés para interponer la acción de tutela, en la medida en que no fueron llamadas a ser partícipes en el proceso de delimitación del páramo del Almorzadero, ni en su dimensión asociativa como mujeres campesinas habitantes del 
páramo, ni en su dimensión individual, y teniendo en cuenta que la delimitación de los páramos, más que una decisión técnico-científica que se impone, es una decisión política que incumbe a las comunidades habitantes del espacio que se va a delimitar y que, por lo tanto, exige de su participación activa bajo la óptica de la participación ambiental como derecho fundamental y las reglas establecidas por la jurisprudencia constitucional, en concreto la sentencia T-361 de 2017.

Tuvimos en consideración que las personas jurídicas, de la misma forma que las naturales, están habilitadas para solicitar el amparo de sus derechos fundamentales vulnerados o amenazados, pues el artículo 86 superior no distingue la calidad de la persona que puede interponer una acción de tutela, al tiempo que la jurisprudencia constitucional ha reconocido ciertos derechos fundamentales en cabeza de las personas jurídicas, como ocurrió en la sentencia T-361 de 2017:

En el último evento, la persona jurídica referida podría ser titular directa de los derechos del debido proceso, de petición y de acceso a la información. Lo propio sucede con la participación, empero esa titularidad se ejerce de manera indirecta, puesto que se pretende salvaguardar la intervención de las personas naturales que componen el ente moral y que podrían verse afectadas con la decisión de delimitar el páramo de Santurbán. (p. 74)

Sin embargo, ello no obsta para que a través de la tutela, además de los derechos de las asociaciones, puedan tutelarse de manera indirecta los derechos de sus asociados. Esta acción se dirigió contra del mads, la autoridad 
encargada de expedir los actos administrativos delimitadores de los páramos del país, por mandato del artículo 202 de la Ley 1450 de 2011 y que, en consecuencia, expidió la Resolución 152 del 31 de enero de 2018, en perjuicio del derecho a la participación en materia ambiental de las accionantes y, en general, de las comunidades habitantes del páramo.

\section{Subsidiariedad e inmediatez}

Teniendo en cuenta que la acción jurídica va dirigida a controvertir un acto administrativo de carácter general, frente al cual podría, en principio, incoarse un medio de control como el de nulidad simple, esta acción de tutela cobra especial procedencia como mecanismo principal y no transitorio, en la medida en que se configuran las circunstancias previstas por la Corte en la sentencia su-355 de 2015, a saber: la falta de idoneidad de los medios existentes en la jurisdicción de lo contencioso administrativo y el hecho de que las herramientas procesales consagradas en la Ley 1437 de 2011 no proporcionan una protección oportuna e integral de los derechos vulnerados. Resulta necesario para tales efectos tener presente lo señalado en sentencia T-361 de 2017:

De un lado, las demandas de amparo de derechos fundamentales son procedentes cuando: i) la persona afectada carece de medio ordinario para defender esos principios, dado que no tiene legitimación para cuestionar esa clase decisiones de la administración, o el asunto objeto de debate es de naturaleza constitucional; y ii) la aplicación del acto administrativo general amenaza o vulnera los derechos fundamentales de un individuo. De otro lado, se adoptará la misma decisión, en el evento en que las determinaciones 
abstractas de las autoridades causen efectos dañinos sobre los derechos fundamentales de las personas, perjuicios que son irremediables. En esos dos eventos, esta Corporación tiene la potestad de disponer la inaplicación o la pérdida de ejecutoria del acto objetivo proferido por parte de la administración. (Sección Subsidiariedad, 8.3.3)

En ese orden de ideas, la Resolución 152 de 2018, como acto administrativo de carácter general, es susceptible de ser cuestionada en sede de tutela, puesto que su expedición implicó la vulneración del derecho fundamental a la participación ambiental en la delimitación del páramo del Almorzadero, es decir, el asunto objeto de debate es de naturaleza constitucional, lo cual "supone la ausencia de idoneidad del medio de control de nulidad simple para proteger ese principio en su dimensión subjetiva" (sentencia T-361 de 2017, Sección Subsidiariedad, 8.3.3), puesto que por su naturaleza se limita a verificar la congruencia entre el mandato de la administración con la ley, y no a garantizar derechos fundamentales como el de la participación ambiental en relación con la delimitación los páramos, empezando porque este último no tiene desarrollo legal, según lo determinó la Corte en la sentencia T-361 de 2017, respecto de la resolución que delimitó el páramo de Santurbán.

$\mathrm{E}$ lacto administrativo en discusión fue proferido el 31 de enero de 2018, de lo cual se extrae que nos encontrábamos dentro de un plazo razonable desde dicho momento hasta el momento de interposición de la acción de amparo. Téngase en cuenta que se habían interpuesto los derechos de petición necesarios para recolectar la información que pudiera sustentar probatoriamente la acción, así como analizar la información 
proporcionada por el MADS y los conceptos jurídicos utilizados. Finalmente, frente al requisito de inmediatez es claro que la vulneración del derecho a la participación ambiental es permanente en el tiempo, actual y manifiesta.

\section{Conclusiones}

El Semillero Vida, Ciencia y Derechos Humanos se encuentra frente a un acompañamiento no terminado, en la medida en que la tutela aún no ha sido decidida en primera instancia y la garantía de la participación de las mujeres no se restringe a la discusión sobre la delimitación del páramo, sino que se refiere al escenario posterior a la delimitación y a las actividades que sustituirán las tradicionalmente desarrolladas, pero contrarias con la pervivencia del ecosistema. Sin embargo, ello no es óbice para que del proceso adelantado se puedan sacar las siguientes conclusiones:

1. Existe un marco normativo nacional e internacional respecto a la participación efectiva en la toma de decisiones ambientales que debe garantizarse a las mujeres campesinas y las mujeres en general, máxime si afectan el territorio que habitan. Esto debido a que tradicionalmente la participación de las mujeres campesinas se ha visto limitada, dada la desigualdad de género basada en el rol que deben desempeñar las mujeres en los espacios políticos, económicos y sociales de la comunidad. Así, han sido relegadas a actividades domésticas y de cuidado, lo que implica que sean subrepresentadas por los hombres en los espacios de participación y decisión, y que sus propuestas sean invisibilizadas. 
2. El derecho a la participación en la toma de decisiones ambientales y, más específicamente, este derecho en los procesos de delimitación de páramos fue decantado por la jurisprudencia constitucional como un derecho fundamental que existe en virtud del principio democrático que irradia al Estado colombiano. Para ello, la Corte Constitucional estableció una serie de reglas y subreglas que deben ser atendidas por el Gobierno en los distintos procesos de delimitación. Sin embargo, en este análisis realizado por la Corte, principalmente en la sentencia T-361 de 2017, se omitió contemplar de manera transversal los derechos de las mujeres, especialmente el derecho a la participación.

3. En el caso estudiado pudo observarse que las mujeres cerritanas y Asomuarce no fueron llamadas a ser partícipes en el proceso de delimitación del páramo del Almorzadero, ni como ente colectivo que desde 2005 trabaja por la defensa del páramo y de las mujeres campesinas, ni como mujeres individualmente entendidas. Entonces, a partir de las aseveraciones hechas por el MADs, frente al hecho de que sí se garantizó el derecho a la participación de las comunidades y los fundamentos de estas aseveraciones que fueron proporcionados, se puede concluir que, desde la perspectiva del MADs, el derecho a la participación se limitó a la mera socialización de las decisiones ya tomadas, lo cual desconoce el precedente constitucional frente a la participación en los procesos de delimitación de páramos. El MADs pudo implementar medidas como la invitación directa a las mujeres campesinas a los espacios de información, la concertación de una agenda individual para las mujeres campesinas y hasta la posibilidad de contar con 
espacios de atención para los niños, niñas y adolescentes que están bajo su cuidado; sin embargo, la situación particular de las mujeres se obvió en este proceso.

4. Se determinó que la acción jurídica pertinente para garantizar y proteger el derecho a la participación de las mujeres cerritanas en el proceso de delimitación del páramo del Almorzadero era la acción de tutela que, a nuestro parecer, debe ser fallada bajo la ratio decidendi de la sentencia T-361 de 2017.

\section{Referencias}

Asociación de Mujeres Campesinas y Artesanas de Cerrito (Asomuarce). (2018, 20 de mayo). Relatoría. (Semillero Vida, Ciencia y Derechos Humanos).

Constitución Política de Colombia. (1991). Artículo 2, artículo 7. Recuperado de http://www.secretariasenado.gov.co/ senado/basedoc/constitucion_politica_1991.html

Convención sobre la eliminación de todas las Formas de Discriminación Contra la Mujer (cEDAw). (1979, 18 de diciembre). Parte 3, artículo 10. Recuperado de http://www. un.org/womenwatch/daw/cedaw/text/sconvention.html

Escobar, J. y Bonilla-Jiménez, F. I. (2009). Grupos focales: Una guía conceptual y metodológica. Cuadernos Hispanoamericanos de Psicologia, 9(1), 51-67. Recuperado de http://biblioteca.udgvirtual.udg.mx/jspui/ bitstream/123456789/957/1/Gupos \%20focales \%20 una $\% 20$ gu $\%$ C3 \%ADa $\% 20$ conceptual $\% 20$ y $\% 20$ metodol\%C3\%B3gica.pdf

Instituto de Investigación de Recursos Biológicos Alexander von Humboldt. (2011). El gran libro de los páramos. 
Bogotá: Autor. Recuperado de http://hdl.handle.net/20. $500.11761 / 31389$

Knox, J. (2016). Prólogo. En Derechos humanos y medio ambiente: Avances y desafios para el desarrollo sostenible (pp. 3-4). Montevideo, Uruguay. Recuperado de http://www. latinamerica.undp.org/content/rblac/es/home/library/ poverty/-derechos-humanos-y-medio-ambiente-avancesy-desafios-para-el-de.html

Ley 1450 de 2011 (16 de junio), por la cual se expide el Plan Nacional de Desarrollo 2010-2014. Recuperado de http://www.secretariasenado.gov.co/senado/basedoc/ ley_1450_2011.html

Ley 731 de 2002 (16 de enero), por la cual se dictan normas para favorecer a las mujeres rurales. Recuperado de http://www.secretariasenado.gov.co/senado/basedoc/ ley_0731_2002.html

Martínez Carazo, P. (2006). El método de estudio de caso: Estrategia metodológica de la investigación científica. Pensamiento E Gestión. Recuperado de http://www.redalyc.org/articulo.oa?id=64602005

Ministerio de Ambiente y Desarrollo Sostenible (mads). (2018,31 de enero). Resolución 0152. Bogotá, Colombia. Organización de las Naciones Unidas (onu). (1992, junio). Declaración de Río sobre el Medio Ambiente y el Desarrollo. Recuperado de http://www.un.org/spanish/esa/sustdev/ agenda21/riodeclaration.htm

Organización de las Naciones Unidas (onu). (1995). Declaración y plataforma de acción de Beijing. Recuperado de http://beijing20.unwomen.org/ /media/headquarters/ attachments/sections/csw/bpa_s_final_web.pdf 
Organización de las Naciones Unidas para la Educación, la Ciencia y la Cultura (Unesco). (s. f.). Igualdad de género. Recuperado https://es.unesco.org/creativity/sites/creativity/files/digital-library/cdis/Iguldad\%20de\%20genero.pdf Ospina, D. R. y Rodríguez, C. (2011). Guía divulgativa de criterios para la delimitación de páramos de Colombia. Bogotá: Instituto Humboldt. Recuperado de http://www. humboldt.org.co/images/Atlas \%20de \%20paramos/ Guia_delimitacion_paramos.pdf

Programa de la Naciones Unidas para el Desarrollo. (2015, 25 de septiembre). Objetivos de Desarrollo Sostenible. Recuperado de https://www.undp.org/content/undp/es/ home/sustainable-development-goals/goal-5-genderequality.html

Quecedo, R. y Castaño, C. (2002). Introducción a la metodología de investigación cualitativa. Psicodidáctica (14), 5-39. Recuperado de https://www.redalyc.org/pdf/175 /17501402.pdf

Sentencia C-150 de 2015 (8 de abril) (mp Mauricio González Cuervo). Recuperado de http://www.corteconstitucional. gov.co/RELATORIA/2015/C-150-15.htm

Sentencia C-179 de 2002 (12 de marzo) (м P Marco Gerardo

Monroy). Recuperado de http://www.corteconstitucional. gov.co/relatoria/2002/C-179-02.htm

Sentencia C-499 de 2015 (5 de agosto) (MP Mauricio González Cuervo). Recuperado de http://www.corteconstitucional. gov.co/relatoria/2015/C-499-15.htm

Sentencia su-355/15 (11 de junio) (MP Mauricio González Cuervo). Recuperado de http://www.corteconstitucional. gov.co/relatoria/2015/su355-15.htm 
Sentencia T-065 de 2015 (13 de febrero) (mp María Victoria Calle Correa). Recuperado de http://www.corteconstitucional.gov.co/relatoria/2015/T-065-15.htm

Sentencia T-292 de 2006 (6 de abril) (mp Manuel Cepeda). Recuperado de http://www.corteconstitucional.gov.co/ relatoria/2006/t-292-06.htm

Sentencia T-361 de 2017 (30 de mayo) (mp Alberto Rojas Ríos). Recuperado de http://www.corteconstitucional. gov.co/relatoria/2017/t-361-17.htm 
Este libro fue compuesto en caracteres Adobe Caslon

Pro 11,2 puntos, impreso en noviembre de 2019, en Bogotá, D. C., Colombia

Xpress. Estudio Gráfico y Digital SAS 
Próximos a cumplir el primer quinquenio de los quince años previstos para alcanzar el máximo resultado en la realización de los Objetivos de Desarrollo Sostenible (ODS), la Universidad del Rosario, en cabeza del Observatorio Legislativo y el Grupo de Investigación en Derechos Humanos, en asociación con la Fundación Hanns Seidel, ha brindado el espacio propicio de investigación para los estudiantes interesados en reflexionar, discutir y proponer trabajos académicos relacionados con los ODS. Así, este libro recoge las ponencias de los estudiantes ganadores del Ix Concurso de Semilleros de Investigación, en procura de fomentar espacios académicos de fortalecimiento de la democracia, la institucionalidad y los derechos humanos, dentro de los cuales este concurso se destaca no solo por su perdurabilidad en el tiempo, al atender temas coyunturales para el país, sino por dar valor a la investigación como herramienta de cambio social y como instrumento pedagógico de enseñanza que debe fomentarse en la educación superior.
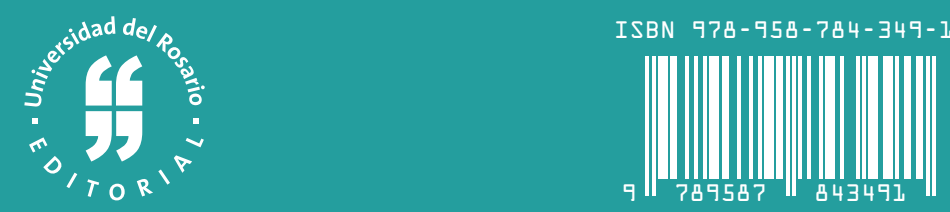